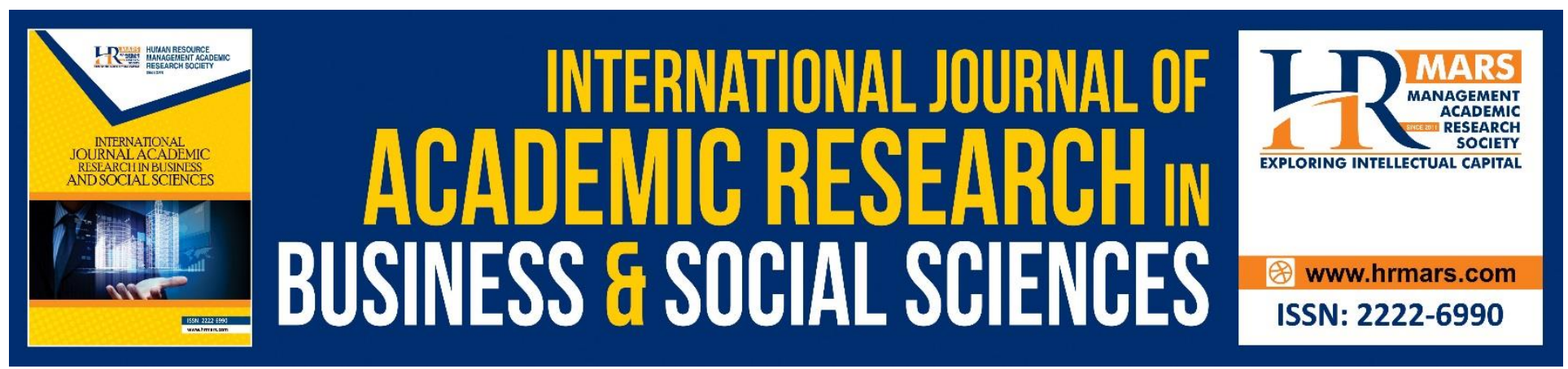

\title{
1MDB: Corporate Governance Going Berserk? Part I
}

\author{
Azham Md. Ali
}

To Link this Article: http://dx.doi.org/10.6007/IJARBSS/v8-i12/5361

DOI: $10.6007 /$ IJARBSS/v8-i12/5361

Received: 02 Nov 2018, Revised: 13 Dec 2018, Accepted: 21 Dec 2018

Published Online: 28 Dec 2018

In-Text Citation: (Ali, 2018)

To Cite this Article: Ali, A. M. (2018). 1MDB: Corporate Governance Going Berserk? Part I. International Journal of Academic Research in Business and Social Sciences, 8(12), 1861-1946.

Copyright: (C) 2018 The Author(s)

Published by Human Resource Management Academic Research Society (www.hrmars.com)

This article is published under the Creative Commons Attribution (CC BY 4.0) license. Anyone may reproduce, distribute, translate and create derivative works of this article (for both commercial and non-commercial purposes), subject to full attribution to the original publication and authors. The full terms of this license may be seen at: http://creativecommons.org/licences/by/4.0/legalcode

Vol. 8, No. 12, 2018, Pg. 1861 - 1946

http://hrmars.com/index.php/pages/detail/IJARBSS

JOURNAL HOMEPAGE

Full Terms \& Conditions of access and use can be found at http://hrmars.com/index.php/pages/detail/publication-ethics 


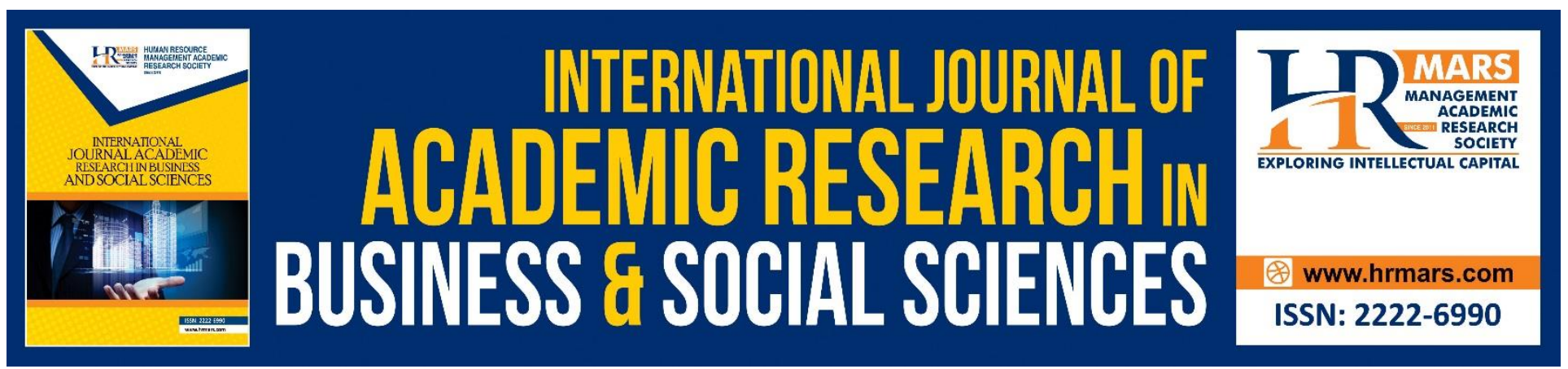

\title{
1MDB: \\ CORPORATE GOVERNANCE GOING BERSERK? PART I
}

\author{
Azham Md. Ali \\ Department of Accounting and Finance, Faculty of Management and Economics \\ Universiti Pendidikan Sultan Idris, 35900 Tanjong Malim Perak Malaysia \\ Email: azham@fpe.upsi.edu.my
}

\begin{abstract}
The Part I of two parts of a case study on 1MDB's corporate governance going berserk? dwells on three areas: the definition and purposes of corporate governance; the questions various local parties have raised on 1MDB's operations and related matters; and, the answers handed down by the 1MDB and other related parties. For the last one the answers come in three ways: in the form of words, efforts in obstructing justice and various tactics in intimidating parties from inside and outside the country. All this in Part 1 are in contrast to Part II which is concerned with only two areas: first, weak corporate governance and the like or fraud to describe the goings on in and around 1MDB; and, second, questions looking for answers which readers of both Part I and Part II of the case study may want to answer.
\end{abstract}

Keywords: 1MDB, Corporate Governance, Questions, Answers

\section{Introduction}

Whereas the 20th century might be viewed as the age of management, the early 21st century is predicted to be more focused on governance. Both terms address control of corporations but governance has always required an examination of underlying purpose and legitimacy (McRitchie, 2019). Corporate governance is the system of rules, practices and processes by which a company is directed and controlled. Corporate governance essentially involves balancing the interests of a company's many stakeholders, such as shareholders, management, customers, suppliers, financiers, government and the community (Chen, 2018). The fundamental objective of corporate governance is to enhance shareholders' value and protect the interests of other stakeholders by improving the corporate performance and accountability... The overall endeavour of the board should be to take the organisation forward so as to maximize long term value and shareholders' wealth (Business Portal of India, 2019). The purpose of corporate governance is to facilitate effective, entrepreneurial and prudent management that can deliver the long-term success of the company.... Corporate governance is therefore about what the board of a company does and how it sets the values of the company, and it is to be distinguished from the day to day 
operational management of the company by full-time executives (Financial Reporting Council, 2016).

There are varying definitions of corporate governance, many of which touch on aspects of the concept but fall short of the mark. With that said, to define corporate governance in a nutshell is not easy but, put very simply, "good governance is good business". More specifically, corporate governance is the framework that allows for a company to be directed and controlled, and ensures that those who direct and control the company do so accountably. This framework of policies, procedures and practices (and related systems) allows a business to operate effectively, responsively, ethically and compliantly, while controlling risk. In many respects, it is about positioning the business to be sustainable. This framework is "shaped" by informed, objective and aware people (typically directors and officers) who are in a position to develop effective strategies and to have real influence over the business, and who act with care and diligence.... To have policies and procedures in place to ensure accuracy, consistency and responsiveness to key stakeholders (for example, customers, shareholders, regulators), to facilitate productive and efficient work practices, to guide, develop and monitor people's performance, to capture, interpret and report accurate and relevant data, and to manage the risks inherent to the company's operations, and for these to be aligned with the strategic direction set for the business, are all aspects of "good governance". In essence, it is through good governance that sustained returns and ultimately, increased value can be delivered to the shareholders or owners of a business and which can help to attract investment if required (Douglas, 2010).

Corporate governance is the way a corporation polices itself. In short, it is a method of governing the company like a sovereign state, instating its own customs, policies and laws to its employees from the highest to the lowest levels. Corporate governance is intended to increase the accountability of your company and to avoid massive disasters before they occur. Failed energy giant Enron, and its bankrupt employees and shareholders, is a prime argument for the importance of solid corporate governance (Sun, 2019).

The basic purpose of corporate governance is to monitor those parties within a company which control the resources owned by investors. The primary objective of sound corporate governance is to contribute to improved corporate performance and accountability in creating long-term shareholder value (Kaplan Financial, 2013).

For each of the quotations above coming from different sources is concerned with either one or both aspects of corporate governance: the definition and the purposes. The sources from which the quotations come from are easily found through the google search of the internet. And easily too one can find so many other sources saying this and that on both items. What is not easy however is to find these definitions and purposes of corporate governance translated into real world practices considering the presence of numerous nasty examples around the world that show that corporate governance is nowhere to be found when one is very much in need of it! 
1MDB appears to be such an example - or perhaps nothing could be further from the truth since $1 \mathrm{MDB}$ is much, much more sinister than the case of corporate governance going berserk?

In attempting to get the full advantage of what is presented in the present case study on 1MDB's corporate governance, readers are advised to read beforehand the background piece plus three case studies on 1MDB's specific topics written by the same author. Two of these including the background piece were published in late 2015 while the other two in early 2016. All are available online and can be easily accessed through the author's google scholar account or even google search engine.

In addition to the author's prior works on $1 \mathrm{MDB}$, there are of course other materials which readers for the present case study may want to peruse. In particular over what happened in the $1 M D B^{\prime} s$ early years, the notable sources include:

- T'ganu Investment Authority to raise RM5b from capital markets (May 18, 2009)

- Cover Story: Terengganu's right royal achievement (May 24, 2009)

- Cover Story: 'TIA's role complementary to Khazanah's' (May 24, 2009)

- Cover Story: TIA setting a precedent (May 24, 2009)

- Cover Story: 'We will forge strategic global partnerships to spur FDIs' (December 13, 2009)

- Cover Story: Time of reckoning for 1 MDB (December 13, 2009)

- Shahrol: Government did not inject cash into 1MDB (October 12, 2010)

- 1MDB: Giant ponzi scheme or strategic investment fund? (March 26, 2013)

- Khazanah Nasional vs 1MDB (April 3, 2013)

- Najib: Govt will repay 1 MDB unit's US\$3b debt if it can't (March 17, 2015)

- Terengganu Investment Authority's RM500m start-up capital 'untrue' - PM Najib (May 28, 2015)

- Start-up capital for TIA was RM1m, not RM500m, says Najib (May 29, 2015)

- Dr M says Jho Low persuaded Najib to form 1MDB (June 12, 2015)

- Cover Story: He did no wrong? (April 28, 2016)

Note that with the exception of the material that came out in early April 2013 that come from www.kinibiz.com, the rest come from www.theedgemarkets.com with the first five listed have the byline The Editor with the name TheEdge mentioned below it.

As for the detailed background materials on various aspects of 1MDB's business operations over the years, these may be found in numerous materials found on line. Such materials include the following that come from www.theedgemarkets.com with the exception of the first three that come from www.kinibiz.com and the one in April 2015 that come from www.theedgereview.com:

- 1 MDB: Giant ponzi scheme or strategic investment fund? (March 26, 2013) 
INTERNATIONAL JOURNAL OF ACADEMIC RESEARCH IN BUSINESS AND SOCIAL SCIENCES

Vol. 8, No. 12, Dec, 2018, E-ISSN: 2222-6990 @ 2018 HRMARS

- $\quad$ Do we need $1 M D B$ at all? (March 5, 2014)

- 1MDB: A disaster unfolding before our very eyes (April 23, 2014)

- Story of the years: $1 \mathrm{MDB}$ - no more the elephant in the room (January 16, 2015)

- The twists \& turns of $1 \mathrm{MDB}^{\prime}$ 's first US\$1 bil (March 26, 2015)

- The 1MDB: Tragedy or farce? (April 9, 2015)

- Malaysia's Najib feels the heat as state-owned 1MDB melts down (July 22, 2015)

- Story of the year: 1MDB The Story of 2015 (January 5, 2016)

- Cover Story: He did no wrong? (April 28, 2016)

- Cover Story: The PAC report and what The Edge previously reported (April 28, 2016)

- 1MDB: The inside story of the world's biggest financial scandal (July 29, 2016)

- Timeline of Jho Low's corporate and financial wheeling and dealing using US\$1.83 billion that belonged to 1MDB (April 10, 2017)

- Story of the Year: 1MDB Fire reduced to embers (January 1,2018 )

- Timeline: The 1MDB scandal that led to the arrest of Najib (July 3, 2018)

And finally while the concern is still on getting as much information as possible on 1MDB from some of the most accessible and well written sources everywhere to add in to all that readers shall find in the present lengthy case study, readers may want to check out the following volumes that came out in the second half of 2018 where two are written by Malaysians themselves and the other two by highly credible parties from overseas:

- $1 M D B$ : The Scandal That Brought Down The Government by P. Gunasegaram and Kinibiz

- Billion Dollar Whale: The Man Who Fooled Wall Street, Hollywood, and the World by Tom Wright and Bradley Hope

- The Sarawak Report: The Inside Story of the 1MDB Exposé by Clare Rewcastle Brown

- From BMF to 1MDB: A Criminological and Sociological Discussion by Teh Yik Koon

Once readers gain some sort of familiarity with all which may be considered significant regarding the $1 \mathrm{MDB}$ coming from the various sources mentioned above, it is time to take note of a number of matters of interest concerning the present case study. First for the most part, the case study is concerned with the goings on in 1MDB's business practices and related matters up to the country's fourteenth general election (GE14) on May 9, 2018. That said, most of the materials cited revolve upon the years 2015 and 2016. This is perhaps unavoidable since more write ups on the 1MDB appear to have come out in those two years compared to the years before or ever since. Second, the present case study (comprising of Part I and Part II) is one of two or possibly three case studies concerning 1MDB's corporate governance and the bigger context that it is in. Third and the final item of interest to take note of is the fact that, due to some constraints, complete triangulations of sources have failed to be executed for many items mentioned in the case study. 
But the lack of complete triangulations of sources is not much to worry about for in most parts the author who has been following the story of 1MDB since 2013 is humbly and honestly believed that what is presented is credible since in just about every single case the items included in the present case study come from the highly regarded news or business portals The Edge and Malaysiakini or websites of highly regarded personalities such as the former prime minister Tun Dr. Mahathir Mohamad and Lim Kit Siang. Also, and this should be worth noting, all the time during the search for materials to be followed by the writing process the author continues to apply his detailed knowledge of the 1MDB goings on over the years in judging the credibility of items being perused. Needless to say, items that finally get to be included in the present case study are those considered to be highly credible.

With all that said, for the rest of the case study, in the listing out of the so very many samples of headings of news reports such as those above, readers are safe to assume that almost all of these headings come from theedgemarkets.com while the rest from the malaysiakini.com - in cases where there is no detailing made as to their respective sources. Hence, in cases where readers are interested to locate the whole of news reports whose headings are listed out this may easily be done by writing down (or copying and pasting) the headings in either the google search engine or the search engines found in www.theedgemarkets.com or www.malaysiakini.com. In fact, by doing the latter, the concerned readers follow the manner that these materials were first located by the author himself using certain key words of concern.

All in all, it has been quite a ride for the author from August 2018 to late January 2019 in completing the present case study. But if this effort of his together with the efforts of so many others from inside and outside Malaysia can get everyone closer to the truth regarding the 1MDB it should all be worth it. And as to why the truth about the $1 \mathrm{MDB}$ is so very important to so many is simply put at a press conference on July 20, 2016 at the Department of Justice in Washington by the then US attorney general Loretta E. Lynch.

Accompanied by other top US officials, she told reporters the Justice Department had filed lawsuits on Wednesday to seize over US\$1 billion (about RM4.05 billion) in assets that it said were the result of US\$3.5 billion that was misappropriated from 1MDB. She was also quoted to say ("United States seeks to recover", 2016):

The Department of Justice will not allow the American financial system to be used as a conduit for corruption. With this action, we are seeking to forfeit and recover funds that were intended to grow the Malaysian economy and support the Malaysian people. Instead, they were stolen, laundered through American financial institutions and used to enrich a few officials and their associates. Corrupt officials around the world should make no mistake that we will be relentless in our efforts to deny them the proceeds of their crimes. (Emphasis added.) 
In other words, the truth is crucial so that the bitter lessons of 1MDB learnt today can assist Malaysian of the present and the future to try to avoid any other 1MDBs from ever taking place again - for surely at all time public funds are for the public to profit from instead of what was the case with the $1 \mathrm{MDB}$ ? And such lessons may be good too for the rest of the world in particular the developing and poor countries with nowhere to go but down due to the presence of their ever powerful corrupt leaders who like to pretend of course that the people are their priority.

The present case study is the one way needed in an attempt to gain lessons to be learnt from the 1MDB debilitating saga by students in governance and accounting classes in the higher institutions of learning in Malaysia if not the world over. And this would be just like the other cases written so far (and also in the coming years) on the subject of 1MDB by the author. With these students possibly occupying the seats of decision making in the future, the strong foundation on the need for good governance and credible accounting and auditing has to be planted today.

Also, it should never be forgotten that the case studies and this very one in particular comprising of Part I and Part II on 1MDB's corporate governance should be able to get those unable to see the various wrong doings in $1 \mathrm{MDB}$ to finally get to see all the pieces together to perhaps to never again to be in denial of the $1 \mathrm{MDB}^{\prime}$ s revolting truth! In case that fails to take place for after all "people believe what they want to believe" the author simply wants to know that he has done his best on behalf of the voiceless who have nevertheless suffer one way or another due to the corruption in $1 \mathrm{MDB}$ and similar other cases taking place over the years in the beloved Malaysia.

The next section delineates the questions raised by various parties on 1MDB operations. These questions may cover a variety of 1MDB's activities or just one aspect of the 1MDB operations. For the former, a litany of questions may be grouped under one of the three different categories possible: media, politicians and laymen. And each list of questions is presented in the exact manner they were originally presented by those who produce them. In other words, if certain words are made bold or there is no spacing use to separate the different items in the list, such would be the cases when they are reproduced for the present case study. Following the section on questions, there is the section on the answers provided by the concerned parties. Apparently, there is more than one type of answers and each seems to have failed to get anyone to be any closer to the truth! Together with the introduction, the next section on questions which is followed by the section on answers form Part I of the case study.

With the first three sections forming Part I of the case study out of the way, the penultimate section that follows gives focus on what various parties claim to be the truth about 1MDB - fraud through and through or nothing more than a matter of corporate governance and the like that went wrong with no malice whatsoever behind it all. And the final section that comes right after is concerned with the decision that readers of the case have to make: to agree with either one of the two stances discussed in the previous section or make up one's mind for something else. Both the penultimate and final sections form Part II of the case study. 


\section{The Questions...}

The questions raised on 1MDB may be found in two types of works. One is in the form of a listing of groups of questions covering a wide variety of issues. As for the other type of works, there would just be a handful of questions covering some specific issue(s) of concern since the focus for the whole piece is not quite to raise questions after questions like the first type of works but instead to give description of the specific issue(s) of concern in some details.

Regarding the former, each of the chosen write ups has a listing of numerous questions covering more than a few areas of concern. Each write up may also come under one of three categories of parties who produce them: media; politicians; or, laymen. For the first category, they are represented by P. Gunasegaram and the newspaper The Edge Malaysia Weekly. For politicians, Lim Kit Siang, the former prime minister Tun Dr. Mahathir Mohamad and Tony Pua. And finally for laymen they are represented by one T. K. Chua.

Specifically, there are four lists of questions from P. Gunasegaram the founding editor of business news and views portal KiniBiz and two from the newspaper The Edge Malaysia Weekly. Note that when it concerns the latter one of the two has the barrage of questions come not in the form of a list but instead in one full paragraph. As for the politician category of sources, it is comprised of two lists of questions from each Lim Kit Siang and Tun Dr. Mahathir Mohamad and one from Tony Pua. When it concerns the very last category of laymen there are two lists of questions coming from one single party T. K. Chua.

As for the type of works focusing on specific issues with limited number of questions raised, four have been selected for the present study: Air Itam Penang land deal; Murabahah notes; types of RM15.4 billion 1MDB investments; and, assets backing for some RM27bil of the RM42bil loans taken up by $1 \mathrm{MDB}$. Readers who may be interested to locate for more topics may want to see the following: RM2bil loan from Ananda (Sharmila, 2015); Petro Saudi, Good Star, etc. of the 1MDB early years (The Edge Malaysia, 2015a); Cayman Islands investments, Aabar's investments/deposits, financial expenditures (Zachariah, 2015a); Goldman fees (Blemin, 2014a); 1MDB insolvency (Pua, 2015a); and, IPPs acquisition at high price (Barrock, 2013a).

In the rest of the section, the two types of works are covered with the one covering specific topics is delineated first to be followed by the other types of works.

\subsection{Questions for Specific Topics}

Out of so many around the four selected are: 1MDB RM27 billion disappeared funds; Air Itam Penang; murabahah notes; and, 1MDB's RM15.4b is cash or 'units'.

\subsubsection{MDB's RM27 billion Disappeared Funds and Cayman Islands Investments}

In April 2015, in his blog posting Tun Dr. Mahathir Mohamad claimed that he could not account for assets backing for some RM27bil of the RM42bil loans taken up by 1MDB (Mahathir, 2015a). Thus, with just RM 14.7 billion asset purchases ranging from power plants to land for property development totaled up, he asked the question: "Where is the rest of the money?" It is notable that right after raising that question, Tun in the very next line talks about 1MDB's Cayman Islands 
investments - perhaps hinting at possible corruption and theft of the concerned 1MDB's funds? As he put it:

26. A certain amount was registered in the Cayman Islands. What was the money used for? What was brought back to Malaysia? What was brought back and deposited in a Swiss bank in Singapore? Why? Where was the money brought back from? Why is this money not used to pay the RM2 billion interest? Why did Bank Negara allow the first tranche to be repatriated to Malaysia and not the second tranche? Now the Swiss bank has told the Singapore authorities that the document [which 1MDB chief executive officer Arul Kanda Kandasamy had supplied to some parties, relating to the accounts for its subsidiary, Brazen Sky Limited, in Singapore - in short these documents are nothing more than "false bank statements" of the concern bank accounts] did not originate from them and does not represent a true account of the assets of $1 \mathrm{MDB}$. So where is the money said to be registered in the Cayman Islands and is now brought back?

Note also that in this very blog posting of Tun Mahathir which is numbered 100 and with the title simply $1 \mathrm{MDB}$, early on in the third paragraph the following is mentioned:

3. Governments can lose money through bad investments. We would know where the money is lost. But when huge sums of money disappear, then those entrusted with its management must answer for the disappearance. Disappearance is different from just losing. Disappearance is about money lost which cannot be traced. This can be because of corruption or theft.

Related to this in the final paragraph of the posting, Tun without mincing his words had made the following devastating conclusion: "29. It is this disappearance of a huge amount of borrowed money by $1 M D B$ and the inability to answer questions regarding what happened to the funds that disqualifies Najib from being Prime Minister of Malaysia."

\subsubsection{Air Itam Penang}

The IMDB had bought the piece of land in Air Itam Penang Itam in two deals on April 29, 2013, six days before the May 5, 2013 general election, and in a third and final deal on Sept 23, 2013. In September 2014, as found in The Malaysian Insider, none other than the then Penang chief minister Lim Guan Eng who raised the following questions (Sue-Chern, 2014a): "Why was the purchase price at RM1.38 billion, 95\% higher than what some of the land was valued at, just two years earlier in December 2011? What would be the benefit to 1MDB and finally to the people of Malaysia that owns $1 \mathrm{MDB}$ ?" And since the price paid was exhorbitant he next was reported to have inquired on the federal government's promise to build 9,999 units of public and affordable housing via $1 \mathrm{MDB}$. He claimed that the $1 \mathrm{MDB}$ may face net losses of at least RM1.5 billion by building the homes. Furthermore, he was reported to have said that even if $1 M D B$ were to fail in keeping the promise of Barisan Nasional (the political party in control of the then federal government) to build the 9,999 homes, it would still incur financial losses - with the assumption of a financing cost of $4 \%$ over the RM1.38 billion it spent on buying the land, it works up to RM55 million interest payment per year. 


\subsubsection{Murabahah Notes}

In June 2015, in The Edge Financial Daily Ho Kay Tat the group chief executive officer and the publisher of news group The Edge had mentioned the following (Kay Tat, 2015a): "It is bad enough that 1 Malaysia Development Bhd (1MDB) has not been very transparent in keeping the public informed of its operations, but what is worse is that when it does say something, it always does not address the questions at hand." In the next few lines of the report, Ho Kay Tat talked about the then 1 MDB president and group executive director Arul Kanda Kandasamy's media statement the day before over an article published by The Edge Malaysia Weekly on Saturday. He claimed that Arul had mentioned that the 1MDB's board of directors "categorically denies that it had ever approved any action or series of actions to transfer funds from the company to any third party other than the intended beneficiaries". But as Ho Kay Tat put it: "Nowhere in the article, which was based on documents and email trails, did The Edge say that the board of 1MDB had approved of any transfers of cash to any unintended third party." Instead, the article had merely asked whether the 1MDB's board was aware of the following:

... that two 1MDB executives Casey Tang and Nik Faisal Ariff Kamil, had worked with Low Taek Jho or Jho Low and top executives of PetroSaudi International Ltd to get 1MDB to subscribe to US\$500 million of Murabahah notes, and that US\$260 million was subsequently channelled to Jho Low's Javace Sdn Bhd to buy UBG Bhd. This was based on bank transfers documents sighted by The Edge.

And so Ho Kay Tat had next listed down the questions which he had raised earlier - but this time, he had said this too: "Arul, can you get your board of directors to answer these questions?" And the questions are as follows:

i) Was the board aware that Casey Tang and Nik Faisal had helped raised cash from 1MDB to enable Jho Low to take over UBG (as proven by the emails)? Why were they helping Jho Low and PetroSaudi since 1MDB was not involved in the takeover of UBG? Does the board approve of what they did? Will the board haul up Casey Tang and Nik Faisal to explain?

ii) Was the board aware that US\$260 million of the US\$500 million in Murabahah notes that it subscribed to in 2010 was channelled to Javace for its general offer of UBG?

iii) Did the use of the US\$260 million for the UBG takeover comply with the approval given by Bank Negara Malaysia (BNM) to remit the US\$500 million out of the country?

iv) Doesn't the board of directors of 1MDB have a fiduciary duty to ensure that the conditions set by BNM are complied with, specifically that the money remitted out is used for the intended purpose as approved? Doesn't the board have a duty to ensure that 1MDB staff work in the interest of the company and not for outsiders?

\subsubsection{MDB's RM15.4b is Cash or 'Units'}

In June 2015, Cindy Yeap has mentioned the following in the very first paragraph of her report in The Edge Financial Daily (Yeap, 2015a): "Retaliating against allegations of RM27 billion "missing" cash, 1Malaysia Development Bhd (1MDB) yesterday provided a summary and two infographics detailing how its RM42 billion of debt as at end-March 2014 is accounted for..." Next, she claimed that the disclosure had left several pertinent questions unanswered. Hence, she had this to say: "Will 1MDB president and group executive director Arul Kanda Kandasamy be similarly detailed 
in replying to all these questions?" And so in regard to the RM15.4 billion or over one-third (37\%) of the money invested in three parties - Brazen Sky (RM6.1 billion), GIL Funds (RM5.1 billion) and Aabar Investments deposits (RM4.2 billion) - she said:

Of particular interest is the RM11.2 billion in Brazen Sky and GIL Funds that 1MDB listed under investments, which accounts for nearly $27 \%$ of the RM41.8 billion 1MDB borrowed up until end-March 2014.

Is the RM11.2 billion in Brazen Sky and GIL Funds in the form of cash, units or widgets?

If the RM11.2 billion is cash, where is the money?

Which bank and which country is the money parked in and why?

Is the money in Malaysia? And if it's not, why?

If the RM11.2 billion is in the form of "units", are they still worth RM11.2 billion today?

She pointed out that the answers to these questions are important

... because it was only recently known that the US\$1.103 billion (RM4.059 billion) 1MDB redeemed from Brazen Sky's fund in Cayman Islands is not "kept in US dollars", but as "units" in BSI Bank Ltd in Singapore. It did not help that the revelation only came after news got out that some jittery bondholders of a US\$975 million loan Deutsche Bank Singapore arranged for 1 MDB had asked for their money back earlier than end-August this year, because they doubt the value of the Brazen Sky "units" used as collateral for the bond.

And when it concerns the RM4.2 billion that 1MDB listed as Aabar Investment deposits, she claimed that it had been kept by Aabar's parent International Petroleum Investment Company (IPIC) since 2013 as security deposit for agreeing to guarantee some US\$3.5 billion in loans - but this refundable deposit that was also linked to the options $1 M D B$ granted to bolster the listing of its energy assets had since been terminated. Next, she inquired:

Has the RM4.25 billion now been invested in Aabar Investments instead? If so, why and under what terms? If not, why has the money not been returned to 1MDB by Aabar Investments?

Will 1MDB be able to get at least RM4.25 billion cash from Aabar Investments if it is to recall the money now?

It should be worth mentioning that in ending her report, Cindy had mentioned the following:

A detailed and transparent answer to these questions would help win back some public confidence in $1 \mathrm{MDB}$, whose opaque dealings and sizeable debt have fanned growing public mistrust of government-linked institutions. Conversely, not answering these questions would mean 1MDB continues to be selective in answering only what it wants, but not what the public wants to know.

\subsection{Litanies of Comprehensive Questions}

There are more than a few sources providing different lists of questions covering more than a few areas of concern. The notable ones include those from P. Gunasegaram, Lim Kit Siang, Tun Dr.Mahathir and Tony Pua. Their lists of questions together with a number of other lists of questions are delineated next to provide the picture that the litanies of questions that different parties have raised over the years are quite comprehensive in nature and that it is quite mind boggling to find that there is such a case around in today's Malaysia involving the federal government. Indeed, it is as if "anything goes" appear to be the 1MDB's motto over the years. 


\subsubsection{Media}

In all estimations certain parties from The Edge Malaysia and for that matter The Edge of Malaysia as a whole in comparison to P. Gunasegaram and Kinibiz and for that matter Malaysiakini as a whole had had to bear more brunts for all that they did in pursuing the 1MDB story prior to May 9, 2018 general election. On what the former had had to go through is to some extent laid out in the next section "Answers" of this case study. But, all that must be worth it as may be inferred in a write up published in The Malaysian Insider in February 2015 that came with the byline "Commentary by The Malaysian Insider" (Commentary by The Malaysian Insider, 2015a):

Much has been said, speculated and analysed about 1Malaysia Development Bhd (1MDB). Why the special interest, why some media outlets like The Malaysian Insider and The Edge Media Group at large are pursuing the matter relentlessly. Our critics have even said there is a political objective to it. Well, it is not just The Edge Media Group which has demanded more disclosures and answers from 1MDB, but also Tun Dr Mahathir Mohamad and Tun Daim Zainuddin. Both men are no fans of The Edge Media and we have been critical of them when they were in government. But with regards to $1 \mathrm{MDB}$, we are on the same page. We want to prevent the RM48 billion liability of $1 M D B$ from bringing the country's financial system down. As Daim said on Wednesday, asking questions and criticising the opaqueness of $1 \mathrm{MDB}$ is not about politics, it is about the interest of the country... We say kudos to Dr Mahathir and Daim for being willing to speak out about 1MDB as their voice will carry the necessary weight for action to be taken to prevent 1MDB from becoming one major disaster for Malaysia. (Emphasis added.)

And the need to avoid 1MDB from bringing the country down had led The Edge Malaysia Weekly with the byline The Edge Malaysia in June 2015 to mention that it was not right to argue that all was well in the 1MDB since its financial statements from FY2010 to FY2014 had been signed off by the international accounting firms like KPMG and Deloitte (The Edge Malaysia, 2015b). It stated:

The argument that because 1MDB's accounts have been signed off by auditors meant that no fraud has occurred and that money is not missing is flawed. It shows that these people do not know what they are talking about. They have badly misinterpreted, deliberate or otherwise, the role of external auditors and they do not understand the meaning of an auditor's report when the auditors sign off the financial statement of a company.

Also, early on in the write up, the following notable was mentioned:

This argument has been used to justify the not-so-elegant silence of the management and board of directors of $1 \mathrm{MDB}$, who have refused to respond to questions posed to them about various transactions and the movements of billions of ringgit. They hide behind that argument despite the fact that $1 \mathrm{MDB}$ has run into serious cash-flow problems and can no longer service its debts, and so many questions have been raised about the whereabouts and nature of the so-called Available-For-Sale Investments valued at RM13.38 billion in its accounts for financial year ended March 31, 2014... 
And later the write up had this pointed out: "There are NO auditors in this world who will agree that their signing off an account can in any way or form be interpreted to mean that they confirm or guarantee that the accounts are completely true, accurate and do not contain any misstatements, by fraud or error." Next, it talked about the external auditor's role on paper, the expectation gap phenomenon and the reality of company audit practice. And as far as the 1MDB is concerned, it pointed out: "The questions asked of $1 \mathrm{MDB}$ mainly relate to the effectiveness of internal controls and corporate governance." Next, the newspaper listed down the questions on $1 \mathrm{MDB}^{\prime}$ s internal controls and corporate governance. And right after the listing of these questions, the following is mentioned:

All these major issues that have been raised are about internal controls, decision-making and corporate governance at $1 \mathrm{MDB}$. Deloitte, in their audit report, had clearly stated they are NOT expressing any opinion on the effectiveness of $1 \mathrm{MDB}^{\prime}$ s internal controls. So, please stop passing the buck to Deloitte or using the fact that it signed off the accounts to say that nothing wrong has happened and that everything at 1MDB is fine.

As for the litany of questions, it is as follows:

- Who approved the agreements and the various payments made since 2009?

- Why were funds diverted from what they were approved for? Why was money sent to an account controlled by Jho Low

- Why did $1 M D B$ overpay for the power assets, the Penang land and the commissions to the bankers like Goldman Sachs?

- Who verified and agreed to pay the US\$700 million to PetroSaudi, purportedly as settlement of a loan?

- Why was Jho Low giving instructions to the management on matters of 1MDB?

- Who agreed to the Aabar options and then agreed to a termination settlement that cost 1MDB US\$1.0 billion?

In addition to the June 2015's list of questions, it should be worth noting that a few months earlier in March 2015 Azam Aris the editor in chief of The Edge Malaysia had detailed out in The Edge Malaysia Weekly a barrage of questions that came in the form of one single paragraph (Azam, 2015). Early on Azam Aris mentioned the economic downturns that the country has experienced since the 1980s and what these had entailed as far as the nation's economic and political players were concerned. In particular, he talked about the lessons learnt following the 1997-1998 Asian Financial Crisis had proven to be of benefits to the concerned parties during the global financial crisis of 2008-09 but such was not the case as far as the 1MDB is concerned - as shown by his barrage of questions:

In 1MDB's case, why must the government, via the Ministry of Finance, buy power assets from the private sector? And at inflated prices, using borrowed money, without the expertise needed to manage the business? Why was there a need to borrow heavily in short time frame of five years to accumulate assets and not grow the business organically? It does not take a financial expert to know that overleveraging renders a business unsustainable, which the government now admits is the case with 1 MDB. Why go to all this trouble when after the initial public offering of its energy assets, $1 \mathrm{MDB}$ is likely to end up with only $20 \%$ of the equity? And now it seems that the MoF is also considering selling these assets as an alternative to the 
IPO. If that is the case, then why buy them in the first place? Why invest in PetroSaudi in the first place? Why wasn't there thorough due diligence? Why take the Cayman Islands route? And there's a host of other whys raised by many people and the media, including this weekly. And inevitably as common sense would have dictated, Azam concluded his piece by saying that "... the biggest disappointment in this whole $1 \mathrm{MDB}$ affair is the failure of the board to play its role as an effective check and balance mechanism, the MoF as the owner, and the Cabinet as the guardian of the government's investments. Too many questions, including the obvious ones, were not asked by them. In short, they let the nation down."

The questions from The Edge Malaysia and Azam Aris are of course preceded by several other lists of questions. Among the notable ones are those from Kinibiz's P. Gunasegaram. And Gunasegaram's very first list of questions came out in early April 2013 in the eighth and final part of a series of writing on $1 \mathrm{MDB}$. Related to this, it is notable that in the introduction to the series in late March 2013, Kinibiz had the following most damaging thing to say (Kinibiz, 2013):

It has been described as biggest ponzi scheme the nation has ever seen. When one examines the trail of deals made by 1Malaysia Development Bhd, including RM20 billion in bonds and acquisition of dubious assets and even more dubious partners, there is plenty - and we mean plenty - to worry about. The ultimate conclusion is that this self-styled strategic investment fund does not at all appear to be so both in terms of its operations and the areas it has chosen to operate in, leaving unanswered questions over governance, transparency and accountability.

And that very list of questions of was also preceded with the following remark (Gunasegaram, 2013a):

In a series of articles, KiniBiz has looked at 1Malaysia Development Bhd's various deals and raised some real issues with respect to them, starting from their first RM5 billion bond issue to their joint-venture with PetroSaudi International Ltd, the subsequent withdrawal from that, further bond issues, acquisitions and proposals. 1MDB's cloak and dagger style of operation with many unanswered questions and dubious dealing is very unbecoming of a sovereign fund that is supposed to make strategic investments that will be of value to the country.

As for what came right after the listing of the questions, it is as follows:

If government companies and sovereign funds are to set an example for standards of corporate governance, transparency and accountability it is very clear that 1MDB has failed on all accounts... If nothing - no answers, no action - is forthcoming it will be sad indeed for governance, transparency and accountability in Malaysia and demonstrate yet again a blatant disregard for honest, decent, competent and ethical behaviour of those entrusted with billions of ringgit in public money

As for the questions covering various issues which P. Gunasegaram had argued to "have plagued the fund":

1. Why was the first bond issue of RM5 billion done with so much secrecy? Was it mispriced? Why was it necessary to have such a long tenure of 30 years? Who got the bonds? Why was it not offered to our institutions like the Employees Provident Fund? 
2. The joint-venture with PetroSaudi International Ltd. How come PetroSaudi put in an oil reserve in the Caspian sea as part of the deal? Wasn't 1MDB's strategic direction to get in investments into Malaysia? What was the JV supposed to do? Who is PetroSaudi?

3. On the exit from the JV with PetroSaudi. Why accept debt papers from PetroSaudi as payment? Didn't PetroSaudi have enough cash? Did it not effectively mean that 1 MDB had basically raised funds only to fund PetroSaudi?

4. Why increase the debt to PetroSaudi even more to the extent of RM5.71 billion - more than the RM4.4 billion raised via the bond? Isn't it true that all of the money from the first bond and more went to PetroSaudi, meaning a government-guaranteed bond and more was simply on-lent to the company? Why? What kind of strategic merit was there is this deal?

5. The second bond of US\$1.75 billion was made at very favourable terms to buyers and described as a mysterious placement? Why the secrecy? Why was it considerably mispriced to the advantage of buyers? Who got the bonds? Again, why were government institutions such as EPF excluded? Why did a unit of the Abu Dhabi government guarantee this?

6. Is there a plan to issue another US\$3 billion bond as reported by Bloomberg? What are the terms? Will local institutions partake? What is $1 \mathrm{MDB}$ doing to ensure that the bonds are priced at favourable terms to $1 \mathrm{MDB}$ ? What is $1 \mathrm{MDB}$ going to do with the funds raised?

7. Why was there such a hurry to buy power assets? Is it to get some cash flow in? Why the overpayment? T Ananda Krishnan's unit made a gain of an estimated RM2 billion from the sale of his assets while Genting Bhd made a gain of an incredible RM1.9 billion from the sale of its power assets to 1MDB for RM2.3 billion. Besides Genting's concession ends in february 2016. What justification is there to pay that much under the circumstances?

8. Jimah Energy Ventures Holdings - is there a plan to acquire this power asset for RM1.7 billion as reported? The reported price looks way too high for a company which is still bleeding red ink at the moment? What is the justification?

9. Why bring in foreign partners for the two main real estate developments the RM27 billion Tun Razak Exchange (TRX) and the RM20 billion Sungai Besi airport land? This was on land obtained cheaply from the government. Why pass on benefits to a third party? Couldn't 1MDB plan the development itself with reputable consultants? Isn't there a worry that there will be oversupply, especially from the TRX Development?

10. Who is directly responsible for this series of highly questionable decisions by $1 M D B$ ? Are the 1MDB board and its advisory panel all fully aware of what is going on? If they are, why have they agreed to these? What measures are they putting in place to ensure that 1MDB's interests are protected and bring to account anyone responsible for decisions detrimental to $1 \mathrm{MDB}$ ?

Later in the following year 2014 in early November P. Gunasegaram had again come out with another list of ten questions for the 1MDB to answer following what he believes to be the company's failure to "clear the air" in its press statement (Gunasegaram, 2014a). As he put it: "If $1 M D B$ truly wants to clear the air, here are 10 basic questions begging to be answered for a long time." And it should be worth pointing out that Gunasegaram had concluded his written piece with the following words: 
If $1 \mathrm{MDB}$, our strategic investment fund, can give full and satisfactory answers to these pressing questions let them do so. Otherwise they must be simply regarded as a multi-billion ringgit renegade government company which has gone totally out of control, operating according to its whims and fancies and that is a danger to the country and its people.

As for the list of questions (with the emphasis already on):

1. Why were your bonds badly mispriced? This is the way that most of the money is being siphoned off. By pricing what are effectively government-guaranteed bonds low, those who get the bonds at that price merely have to flip it on the market for a massive gain. KiniBiz calculations show that for the first few tranches amounting to RM20 billion, the mispricing is worth RM4 billion! How much more was mispriced for the subsequent loans which amounted to some RM17 billion? Perhaps another RM4 billion? Can we assume you allowed RM8 billion to be siphoned off upfront from loan mispricing?

2. Why did you pay such high fees for your loans? When your bonds were offered on such attractive rates, why was there a need to pay $10 \%$ or more to place these out when $2 \%$ or less is the norm? Who did these fees of more than RM400 million go to? Is this yet another means of enriching some people by siphoning off what belongs to 1MDB?

3. Why did you make such crazy investments with your borrowings? $1 M D B$ is a strategic fund which is supposed to attract like investments into the country. Yet you are financing other people for investments they are making elsewhere and in quite dubious ways. Are even the funds you raise in inefficient and corrupt ways at risk and earning too low a return?

4. Why do you have so much cash and still borrow money? Your accounts as at March 31, 2013 show you have cash or near cash items of over RM23 billion. Why are you going on such a borrowing spree when the money sits there already earning very little? Is it because you have lucrative ways to misprice loans for the benefit of a few and want to exploit this to the full?

5. Why is most of your profit to date from property revaluations? If not for property revaluation gains of RM2.7 billion in the last available accounts you would have made losses. Basically, the gains came from revaluing cheap government land allotted to you to market rates. Does this not imply that despite RM37 billion in borrowings, you are still not getting enough on your investments and have to resort to this to show profits?

6. Why are you developing property when there is a glut? How strategic is property development when you basically get cheap land from the government and develop it, especially during a time when a glut is developing?

7. Why are foreigners involved in your property projects? Alright, you maintain land is strategic but why do you need foreigners as partners to develop this land? Can't you just hire the best people money can buy and do it yourself? Then you can develop a masterplan, require developers to build according to plan and open out tenders to everyone. Are you using joint ventures so you can siphon out further value from 1MDB through these foreign partners? Is that not selling out our own country?

8. Why did you go into power? Power is about the only assets you bought which will have a steady recurrent income. But you paid way too much. Is that yet another way of 
siphoning money out of $1 \mathrm{MDB}$ ? And is the purchase of power assets an attempt to quickly get cash generating assets which you sorely lack?

9. Why do you want to list your power assets? You obviously don't need money going by your last balance sheet which showed cash and and near cash items at a whopping RM23 billion plus. That makes your desire to list the power assets rather strange. Is the awarding of a slew of power contracts to you a ploy to increase the value of your power holdings so that on listing you will have realised gains which can offset losses elsewhere?

10. Why are your accounts delayed yet again? This is the third time that we know off that your accounts have been consecutively delayed. Are you negotiating with your latest auditors - your auditors have been changed twice already - to give the best possible picture for your accounts? Come on, tell us, what are you trying to hide?

Further, in March 2015, and it was just fewer than six months after his previous list of ten questions for the 1MDB to answer, P. Gunasegaram had come out with still another list of questions (Gunasegaram, 2015a). This list of questions was produced in response to the remark made by the federal cabinet then that the 1MDB had done no wrong. As P. Gunasegaram clarified early on in his writing:

There are very primary things which are wrong with self-styled strategic development company 1 Malaysia Development Bhd or $1 \mathrm{MDB}$. Thus it is rather premature for the Cabinet to conclude that there has been no wrongdoing, which is what a statement from the Prime Minister's Office says... It appears that the Cabinet maintaining that there is no wrongdoing at $1 \mathrm{MDB}$ comes following briefings by $1 \mathrm{MDB}$ officials and its auditor Deloitte. That in itself is not sufficient to clear 1 MDB of wrongdoing because that can take place even with accounts that have not been qualified. Indeed, much of what is wrong at 1MDB is not just at the accounting level of things.

Next, as he put it: "Here are 10 groups of questions... So far - over two years - we at KiniBiz have not managed to get answers from them..." And as part of the concluding end of his devastating piece, he had this to say:

Good account keeping - if indeed that is good at $1 \mathrm{MDB}$ - does not necessarily indicate that there are no wrongdoings. If you price your bonds wrongly for instance, nothing will show up as wrong in your accounts. But you would have squandered billions of ringgit of public money through the higher interest rates that $1 \mathrm{MDB}$ has to pay, sometimes for as long as 30 years. Smart people don't misprice by mistake, they usually do so for gain. There is considerable scope for wrongdoing here. Likewise for high fees paid, overpaying for assets, questionable use of assets and so on... There is plenty of evidence of wrongdoing at 1MDB - what we have outlined here and others beyond that... The smell is already in the air but the problem is that no one in authority wants to admit that it stinks!"

And now the questions:

1. Why borrow to the extent of RM46 billion (as at end March 2014) when the only solid assets are in power generation which cost around RM11 billion? Where is 1MDB going to get over RM3 billion in interest payments yearly on these loans from the assets it has? And we are not even talking repayment. 
2. After taking RM11 billion out for power assets out of borrowings of RM46 billion, there is RM35 billion left. How exactly have these assets been invested, what is the return and what is the strategic impact upon the country of these acquisitions?

3. Why are some RM13 billion of assets (as at March 31, 2014) classified as assets-for-sale? Why are they for sale? Will money be lost when these assets are sold?

4. With so much of liquidity, why was $1 M D B$ very publicly scrambling to raise money to repay RM2 billion to Malaysian banks? Did it have to borrow the money from tycoon T Ananda Krishnan for this? Is all the money intact and accounted for?

5. Is it viable to borrow at effective rates of around $7 \%$ and then invest this money to try and get a better return and to attract strategic investments into Malaysia? What are the strategic investments and benefits to Malaysia so far?

6. Why were its bonds so badly underpriced, giving those who obtained first bite of these bonds the chance to repeatedly make billions of ringgit upfront when they sold their bonds at much higher prices on the open market?

7. For arranging what are effectively government-guaranteed bonds and borrowings, it paid hundreds of millions of ringgit in fees, primarily to Goldman Sachs, far above the norm seen for the industry. Why?

8. Why did it overpay so much for the power assets and what was the strategic impact if any at all of buying power assets owned and operated by Malaysians, much of it in Malaysia? Remember these were largely independent power producers which have now become government owned. Please explain how that can be strategic.

9. Why were the accounts delayed numerous times and the auditors changed a number of times?

10. What is it's strategy moving forward?

And finally in the following month of April, Gunasegaram had come out with the so called "checklist of 10 things" (Gunasegaram, 2015b). Early on, he made the claim that 1MDB could be facing a situation where it "... does not understand what it needs to do to convince the public all is well with it." Next, as he put it: "To help it along, here are 10 things that we feel our national self-styled strategic development company can do to soothe frazzled nerves and convince us Malaysians our money is safe." The "checklist of 10 things" is as follows:

- Explain why there was a need to borrow RM42 billion at least when the energy assets only cost some RM13 billion and TRX and Bandar Malaysia are merely in the development stage.

- Reveal exactly where and at what rates of return are the rest of the money of RM29 billion at least being kept, including the Singapore/Cayman funds. Tell us what is the amount recoverable from this and how you propose to recover them. Also explain why 1MDB was scrambling for cash to repay a loan of RM2 billion recently to local banks. Tell us too what was tycoon T Ananda Krishnan's role in all of these.

- Explain why such high fees of several hundred million US dollars was paid to Goldman Sachs for bonds floated and what was the nature of their role in such deals. While normal rates for arranging such financing is closer to 1 percent, why the need to pay 10 percent for these? 
- Explain how keeping RM29 billion in deposits and for-sale assets overseas is strategic and helps in bringing foreign direct investments or FDI into Malaysia.

- Was there hanky panky in the fundraising process whereby bonds were mispriced, allowing those who got the bonds to cash out in the secondary market to gain billions of ringgit? Was this the reason why the debts were ramped up repeatedly? If not explain why the bonds were mispriced and who were the beneficiaries, in other words who got first bite at the bonds.

- With RM42 billion of borrowings and an average interest rate of 6 percent, annual interest payments before repayments amounts to over RM2.5 billion. Considering that $1 M D B$ has been making cash losses since inception, explain how 1MDB proposes to obtain the interest payments and repayments in future especially since energy assets are now worth below cost.

- Explain the business model for $1 \mathrm{MDB}$. How does it propose to get decent returns when its cost of borrowing may be 6 percent or higher, especially for huge borrowings of at least RM42 billion and as high as RM46 billion.

- Explain how the property developments are "strategic" and why we need foreign partners to develop these when Malaysia has considerable expertise in property development. What about causing a glut of office space in Kuala Lumpur and squeezing out private developers? Explain how that is strategic.

- Explain to us what is the oversight of the board and senior management over all these issues, especially in the light of Sarawak Report disclosures - which have not been firmly denied - that outside parties played crucial roles in decision-making.

- Tell what exactly was Jho Low's (right) role in $1 \mathrm{MDB}$, when it started, how big was it and at whose behest did he have such a powerful pull over decisions made at 1MDB.

\subsubsection{Politicians}

There are three notable politicians who for a period spanning several years prior to the GE14 were adamant in getting to the truth about 1MDB. These are Lim Kit Siang, Tun Dr. Mahathir Mohamad and Tony Pua. All three have their blogs replete with postings on 1MDB and related matters. In the case of Tun Dr. Mahathir in particular he started questioning 1MDB and those closely related to it in September 2014. A sample of the headings of news reports starting from the second week in September 2014 to early March 2016 which is concerned with his criticisms of concerned parties is as follows:

- Dr M raises questions about 1 MDB in his blog (September 11, 2014)

- Dr M stopped short of asking Najib to resign, says veteran newsman (September 12, 2014)

- I am nasty when necessary, says Dr M (September 19, 2014)

- Umno needs to transform to criticise its leaders, says Dr M (September 29, 2014)

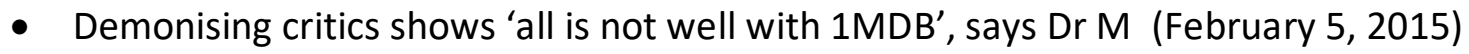

- Dr Mahathir says his financial mistakes not as bad as Najib's (April 7, 2015)

- Why can't Najib answer simple questions, asks Dr M (April 9, 2015)

- Umno today is about money, Dr M fires back at critics (April 13, 2015) 
INTERNATIONAL JOURNAL OF ACADEMIC RESEARCH IN BUSINESS AND SOCIAL SCIENCES

Vol. 8, No. 12, Dec, 2018, E-ISSN: 2222-6990 @ 2018 HRMARS

- I expected Najib to do better than Pak Lah, says Dr M (April 20, 2015)

- Dr M brings up Rosmah in latest attack on Najib (April 20, 2015)

- Dr M fires new salvo at Najib (April 21, 2015)

- Najib must step down over 1MDB's 'disappeared' funds, says Dr M (April 23, 2015)

- Dr M asks PM what happened to RM27b 1MDB funds (April 24, 2015)

- Just tell us where is $1 \mathrm{MDB}^{\prime}$ 's money, says Dr M (May 18, 2015)

- Parliament rejects qns on TRX and calls by Tun M for Najib to resign (May 18, 2015)

- Najib made a bigger mess than Pak Lah, says Dr M (May 29, 2015)

- Dr M says Najib will lose GE14, risk legal action over 1MDB cover-up (June 4, 2015)

- Yes, I am behind $1 M D B$ 'crisis', says Dr M (June 11, 2015)

- $1 M D B$ problems will end if Najib resigns, says Dr M (June 11, 2015)

- Dr M using 1 MDB to topple me, says Najib (June 12, 2015)

- Najib must be first to go in cabinet reshuffle, says Dr M (June 12, 2015)

- Statements on dubious 1 MDB deals useless without proof, says Dr M (June 15, 2015)

- Show proof, not hide behind 'government matters', Dr M tells 1 MDB (June 18, 2015)

- Dr M: Najib afraid of criminal charge (June 22, 2015)

- There's no conspiracy, I have openly asked Najib to go, says Dr Mahathir (July 20, 2015)

- It's now a crime to talk about $1 M D B$, says Dr Mahathir (July 31, 2015)

- Grim future for Malaysia as Najib has 'stolen the government', says Dr Mahathir (August 17, 2015)

- No-confidence vote against Najib legal and necessary, says Dr Mahathir (August 20, 2015)

- Umno MPs won't vote against Najib if BN toppled, says Dr Mahathir (August 20, 2015)

- A good leader's focused on nation, not self, says Dr Mahathir in latest attack on Najib (October 8, 2015)

- Najib does not respect separation of powers, says Dr Mahathir (October 20, 2015)

- I will continue to ask Najib to resign, it is my right, says Dr Mahathir (November 13, 2015)

- $\quad$ 1MDB still misleading the public, says Dr Mahathir (December 3, 2015)

- Najib must quit, A-G not credible, says Dr Mahathir (February 5, 2016)

- We have only one thing in common - remove Najib as PM, says Dr Mahathir (March 4, 2016)

And each of the three politicians had done quite a sterling job in raising penetrating questions on $1 \mathrm{MDB}$ and related matters. In the case of Lim Kit Siang his list of questions appeared in November 2014 in his blog post that come with the heading (Kit Siang, 2014): "Najib should not set bad example to other Ministers by using threat of legal suit against Tony Pua to evade accountability and should make Ministerial statement to answer teeming questions on 11 aspects of the multibillion ringgit $1 \mathrm{MDB}$ scandal in Parliament on Monday". And his questions were:

1. Why did the Government issue a "letter of support" for 1MDB's US\$3.0 billion (RM9.6bn) bonds issued in Mar 2013 which not only explicitly binds the Government to repay the debt in the event $1 \mathrm{MDB}$ fails to do so, but surrendered legal jurisdiction to the Courts of London? Despite the denial that the letter represents an explicit "guarantee", why isn't this amount 
recorded as a Federal Government contingent liability since Malaysia is legally bound to repay the debt in the event of 1 MDB default?

2. Why did 1 MDB pay an average of more than $10 \%$ in "certain commissions, fees and expenses" to raise its loans - US\$3.0 billion (Mar 2013) and US\$1.75 bilion (May 2012), when other developing nations such as Uruguay pay as little as $0.1 \%$ to raise US\$2.0 billion? Even Penerbangan Malaysia Bhd which raised US\$1 billion recently paid only $0.5 \%$ in such fees.

3. Why did 1MDB divert US\$1.1 billion of its US\$3.0 billion raised by its subsidiary, 1MDB Global Investment Limited to repay the former's own debt and cover its operating expenses? The "Use of Proceeds" of the US\$3.0 billion bond as stated in the investors' prospectus was to invest in a 50:50 joint venture with Aabar Investment. Additionally US\$1.56 billion is parked at an unknown investment fund overseas while the proposed joint venture is stillborn after 18 months.

4. Why did $1 M D B$ agree to accept a corporate loan guarantee by International Petroleum Investment Corporation (IPIC) of Abu Dhabi on behalf of 1MDB's US\$3.5 billion of bonds with such onerous terms - $40 \%$ security deposit and a 10 -year option to acquire $49 \%$ of $21 \mathrm{MDB}$ subsidiaries. The 10-year option is worth at least US\$250 million. As a result of the loan's $5.99 \%$ interest, the IPIC guarantee and the $10 \%$ of "certain commissions, fees and expenses", the effective cost of fund to 1MDB for the US\$3.5 billion loan is a staggering $13.98 \%$.

5. Why did 1 MDB invest US\$1 billion in a joint-venture with PetroSaudi in 2009, a company with no track record and dubious origins and subsequently converted the investment into a US\$1.2 billion loan, which was subsequently increased to US\$1.7 billion? Although 1MDB claimed the loan as been redeemed in full and the proceeds parked in Cayman Islands, it must answer for the risks taken as well as the complete lack of transparency and good governance as these sums were entirely funded by debt.

6. Why did $1 M D B$ invest the US\$2.32 billion proceeds from the redemption of Petrosaudi loans in 2013 in an opaque investment fund with Bridge Capital Partners in Cayman Islands, an unknown fund manager with questionable origins and no comparable track record?

7. Why did the Ministry of Finance hastily acquire a 1MDB subsidiary, SRC International Sdn Bhd in March 2012 which has then just received a RM4 billion loan from Kumpulan Wang Amanah Pesara (KWAP) guaranteed by the Federal Government?

8. Why did $1 M D B$ overpay for its power assets - Genting Sanyen (RM2.38bn) and Tanjong Energy (RM8.5bn) which required an immediate impairment of RM1.2 billion out of its recorded goodwill of RM2.6 billion? As a result of the high price of acquisition, The Edge Weekly has estimated an annual return on investment of only approximately $5 \%$, lower than the cost of funds to acquire these companies.

9. Why did the Ministry of Energy, Green Technology and Water reverse it policy of open tenders for new power plants to directly and hastily award a 50MW solar-power plant and a 2,000MW gas-turbine power plant to $1 \mathrm{MDB}$ before even the tariffs are agreed upon?

10. Why did the Federal Government sell super-prime land to 1MDB at heavily discounted prices - Bandar Malaysia (RM1.6 billion) and Tun Razak Exchange (RM194 million), allowing 1MDB to revalue their properties by a whopping RM5.22 billion in less than 5 years? 
11. Why did international auditing firms - Ernst \& Young and KPMG quit their lucrative work with 1MDB in 2009 and 2012 respectively? Why hasn't 1MDB subsidiaries submitted their financial statements to the Companies Commission despite some being overdue by more than 2 years?

After having listed the questions, Lim Kit Siang had ended his blog post with the following demand for the concerned party:

Although the current budget parliamentary meeting is to end on Thursday, 27th November 2014, it will be the height of irresponsibility for Najib as Prime Minister, Finance Minister and Chairman, 1MDB Board of Advisers to evade and avoid accountability for the numerous questions that have been raised over the 1 MDB scandal... Najib should in fact arrange for a full debate in Parliament to be held on his Ministerial Statement on 1MDB.

In early June the following year Lim Kit Siang had a blog post with another interesting title (Lim Kit Siang, 2015a): "10 Questions on 1MDB for dummies for Cabinet Ministers at their meeting today". In the text of the blog piece just before he detailed out the list of questions, he talked about the failure of federal cabinet ministers in their meeting recently to raise questions regarding the then second finance minister Datuk Seri Ahmad Husni Hanadzlah's explanation on the so called 1MDB Roadmap. Among others he mentioned:

...it is obvious that any ordinary person cannot be happy with Husni's explanation of the 1MDB Roadmap. Either the Ministers were living in a different planet and did not know the almost daily queries about the RM42 billion 1MDB scandal or they just buried their heads in the sand like ostriches to shut out the mountain of $1 \mathrm{MDB}$ queries for the past few years. The Ministers will be guilty of the height of irresponsibility and negligence if they had given approval to the 1MDB Roadmap without understanding the issues of propriety, accountability and transparency of the numerous deals in the 1MDB imbroglio, out of fear of stepping on the toes of Datuk Seri Najib Razak Prime Minister-cum-Finance Minister.

Next, he pointed out: "The Ministers must make amends for their gross sins of irresponsibility and negligence on the 1MDB Roadmap at the Cabinet meeting this morning, and the following ten questions on the 1MDB for dummies should be among the questions which Ministers should pose on the 1MDB Roadmap at today's Cabinet." And the questions were:

1. 1MDB President and Group Executive Director, Arul Kanda Kandasamy, denied that Abu Dhabi-based International Petroleum Investment Co (IPIC)'s US\$1 billion mentioned by second Finance Minister Husni Hanadzlah in the 1MDB Roadmap was "a loan, debt or bailout". What animal is this US\$1 billion of IPIC which is not "a loan, debt or bailout"? A grant, gift or present?

2. What $1 M D B$ has to give in return for IPIC's US\$1 billion so that $1 M D B$ can settle its US\$975 syndicated loan?

3. Is $1 M D B$ being wound down by next year and its operations transferred to three separate companies as part of the deal with IPIC and its Aabar Investments unit to remove another RM16 billion debt from $1 \mathrm{MDB}$ - as reported by the government mouthpiece Bernama but subsequently denied by Husni? 
4. Why is IPIC's US1 billion (not "loan, debt or bailout") necessary in the first place? Does mean that the consortium of banks led by Deutsche Bank was right when they rescinded their US\$975 million loan to 1MDB ahead of their due date on August 31 because 1MDB provided "incomplete documents" as security, i.e. "false bank statements" on the US\$1.103 billion being held by 1MDB's Brazen Sky unit in BSI Singapore, originally from a tranche of offshore deposits it previously kept in the Cayman Islands.

5. What punitive action had been taken against the $1 M D B$ officials for such irresponsible and criminal mismanagement resulting in the consortium of banks rescinding 1MDB's US\$975 million ahead of its due date?

6. Whether the Prime Minister under the 1MDB Memorandum and Articles of Association (M\&A) is the final approving authority, and whether he must bear responsibility for the early rescinding of 1MDB's US\$975 million loan by the consortium of international bankers.

7. If the Prime Minister is the final approving authority for any $1 M D B$ deal, transaction or investment under the 1 MDB Memorandum \& Articles of Association (M\&A), ask the Prime Minister for a full report to the Cabinet on all his 1MDB dealings in the past six years as the final approving authority for $1 \mathrm{MDB}$ deals, transactions and investments. Who will now be the final authority on the $1 \mathrm{MDB}$ Roadmap - the second Finance Minister Husni or Najib as provided in the $1 M D B M \& A$ ?

8. How 1 MDB could pile up RM42 billion debts in six years when Najib is the final approving authority for all these transactions?

9. The full relationship of Najib and the "mover and shaker" of the RM42 billion 1MDB scandal, Jho Low.

10. Whether Najib should chair or even be present at any Cabinet discussion and decision on the $1 \mathrm{MDB}$ issue because of conflict of interest as the Prime Minister is the final approving authority for $1 \mathrm{MDB}$ deals, transactions and investments.

As for Tun Dr Mahathir Mohamad, in a blog post in June 2015 which was a response to 1MDB's press statement just a couple of days earlier in which the company had claimed that Tun had gotten it all wrong and where it questioned Tun's "motivation" in making "ever-changing claims", this was stated early on (Mahathir, 2015b): "To all my criticisms $1 M D B$, can only say that they are all wrong. But there are no proofs given. The answer is always about secrecy of Government matters." And after having revealed several matters that are concerned with 1MDB, Tun had come out with some devastating remarks interspersed with a number of penetrating questions:

6. So $1 M D B$ issued a 30 -year bond. When it borrows money the suggestion is made that $1 \mathrm{MDB}$ would make money.

7. The yields accrue of $6.15 \%$ or whatever is for the purchasers of the bonds. 1MDB will have to dole out money for 30 years as interest which means it borrows now and our children will bear the burden. And $1 \mathrm{MDB}$ will get only 88 cent to 1 Ringgit. What is so good about that. 
8. Okay. The interest p.a. is RM 2.4 billion and not RM3 billion. Can 1MDB pay that amount? Already it had to get money from Ananda and the IPIC to pay. Borrowing money to pay interest does not reduce the principal. It only increases the debt. Even if it is payment for shares or whatever the loan would still be there. So you cannot explain more. It is confidential - secret.

9. Thirteen power plants bought. But the big ones in Malaysia can be bought for a song. But by paying RM18 billion, 1 MDB overpaid at least by RM3 billion. Why? If they are good assets, why cannot they be listed? Why is it that when Tenaga and Malakoff were rumoured to buy 1MDB power plants, their shares all plunged.

10. $1 \mathrm{MDB}$ is a Government company but when it bought Government land at $1 / 50$ th of the market price, the Government lose a huge sum of money.

11. When $1 M D B$ sells the land, it is merely taking what should be Government earnings from the sale. That process is no different from people who sell APs, contracts and licence. Is this how $1 \mathrm{MDB}$ expects to make money?

12. Is $1 \mathrm{MDB}$ a strategic development company? What has it developed - nothing. Even TRX is all fence and nothing else.

Six months following his June 2015's litany of questions, in December 2015 Tun Mahathir in another blog post had listed down another series of questions (Mahathir, 2015c). Early on he made the claim that the 1 MDB in its "clarifications on issues raised" was "still misleading the readers in my blog and others." Next, he bombarded the company with the following series of questions:

3. You said $1 M D B$ is a strategic investment company. When you sell assets which you acquired at a very low price from the Government and pocket the difference is that what is called strategic investments? Buying business at higher than market price is that what you regard as strategic investment?

4. You are also going to sell $40 \%$ of former Government land at Sungai Besi which you acquired at below market price is that strategic investment? Sounds more like selling APs (Approved Permits) which you get free from the Government.

\section{Are these how $1 \mathrm{MDB}$ makes money through strategic investments?}

6. While Edra is sold to a foreign company you try to sell land to local Government linked company which collect funds from the people. So people, pilgrims and Malaysian citizens have to buy $1 \mathrm{MDB}$ land, so you can pay your debts. You are in fact forcing citizens to pay your debt with their hard-earned money. Is this also strategic investment? 
7. How did you raise RM42 billion? Is it through borrowing? How much of that is borrowed in Malaysian Ringgit? Show documentary evidence and the banks you borrowed from. If you are paying them back in Ringgit, the devalued Ringgit will not be of the same value as the Ringgit you borrowed. Each US Dollar equivalent will be one Ringgit less. The banks will carry this loss. Yes this is strategic investment except when borrowing you did not know the Ringgit would devalue so much.

8. If you borrow in US Dollars, explain how much and from whom. Did you pay 10 per cent commission to Goldman Sachs? In which case you will be paying the 5.9 per cent interest on 100 per cent of the loans but getting only 90 per cent of the total loan. Again show documentary proof. Don't just say it is not true.

9. If you had borrowed US Dollars, the value of each would have been RM3.2 per dollar. Now you would have to pay back at RM4.2 per dollar. How much dollar investments have you made? Apart from the US2 billion dollar you say you have earned, you seem to be unable to pay the interest on your loans. Please give documentary proof of your profits, how it was made and from whom. You are not a private company. You are a Government company and any loss you make will be borne by the public. They have a right to know.

10. You say that the MACC had verified that the RM2.6 billion in Najib's private account did not come from 1MDB. Government departments and personnel are now under pressure. They can be sacked or transferred. A DPP was dismissed.

11. People making reports are being arrested. Their lawyers can be arrested. People living under threats are not reliable when making statements.

12. So we cannot accept the statement by the MACC personnel just like that. We want proof. We want to know how RM2.6 billion in PM's account is not from 1MDB. We must know where all the RM42 billion are. Your explanations are without proofs.

13. Explaining that you have more assets than the loans you have taken is not enough. Every cent of the money you borrowed must be accounted for. Where is the money from the Caymans? In what form is it? You said you saw it. Is it cash or accounts in bank books. Why did the bank say it doesn't have the money? Which banks now have the money? Who is entitled to withdraw the money? What transactions have been made. If you say it is a secret, I have a right to say you want to keep the amount and the transactions secret. After all RM2.6 billion was secretly put into the private account of the PM.

And with the lists of questions from Lim Kit Siang and Tun Dr. Mahathir Mohamad delineated, next is Tony Pua ("Ten questions for 1MDB chief", 2015). In early November 2015 in The Malaysian Insider in the run up to an anticipated (but what later became a failed) live exchange 
with 1 MDB president Arul Kanda Kandasamy, Tony Pua had made public a total of 10 questions which he wanted to raise during the session. The questions were:

1. Why did Bank Negara withdraw its approval for 1 MDB to transfer more than US\$1.8 billion overseas? Was it because most of the funds were transferred to an account which is unrelated to the $1 \mathrm{MDB}$ joint venture project with Petrosaudi International Limited as revealed in the leaked Board meeting minutes which Arul Kanda has acknowledged to be true? How much was transferred to this unrelated account? Did this unrelated account belong to Good Star Limited and who owns or controls Good Star Limited?

2 . Is it true that $1 M D B$ had invested the initial US\$1 billion cash to acquire $40 \%$ of $1 \mathrm{MDB}$ Petrosaudi while Petrosaudi only need to invest its rights to certain oil reserves in the Caspian Sea and in Argentina for its $60 \%$ stake? In addition, were the rights to the Caspian Sea oil reserves terminated by Petrosaudi within 2 months after the signing of the joint venture agreement, which meant that Petrosaudi secured their $60 \%$ stake without investing anything significant?

3. Is it true that 1 MDB had proceeded to sign the joint venture agreement with Petrosaudi in a rush, without securing the necessary Board of Directors approval at that point of time as revealed in the same Board minutes?

4. 1MDB Financial Statements dated 31 March 2013 and 2014 stated that US\$1.4 billion was held as a deposit by International Petroleum Investment Corporation (IPIC) as a condition for IPIC to guarantee 1MDB's US\$3.5 billion bond issue. However, the IPIC Financial Statements dated December 2013 and 2014 audited by Ernst \& Young did not disclose any such condition for the provision of the guarantee. The balance sheet of IPIC also did not reflect any such refundable deposit received or held. Why hasn't 1MDB sought IPIC to clarify where the money has gone?

5. Did 1 MDB pay US\$993 million from the US\$1.22 billion it partially redeemed from the Cayman Islands investment fund AND another US\$975 million borrowed from Deutsche Bank led consortium to terminate options $1 M D B$ granted to Aabar Investments as part of another condition by IPIC to guarantee 1MDB's US\$3.5 billion bond issue? What exactly is the total sum paid and payable to Aabar or IPIC? Why is it that IPIC disclosed in its December 2014 Financial Statements that 1 MDB still owes IPIC a sum of US\$481 million for the said termination?

In addition, if the US\$993 million from the US\$1.22 billion redeemed from Cayman Islands was not paid to Aabar or IPIC, where did the money go?

6. It has been disclosed in 1MDB's financial statements, parliamentary replies and media releases that 1 MDB Global Investment Limited borrowed US\$3 billion in March 2013 for the purposes in investing in a 50:50 joint venture with Aabar Investments Limited where the joint venture will invest in the development of Tun Razak Exchange. The question is, how come more than US\$1.5 billion of the borrowings have been utilised for purposes other than specified as disclosed in the March 2014 Audited Accounts, particularly since the joint venture has yet to be activated to date?

7. Arul Kanda had earlier informed Malaysians and 1MDB Directors, according to the above leaked minutes, that the balance of the Cayman Islands investment amounting to US\$1.108 
billion was fully redeemed and was held in cash in BSI Bank Singapore. However, the 1MDB President has since admitted that the redeemed amount was not cash but they were "fund units" worth US\$940 million. Why are these "fund units" which were redeemed from the Cayman Island fund still in the form of "fund units" and not in cash or, raw assets like property and shares? If they were in "fund units", doesn't it mean that the Caymans fund was never redeemed in the first place?

8. Arul Kanda announced the "debt for asset-swap" deal with IPIC where the latter assumes some RM16 billion of 1MDB's debts in exchange for 1MDB's assets. IPIC has already advanced more than US\$1 billion in the deal. Where is 1 MDB going to produce these RM16 billion worth of assets to transfer to IPIC by 30 June 2016?

The Ministry of Finance (MoF) has also indemnified IPIC in the "debt of asset-swap" arrangement. Does it mean that if 1 MDB fails to produce the necessary RM16 billion worth of assets by 30 June 2016, the MoF would have to compensate IPIC accordingly?

9. Arul had declared that the disposal of its subsidiary, Edra Energy will allow it to remove RM16-RM18 billion of 1MDB's debt. However, the total debts associated to 1MDB's energy arm amounts to approximately RM36 billion, comprising of US\$3.5 billion of bonds, RM5.7 billion of direct loans and more than RM8 billion of inherited loans. Hence reducing up to RM18 billion of debt via the disposal of Edra Energy will still leave 1MDB with more that RM18 billion of outstanding debt associated with its energy acquisitions. Therefore how will the sale of Edra solve 1MDB's cash flow problem since there'll be no assets left to pay the balance of the RM18 billion debt?

10. Did the Federal Government issue a "letter of support" in May 2015 to Bank EXIM to borrow US\$150 million (RM600 million) where the funds was utilised by 1MDB to pay for its land acquisition from Tadmax Resources Bhd for approximately RM300 million? If so, what was the balance of the proceeds from the borrowing used for?

\subsubsection{Laypersons}

Now that the lists of questions from parties placed under the first two categories of the sources of 1MDB have been dealt with, the lists of questions from the sole representative for the last and third category of laypersons is of interest. In February 2015 in the Free Malaysia Today, T. K. Chua had this to say early on (Chua, 2015a): "When following the discussions on 1MBD, I cannot help but feel that there are still many unanswered questions. If my questions sound too simple, basic or naïve, please forgive me. I must understand the simple things first before I proceed to more complex ones." Later, he mentioned:

... there was an accusation that the money deposited earlier in the Cayman Islands by 1MDB has not been returned to Malaysia. Is this true? $1 \mathrm{MDB}$ has not answered this question directly. Then, there was an allegation that 1MDB had borrowed RM2 billion from a tycoon to settle an overdue loan. Fair enough, 1MBD has issued a statement denying this. But then, where and how did 1 MDB obtain the funds to eventually settle the loan?

And finally after saying that he believed that the government owned company 1MDB owed the public full disclosure on relevant issues, he delineated the rest of the questions to be answered: 
1. Is it true $1 \mathrm{MDB}$ paid higher interest rates, fees and commissions (of equivalent risk) in its borrowings, as claimed by many critics? If so, why? Why were we so dumb?

2. Was it true $1 M B D$ issued bonds at a discount when the coupon rates were not exactly lower than the market rate of equivalent risk? If so, why were we so dumb again?

3. $1 \mathrm{MDB}$ has always claimed that the value of its total assets was higher than its total liabilities. Well and good. How much of $1 \mathrm{MDB}^{\prime}$ 's assets were given to the company by the government at a nominal value (if any), like for example, the land at the Sungai Besi airbase and Tun Razak Exchange? How much of the value of 1MDB's assets now are due to revaluation since the acquisition of these assets?

4. If $1 M D B^{\prime}$ s assets were obtained at a nominal value or due to revaluation or both, how did the company accumulate so much debt?

5. Some critics claim that $1 \mathrm{MDB}$ has acquired many assets (energy related) at inflated prices. Is this true? If so, how much higher did 1 MDB pay when compared with assets of an equivalent class in the market?

It is notable that two months after producing the above list of questions, T. K. Chua in April in The Malaysian Insider had raised another set of questions (Chua, 2015b). But first do check out his interesting preamble:

While agreeing that some of the problems in 1MDB have become complex and intricate, that does not mean that some of the fundamental questions raised by the public cannot be answered immediately. Let me quote you one piece of information that has been floating around for a long time now. The Prime Minister in his TV3 interview has also alluded to it. It is regarding $1 \mathrm{MDB}^{\prime}$ s assets and liabilities. According to the information provided, 1MDB has total assets amounting to RM50 billion, more than its total liabilities. So the company is "viable" and "solvent".

Next, he mentioned: "I have few questions on this which I believe any junior executive in 1MDB should be able to answer without having to wait for the auditor report." And the questions were:

First, how many times have the major assets in $1 \mathrm{MDB}$, particularly those given by the government for the song, been re-valued? Yes, how many times and what was the total amount of revaluation? Simple enough?

Second, how many percent of the assets in 1MDB's book now was acquired using hard cash/loans and how much was due to revaluation?

Third, if the bulk of the asset value has come from revaluation, can 1MBD please explain how did the company accumulate so much liability? Where did the money from loans and bonds go to?

Fourth, we were informed that $1 \mathrm{MDB}$ has acquired many "about to expire" energy assets at inflated prices. Is this true? If so, how much more $1 \mathrm{MBD}$ has paid for those assets when compared with what other investors would have paid. I know this is a little difficult to answer. But how about I ask 1 MDB this way: what roi is 1 MDB expecting from its investments in energy assets? Please don't talk about potential IPO of these investments because these are birds in the bushes. Just give us the roi of these investments.

Fifth, we were also told that 1MDB has issued lots of bonds (IOUs) - some at discount and some with exorbitant fees and interest rates. This is perplexing. We issue bonds at discount 
only when the coupon rates are lower than the market rates of equivalent risk. So why did $1 \mathrm{MDB}$ issue the bonds at discount when the coupon was in fact higher (as alleged) than the market rates of equivalent risk?

Sixth, after taking into consideration bonds issued at discount, fees and commission to investment bankers and the coupon rates, what exactly is the effective rate of 1MDB's bonds/loans?

Now that all the possible questions on $1 M D B$ have been presented, the next logical thing to do is to provide some delineation of the answers provided. And it appears that there was more than one type of "answers" given by those concerned. All this is pointed out next.

\section{The Answers...}

Surely one would expect answers to come out following the raising of so many questions which include those presented in the previous section? But there existed more than one type of answers! The first was of course where words were used. The second came in the form of forceful actions against those from within the public service on what appeared to be efforts to subvert investigations so that the truth would never ever come out. And finally there was the third form of answers where those in the government with administrative power in their hands had brought tough actions against those from outside the government who/which persisted in raising the 1MDB questions.

But since there were more than a few parties around from within and outside the country having to suffer the consequences of their persistent questioning, just one single case involving a politician and his lawyer shall be dwelt upon to some extent in this case study. The rest shall perhaps be covered in another case study.

The answers in the form of words are delineated next to be followed by the discussion of the efforts to obstruct justice. The section shall after that come to an end with the discussion on the third form of answers which is intimidation against civil society. At the end of section there is also a bit delineation of intimidation suffered by a party from outside the country and how 1MDB had affected Malaysia as a whole.

\subsection{Words and More Words to Satisfy No One?}

The answers on questions related to the $1 \mathrm{MDB}$ may be categorized on the basis of those where they came from: 1MDB; 1MDB president and chief executive Arul Kanda Kandasamy; government figures; and, some other concerned personalities or parties. Answers coming from 1MDB are dissected to some extent below while for the rest of the parties the samples of the headings of news report with their responses inside are listed out next.

- $1 M D B$ president and group executive director Arul Kanda Kandasamy:

- I'm willing to engage with Pua, $1 \mathrm{MDB}^{\prime}$ 's new chief says (January 16,2015 )

- We gave you facts, all proof with authorities, 1 MDB tells Dr M (June 18, 2015) 
- Pua not interested in the truth, says 1 MDB (August 17, 2015)

- $1 M D B$ chief denies 'spurious' cover-up claims (October 22, 2015)

- Is it mission accomplished for Arul Kanda at 1MDB? (January 11, 2016)

- Cover Story: It is mission accomplished at 1 MDB for an RMC old boy (January 28, 2016)

- Cover Story: The land in Air Itam, Penang (January 28, 2016)

- Cover Story: Status of the asset and debt swap deal with Ipic (January 28, 2016)

- President of Malaysia's embattled 1MDB says my job is done here (March 31, 2016)

- Arul Kanda to Pua's debate challenge: Bring it on! (April 15, 2016)

- Arul Kanda: I never admitted there was fraud (April 28, 2016)

- Arul Kanda: It's no longer possible for me to engage with Tony Pua in a debate (May 18, 2016)

- Arul Kanda pulls out (May 19, 2016)

- Arul Kanda says important announcement on 1 MDB to be made soon (May 05, 2017)

- Prime minister, finance minister and chairman of 1MDB's board of advisors Datuk Seri Najib Tun Razak:

- $1 M D B$ is not bankrupt, says PM Najib (April 8, 2015)

- 1MDB RM42 billion now part of TRX, Bandar Malaysia land bank, says Najib (May 18, 2015)

- Terengganu Investment Authority's RM500m start-up capital 'untrue' - PM Najib (May 28, 2015)

- Stick with me on 1 MDB or resign, Najib tells ministers (June 1, 2015)

- I want answers on 1MDB too, but action must be based on facts, says Najib (June 9, 2015)

- Malaysia's Najib says "conscience clear" as funding scandal festers (December 8, 2015)

- PM Najib : 1MDB's 'real legacy' seen in TRX, Bandar Malaysia (April 12, 2016)

- Deputy finance minister Datuk Chua Tee / deputy finance minister Datuk Ahmad Maslan / second finance minister Datuk Johari Abdul Ghani:

- Chua defends $1 M D B$, says banks' extension on its loan shows confidence in the company (January 29, 2015)

- $B N$ won't be shaken by $1 M D B$ 's issues and will win the next GE, says Ahmad Maslan (March 24, 2015)

- Johari clears the air (February 20, 2017)

Low Taek Jho:

- 'I've nothing to hide': Malaysia's Jho Low breaks silence to deny money laundering allegations (March 12, 2015) 
INTERNATIONAL JOURNAL OF ACADEMIC RESEARCH IN BUSINESS AND SOCIAL SCIENCES

Vol. 8, No. 12, Dec, 2018, E-ISSN: 2222-6990 @ 2018 HRMARS

- Jho Low and the Wolf of Wall Street: how Malaysian businessman 'hooked up DiCaprio' (March 12, 2015)

- Others get away with losing billions, so why pick on me, says Jho Low (April 14, 2015)

- Jho Low denies wrongdoing claims linked to 1MDB (July 14, 2017)

Public Accounts Committee (PAC) chairman, Pulai MP and BN Backbenchers Club finance committee chairman Datuk Nur Jazlan Mohamed:

- A voice in the wilderness (March 6, 2015)

\subsubsection{MDB}

When it concerns the $1 \mathrm{MDB}$ and those closely associated with it, examples of the full texts of their statements to the media include the two found at the very end of writing pieces by Gunasegaram (2013d; 2014b) and another two in theedgemarkets.com which are "1MDB rebuts

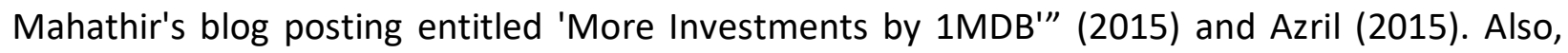
there was a letter from the 1MDB published in the Malaysiakini on 20 September, 2015 (1MDB, 2015).

In late October 2014, something which could be considered odd had also taken place: what appears to be the same piece of writing with the same heading ("1MDB replies to criticisms") is published using two bylines in the very same online publication theedgemarkets.com: one The Edge Financial Daily (31 October, 2014) and the other 1Malaysia Development Bhd Corporate Communications (30 October, 2014). However, note that when word count on the Microsoft tool menu was executed on these writing pieces, differences between the former and the latter are found on a number of "statistics" including the following: words (1941 vs. 1929); lines (42 vs. 48) paragraphs (159 vs. 160). For the former see "1MDB replies to criticism" (2014) and for the latter 1 Malaysia Development Berhad (2014).

Aside from this type of responses where the full media statements and the like issued or attached, there were 1MDB's replies reported in some publications minus the full texts of the statements. The headings of the news reports together with their dates of publication for a sample of this type of responses are as follows:

- $1 M D B$ will not comment on 'speculation, market rumours' (April 24, 2015)

- 1MDB: Wait for outcome of PAC and Auditor-General's reviews (May 18, 2015)

- $1 \mathrm{MDB}$ 'categorically denies' transfer of funds to third party (June 8, 2015)

- Cabinet backed RM5 billion sukuk, says 1MDB (June 16, 2015)

- $\quad$ No attempt to hijack TIA money, says 1MDB (June 17, 2015)

- 1MDB: Pua's recycled allegations that have been answered (August 14, 2015)

- Pua not interested in the truth, says 1MDB (August 17, 2015)

- No end to $1 M D B$, Pua's 'monkey business' (August 17, 2015)

- $1 \mathrm{MDB}$ to Tony Pua: Practise what you preach, quit from PAC (September 10, 2015) 
INTERNATIONAL JOURNAL OF ACADEMIC RESEARCH IN BUSINESS AND SOCIAL SCIENCES

Vol. 8, No. 12, Dec, 2018, E-ISSN: 2222-6990 @ 2018 HRMARS

- $\quad$ MDB lauds PAC's deputy chairman's advice to 'seek proof' before accusing (September 23, 2015)

- 1 MDB tells Pua not to mislead public (October 13, 2015)

- Dr Mahathir's claims show his contempt for investigations, says 1MDB_(December 3, 2015)

- We have explained all to A-G's Department and PAC, says 1MDB (April 4, 2016)

And note also that in the August 14, 2015 news report from theedgemarkets.com whose heading is listed above, there was the following mentioned in its first paragraph (Chee Yuan, 2015): "Controversy-surrounded 1Malaysia Development Bhd (1MDB) today described Petaling Jaya Utara MP Tony Pua as recycling various allegations that had been answered by the firm since January 2015 via 48 press announcements." Also note what was mentioned in a booklet of 79 pages on 1MDB by the federal government's propaganda unit, the Special Affairs Department (Jasa), which was distributed to university students to counter allegations against the Finance Ministry-owned firm ("Putrajaya goes to campuses", 2016): "It says Putrajaya has never shied away from giving answers on $1 \mathrm{MDB}$, adding that the firm itself issued 90 statements to answer various allegations from January to November last year."

But if truth be told such remarks pointing towards 1MDB's active media presence and the sample replies plus the full media statements and the like from 1MDB detailed above were not what took place for so many years prior to the late 2014 onwards! Furthermore, one can also detect some inconsistencies in some of the replies coming from the 1MDB from the late 2014 onwards.

In regard to $1 \mathrm{MDB}^{\prime}$ s reticience for years and years prior to the late 2014, Jose Barrock had this written in late March 2013 in the Kinibiz (Barrock, 2013b):

Last week 1 Malaysia Development Bhd (1MDB) a government owned entity closely linked to premier Najib Razak, had a change at the helm... Surprisingly, no announcements were made, and it was via a news report that the update was disseminated. For a high-profile government-owned body which has made billions of ringgit in investments and issued large amounts of bonds we would have expected more. At about the same time last week, Bloomberg reported that 1MDB had issued US\$3 billion (about RM9.4 billion) in debt papers, on March 19 on the quiet...

And Jose Barrock had more to say as seen in the following which came not long later in the piece: Much of what 1 MDB does is often shrouded in secrecy, and leaves many questions unanswered. Why did it issue bonds at such a favourable rate to buyers? Who is PetroSaudi and what has it to do with it 1MBD? Why the Middle East investors? Why is 1MDB getting government land cheaply and then bringing in foreign partners to develop it? Why the tax concession for developers who undertake projects on these land? Why buy power assets, some of them about to expire?

Later in early April 2013 in another write up in Kinibiz where he made comparison between the 1MDB and Khazanah Nasional, Jose Barrock had this to say (Barrock, 2013c): "... the level of secrecy at $1 M D B$ is hardly seen in corporate Malaysia." And he had two persons quoted in this regard. A so called veteran journalist mentioned: "There are no briefings... company officials are 
not forthcoming with information. This creates much speculation." The other person "a Singaporean fund manager" had pointed out: "In 1MDB's case it seems to be creating its own problems, there is way too much secrecy... be it when bonds are issued, on the coupon rates offered, the take up of bonds... or even the on-goings in the company generally. Honestly it's not often that Khazanah comes across looking so good."

Also note what was mentioned later in December 2014 in The Edge Financial Daily by none other than the then deputy finance minister Datuk Ahmad Maslan who in his reaction to Batu Kawan Umno division deputy chief Datuk Seri Khairuddin Abu Hassan's move to lodge a police report against $1 M D B$ a few days earlier was quoted to say (Chong and Ganesh, 2014): "The company should engage and communicate more clearly. 1MDB has good assets and I am confident there is no problem with that..."

That the 1MDB was rather media shy for years and years prior to the last quarter of 2014 is further substantiated by the following interesting news report in the Free Malaysia Today coming out in mid December 2014 (FMT Reporters, 2014):

While welcoming the move by $1 \mathrm{MDB}$ to be open to any investigations into their affairs, DAP's National Publicity Secretary Tony Pua reminded that the company was unwilling to answer any questions on its alleged improprieties in the past. Commenting on 1MDB's "sudden purported openness" Pua said, "This is despite the fact that prior to the police report, 1MDB had conducted itself in a completely opposite fashion, scrupulously hiding information and avoiding scrutiny over its various controversial transactions." He was referring to the police report a Penang UMNO leader lodged against the company last Friday.

Also, it should be worth noting the following appearing in the same news report:

Pua, who is also Member of Parliament for Petaling Jaya Utara, said that in the past even Prime Minister Najib Razak was tight lipped over queries regarding the US\$2.32 billion in Cayman Islands, only saying that "licensed financial institutions" were managing the funds there... Pua recounted the "many other baffling transactions 1MDB has refused to explain in any detail" about including its US\$1 billion investment in Petrosaudi International, the RM4 billion in SRC International and the "controversial $10 \%$ of proceeds from bonds raised which were paid to Goldman Sachs International as 'certain commissions, fees and expenses'".

As if all this not revealing enough note that in the very last paragraph of the very same news report there was the mentioning of what happened several years earlier in 2011 where Pua was said to have recalled that in two PAC's proceedings, the 1MDB officials had refused to disclose information of any kind leading to "unfruitful" outcomes! And note that this was not quite new information since in late March 2013 in the Kinibiz Pua was quoted to have said the following as what transpired during the 2011 PAC meetings when the 1MDB officials were questioned about the company's dealings with PetroSaudi (Gunasegaram, 2013b): "We questioned them about PetroSaudi and asked for documents but all they gave us was press releases."

Alas, the $1 M D B$ had faced no punishment whatsoever leading to the emergence of a picture that the PAC then had failed to do its job well as far as the 1MDB was concerned. But this was perhaps par for the course when the same lack of action could be detected in the later years coming from 
INTERNATIONAL JOURNAL OF ACADEMIC RESEARCH IN BUSINESS AND SOCIAL SCIENCES Vol. 8, No. 12, Dec, 2018, E-ISSN: 2222-6990 @ 2018 HRMARS

similar other entities such as the Royal Malaysian Police, the MACC and the Attorney General Office.

For details as what took place during the 1MDB's PAC meetings of 2011 and 2012 as reported in 2015 and also as reported shortly after their taking place see Table 1 and Table 2, respectively. In particular, check out the underlined parts. Also note that for the first two in Table 1, the first is from theedgemarkets.com and the second from The Malaysian Insider. As for the last one in Table 1 and all four in Table 2 are sourced from Malaysiakini.

Table 1 PAC meetings on 1MDB in 2011 and 2012 as reported in 2015

\section{March 17, 2015}

"There have been two hearings on 1 MDB by the PAC when the chairman was Azmi Khalid and I was a member of PAC," current PAC chairman Datuk Nur Jazlan Mohamed told reporters today when asked on the status of the Auditor-General's $(A-G)$ investigations on $1 M D B$. However, he noted that despite the hearings being held and attended by $1 \mathrm{MDB}$ founding managing director and chief executive officer Datuk Shahrol Halmi, the previous PAC committee did not table its findings to parliament. (Emphasis added.) (Blemin, 2015)

\section{May 4, 2015}

In 2012, PAC under former chairman and minister Tan Sri Aziz Khalid had probed into 1MDB, adding it was "healthy and balanced". Calling a document "crucial", Azmi said: "We realised that the financial statement for March 2011 is not confidential and is available online. So based on the documents, we found that they (1MBD) have a healthy balanced sheet." PAC had started investigations in November 2011 and arrived at this conclusion based on only one document received out of the seven requested. The other six documents are related to $1 \mathrm{MDB}^{\prime}$ s investments with PetroSaudi International Limited... (Emphasis added.) ("PAC to quiz those", 2015)

\section{May 19, 2015}

The Public Accounts Committee (PAC) is scheduled to question 1Malaysia Development Bhd (1MDB) personnel, beginning today... However, this is not the first time that PAC will be doing so. Back in November 2011, it resolved to investigate $1 \mathrm{MDB}$ following complaints from then opposition leader Anwar Ibrahim on the company's "suspicious" deal with PetroSaudi International... Apart from Anwar's complaint, the PAC hearing, which was held on June 27, 2012, also decided to investigate $1 \mathrm{MDB}$ on Putrajaya's decision to allocate RM1.11 billion for the company under Budget 2012... Seven documents were sought from 1MDB, of which only one - the audited account for 2011, which was already a public document at the time - was made available to PAC. Nurzahid, then listed as the $1 M D B$ senior vice-president, explained to PAC that the other documents could not be furnished because of a non-disclosure agreement with joint-venture partner PetroSaudi International (PSI). Apart from establishing the fact that the auditorgeneral has the right to "sight" the six other documents, PAC didn't pursue the 
matter much further, although DAP's panel member, Petaling Jaya Utara MP Tony Pua did put on record that $1 \mathrm{MDB}^{\prime}$ s decision not to furnish the documents was tantamount to contempt towards the PAC... Then PAC chairperson Azmi Khalid appeared convinced by the explanations provided, telling the press later that $1 M D B^{\prime}$ s financial situation appeared to be financially sound, while noting that some PAC members disagreed. The most obvious dissenter was Pua, who appeared to be the only one to have thoroughly studied 1MDB's 2011 accounts before the meeting and pressed the company's officers on how the numbers were arrived at. However, at almost every stage of the hearing, Pua was faced with an obstacle in form of Rahman Dahlan, who appeared to be keen on defending 1MDB's business decisions and steering discussions away from contentious matters... However, Rahman did ask for Nurzahid to describe 1MDB's five-year plan to the PAC, in order to evaluate the company's cash-flow situation. Nurzahid said this would be provided at a later date. It is understood that PAC never got the five-year plan. (Emphasis added.) (Ong, 2015)

Table 2 PAC meetings on 1MDB in 2011 and 2012 as reported right after

\section{November, 2011}

The Public Accounts Committee (PAC) will haul up 1Malaysia Development Bhd (1MDB) to answer alleged discrepancies in its business dealings with PetroSaudi International Ltd. The committee has finally decided to get cracking on allegations about the discrepancies made five months ago by Opposition Leader Anwar Ibrahim. Anwar in June highlighted $1 M{ }^{2} B$ 's dealings with PetroSaudi, saying that IMDB disposed of investments in its joint venture with PetroSaudi International barely five months after the joint venture was inked. Anwar had written to the PAC then, asking the parliamentary committee to unearth details of 1MDB's RM3.5 billion investment in 1MDB PetroSaudi Ltd and the subsequent RM4.1 billion sale back to PetroSaudi International, recording a profit of RM615 million. "Because there was a letter written by one MP and since the letter was written to PAC, we just want to find out. At least, for the first time, we want hear about the company. We don't know much about it," PAC chairperson Azmi Khalid said today... A PAC source said later that $1 \mathrm{MDB}$, would also be queried on other controversies, among them the RM1.11 billion allocated to the strategic investment agency under the 2012 Budget to redevelop the Sungai Besi air base... The opposition has demanded to know why $1 \mathrm{MDB}$ was being granted such a huge sum when the company was capable of generating its own funds. The PAC source said that 1MDB would also be probed on the RM26 billion Kuala Lumpur International Financial District project. (S.Pathmawathy, 2011a) 
1Malaysia Development Berhad's (1MDB) moneylending to a relatively unknown international firm is being probed by the Public Accounts Committee (PAC), as the agency's actual role is to channel in foreign investment and strategic partnership. PAC deputy chairperson Tan Seng Giaw told reporters that the two-hour meeting today focussed on 1MDB's US\$1 billion (RM3.5 billion) investment in a jointventure with PetroSaudi International Ltd. "It is something like US\$1 billion and we give it to this company and we are not investing but giving it as a loan to them. Can you beat that? "It is supposed to be 1 Malaysia Development Berhad, but this looks like it is 1Malaysia Pinjaman (loan) Berhad!" he exclaimed. 1MDB was summoned today to answer alleged discrepancies in its business dealings with PetroSaudi, specifically into its joint-venture - 1MDB PetroSaudi Limited. Opposition Leader Anwar Ibrahim, in June, questioned 1MDB's dealings with PetroSaudi, saying that IMDB disposed of investments in its joint venture with PetroSaudi barely five months after the strategic partnership was inked. Anwar then asked the Parliament's PAC dig up the details 1MDB's RM3.5 billion investment in 1MDB PetroSaudi Ltd and the subsequent RM4.1 billion sale back to PetroSaudi International, recording a profit of RM615 million. However, it was revealed today that the RM4.1 billion (which translates into US\$1.2 billion) was in fact converted into a loan to PetroSaudi. "The basic problem is (1MDB) has invested in PetroSaudi, which has an office in Cayman Island, which has existed since 2005 but we don't know what sort of company it is (and) how reliable it is," said the Kepong DAP MP. However, 1MDB chief executive officer Shahrol Halmi, who was accompanied by the Economic Planning Unit's (EPU) Rahamat Bivi Yusoff, was not able to provide a "complete explanation" on the matter, said Tan. "But they promise to give some of the documents, they said some are confidential... (but we need them) because we don't know how reliable it (PetroSaudi) is. It is using our money." ... According to a PAC source, the 2009 investment was converted into a loan, that promised an earning of 8.67 percent interest annually, approximately US\$104 million for 11 years, with a corporate guarantee from PetroSaudi. The source said 1MDB explained the decision to convert the investment into a loan was due to "other priorities" at hand. "The aspect of the deal is - the original aspect was 40/60 where 1MDB takes 40 percent and PetroSaudi takes 60 percent. "1MDB invested US\$1 billion and PetroSaudi injected US\$1.5 billion, but in this case PetroSaudi's US\$1.5billion was an injection of assets," he further revealed. A chunk of the PetroSaudi's assets included "a potential oil field in Turkmenistan". However, the $1 M D B$ partner confessed to have never visited the site. "But the oil field - is it worth US\$1.5 billion? They have alleged that they have independent financial reports to say that they are worth at least or more than US\$1.5 billion. "They couldn't answer if these were high risk oil fields project or proven reserve projects which is why we asked for the documents," added the source. Among others, the 1MDB representatives were also vague on providing the committee with PetroSaudi's financial and investment portfolio. "They showed us some press cuttings about 
how strong there are. I mean how can you investment US\$1 billion and not know who your investment partner is? The gist of what they said is that the auditors are fine with it so we should take the auditor's word for it," said the source. However, $1 \mathrm{MDB}$ has been informed to submit the relevant documents to the committee. "Even if PetroSaudi is indeed a very strong company - since when it is 1MDB's mandate to become a moneylender? 'The role of $1 \mathrm{MDB}$ is not to lend money and give interest in returns, even if the interest is profitable, the role of $1 \mathrm{MDB}$ is to bring development into Malaysia not become a moneylender and more so to foreign entity which is of unknown origins," added the source. (S.Pathmawathy, 2011b)

\section{June 2012}

The parliamentary Public Accounts Committee's (PAC) probe into allegations of questionable investment by national investment arm 1Malaysia Development Bhd (1MDB) was stymied by its inability to obtain documents from the company. "Some documents were sought by the PAC, seven altogether, but only one was furnished," its chief Azmi Khalid said at a press conference in Parliament House after chairing the PAC meeting on $1 \mathrm{MDB}$ today. Azmi said the company told the committee that the six documents pertaining to its PetroSaudi fund investments needed the okay of the fund's shareholders... Asked when will the committee expect delivery of the documents he said that the matter depends on PetroSaudi's investors and 1MDB cannot do anything without their okay to release further details. Azmi related that $1 \mathrm{MDB}$ was represented at the meeting by its senior vice-president, accompanied by representatives from the Prime Minister's Office. The sole document furnished by the investment arm to PAC was its financial balance sheet for the year financial ended 2011. The "crucial" document, said Azmi, showed that 1MDB's books were "in order, technically". He said he found the company financials to be sound and its investment registering profit... But Azmi conceded that there are other concerns about the finances of the firm raised by PAC members. He said that $1 M D B$ has been asked to provide answers to the concerns while the Auditor-General's office was also asked to looked into the company finances. Quizzed on what's next in PAC's probe, Azmi said that the committee will decide soon, but said that for now there is nothing yet on its agenda to follow up on. The investment by 1MDB into PetroSaudi was brought to the attention of the committee by opposition parliamentarians who have alleged several irregularities in the million ringgit transaction. Petaling Jaya Utara MP Tony Pua alleged that it is akin to a 'Ponzi Scheme', referring to a recent Wall Street scandal which saw millions lost in bogus investment schemes. The PAC has announced the probe into the investment arm in November last year. (Hazlan Zakaria, 2012)

\section{June 2012}

1Malaysia Development Berhad's (1MDB) accounts are "not as sound" as made out to be, claimed three opposition members of the Public Accounts Committee (PAC). 
This is because the profits shown in the balance sheet submitted by the government's strategic investment arm had been propped up by the re-evaluation of parcels of prime land as well as the injection of loans, said Petaling Jaya Utara DAP MP Tony Pua. At a press conference today, he said PAC chairperson Azmi Khalid claiming that the company is financially sound was an "unfair assessment"... Selayang PKR parliamentarian William Leong reminded Azmi that it is wrong to come to that conclusion when $1 M D B$ had refused to furnish six out of seven documents requested by the PAC. The sole document furnished by the investment arm to PAC was its financial balance sheet for the year financial ended 2011. "One when we have everything required then we can conclude," said Leong with concurrence coming from Tumpat PAS MP Kamaruddin Jaffar... Kamaruddin added that they had expressed their concerns on the issue at yesterday's PAC's meeting and the Auditor-General's office has been asked to look into the company finances. (S.Pathmawathy, 2012)

Aside from the rather muted response for a number of years prior to the late 2014, the so called $1 \mathrm{MDB}^{\prime}$ s rather active media response from the late 2014 onward mentioned earlier is actually not without its hiccup. In other words, within the last few years there were instances where the company or those closely associated with it could have been more responsive. This can be detected by checking out the headings for a sample of news reports that came out in a period of just seven months from early April to early November for the year 2015:

- Time to answer Dr M's allegations, Ku Li tells Najib (April 2, 2015)

- Najib dodges questions on Dr Mahathir's criticism (April 8, 2015)

- Why can't Najib answer simple questions, asks Dr M (April 9, 2015)

- Another Umno lawmaker says Najib must answer Dr Mahathir (April 22, 2015)

- $1 M D B$ snubs investment forum (April 23, 2015)

- Answer claims of false documents, says Dr M (April 24, 2015)

- Najib's continued silence on 1MDB damning, says Pua (April 28, 2015)

- Dear 1MDB, here's what you need to tell Malaysians (May 2 2015)

- Umno MP slams 1MDB for 'elegant silence' on status of RM3.6 billion loan (May 13, 2015)

- Just tell us where is $1 \mathrm{MDB}^{\prime}$ 's money, says Dr M (May 18, 2015)

- More calls for full disclosure from 1MDB (May 26, 2015)

- On live TV, Husni avoids giving answers on Jho Low, 1MDB (June 3, 2015)

- Peeved Pua slams Najib over 1 MDB non-answers (June 9, 2015)

- Security threat a ruse, says Dr M on Najib's no-show (June 9, 2015)

- PM can no longer hide in silence about $1 M D B$, says Azmin (July 21, 2016)

- Zeti: The public deserves answers about 1MDB (September 21, 2015)

- Is Najib's strategy to remain silent like a mouse, asks DAP's Pua (October 6, 2016)

- Nothing to hide means nothing to fear, Nik Nazmi tells 1MDB (October 30, 2015) 
INTERNATIONAL JOURNAL OF ACADEMIC RESEARCH IN BUSINESS AND SOCIAL SCIENCES

Vol. 8, No. 12, Dec, 2018, E-ISSN: 2222-6990 @ 2018 HRMARS

- Najib must appear in Parliament to explain scandals, says Kit Siang (November 6, 2015)

But perhaps all this is not surprising at all - for after all even in the case of federal cabinet members they were not clear themselves on the goings on in 1MDB. Perhaps this can simply be detected by checking out the following headings of a sample of news reports:

- We did ask questions on 1MDB in Cabinet meetings, says Shafie Apdal (May 28, 2015)

- $\quad$ MDB fact sheet given to ministers, but incomplete, says Muhyiddin (July 29, 2015)

- Muhyiddin and I asked about 1 MDB in Cabinet, no one answered, says Shafie (December $8,2015)$

All in all, the 1 MDB has shown marked improvement in the last few years over the matter of giving responses to the questions raised by some parties over its operations compared to what happened in the early years after it was first set up. That said, problems continued to emerge from the late 2014 onwards whereby the 1MDB and those closely associated with it had shown every now and then the tendency to go back to its lack of response mode following some questioning episodes.

But really to be frank there is perhaps no need for any sort of answers coming from the 1MDB and those associated with it! Why? It is simply because of the lack of quality of their so called answers. A case illustrative of such came in the form of April 2015 television interview given by Datuk Seri Najib Razak the then prime minister who was also the one holding the post finance minister and chairman of 1MDB's board of advisors.

As stated in The Malaysian Insider (Commentary by The Malaysian Insider, 2015b): "The early consensus among viewers and those who aired their views in Facebook and Twitter postings is that Najib did not quite address questions raised by Dr Mahathir or opposition lawmakers, or even among ordinary Malaysians." In particular as mentioned in the very same news report:

There was no mention of his ties with businessman Low Taek Jho, who has been linked to the government company that has some RM42 billion in debts. Najib repeated that 1MDB's assets were more than its debts and said its cash pile abroad would be returned when the time was right. He did not address why a company with that cash pile would need a government standby credit or loan to pay off the RM2 billion that was due last year but had its repayment time extended to February. Nor did Najib explain the issue of his family's fortune which prompted his siblings to issue a statement that expressed concern about their father, former prime minister Tun Abdul Razak Hussein's reputation being tainted.

Worse comment came from Khairie Hisyam of the then Kinibiz (Khairie Hisyam, 2015):

Late evening on April 9, Malaysians turned on their television sets with great anticipation. Prime Minister Najib Abdul Razak, under heavy fire by critics on various issues, was to speak in a landmark - albeit pre-recorded - interview to address the criticism, not least of which came from former premier Dr Mahathir Mohamad. However, Najib's lips repeated tired 
statements and sidestepped critical issues. And the interviewer, so easily and prematurely satisfied with those answers, did Malaysians no favours either.

Regarding the $1 \mathrm{MDB}$ raised in the interview session in particular, Khairie had this to say:

On controversial 1Malaysia Development Bhd (1MDB), the interviewer started off promisingly by asking for comment on claims that 1MDB's transactions were orchestrated by "certain personalities" - no doubt a reference to businessman Jho Low. But things only went downhill from there. The question was left unaddressed. Instead Najib began by reiterating how the Ministry of Finance only injected RM1 million into 1MDB, necessitating the selfstyled strategic development company to borrow to grow. The crux of Najib's defence: $1 \mathrm{MDB}^{\prime}$ 's assets exceed its liabilities. Give $1 \mathrm{MDB}$ time to develop or liquidate its assets. Let the auditor-general's probe and that of the Public Accounts Committee run their course - though no firm deadline was given.

And finally note the comments on the television interview made by Datuk Nur Jazlan Mohamed an MP on the same side as the then prime minister who happened to be the then Public Accounts Committee (PAC) chairman as revealed in themalaysianinsider.com (Zachariah, 2015b): "To me, it didn't kill any subsequent criticisms and speculation, so it didn't work. Give an explanation which will satisfy the people and kill the speculation and innuendos."

And yet such a good advice was easy to utter and difficult to see reflected in reality. Note a sample of the headings of news reports covering a period from April 2015 to June 2016 following that disaster of an interview:

- $\quad$ Stop giving half-baked answers on RM42 billion debt, Pua tells 1MDB (June 4, 2015)

- Arul Kanda's evasive answers destroying $1 \mathrm{MDB}$, Najib's credibility, says DAP (June 19, 2015)

- Pua slams 1 MDB for rehashed, recycled answers (August 18, 2015)

- Tony Pua rubbishes Arul Kanda's 'reckless' claim on 1MDB deals (January 14, 2016)

- Pua tells $1 M D B$ to stop making 'an ass of yourself' (April 5, 2016)

- DAP's Pua accuses Arul Kanda of 'covering up' 1MDB-Aabar BVI scam (April 13, 2016)

In addition to the incapability of giving direct answers to the questions that people had in their mind, the lack of quality of answers provided by the 1MDB side may also come out in other forms. Appendix 1 provides some examples that come with the following headings:

- When the answers to the questions bring in more questions!

- When the answers had to be retracted with an apology ensued next...

- When the answers were proven to be shamefully false...

- When even the former $1 \mathrm{MDB}$ spokesperson himself later on when he was no longer part of the federal cabinet had to ask some quite basic questions!

- When the answers had promptly arrived but the one answering came not from the 1MDB or one of the insiders but instead an outsider - from overseas!

In the whole, as can be seen in the Appendix 1, the answers from various parties over the years appear to have failed to clarify matters and instead brought more questions and some other unintended reactions. But really the lack of good and full answers was not the only dissatisfaction 
that those from inside and outside the country had had to confront over the years. Another source of much if not greater frustration and deep concerns among many was the fact that for some years prior to GE14 on May 9, 2018 when the government changed hands the authorities then had committed just about everything to quash investigations conducted by various government entities. And inevitably this had led many to conclude that these were the efforts to ensure the truth and nothing but the truth shall never get the chance to come out to the open! For certain nothing good could be expected to come from this kind of activities - except perhaps to the perpetrators of such acts and even this had failed to last long following the surprised outcome of the GE14!

\subsection{Obstruction of Justice is the Answer!}

If truth be told Malaysia from some time in 2015 to GE14 was in a pretty bewildering state. And this could be understood by the fact that during those years the country had to confront episode after episode of those helming the country taking the liberty to do all that they could to subvert justice as far as investigations on the goings on in the $1 \mathrm{MDB}$ and related parties were concerned. In short, and in a manner of speaking, this was nothing more than a form of answers by the concerned parties to all the questions that had been raised over the years and which were detailed out to some extent in the previous section on questions.

To parties at the receiving end of the efforts to obstruct justice it must have been quite a trial. But it was not easy too for the rest of the Malaysian people who earlier thought that such a thing could only take place in other countries less developed than Malaysia and where democracy had never really taken its roots. And yet such attacks had indeed taken place as can be detected in the samples of headings of news reports that were concerned with the three important institutions in the country:

\section{Federal Cabinet:}

- Salleh: Comply or resign (May 11, 2015)

- Give Cabinet more time to study 1MDB roadmap, says Kit Siang (May 29, 2015)

- Stick with me on $1 \mathrm{MDB}$ or resign, Najib tells ministers (June 1, 2015)

- Cabinet unable to deal with 1 MDB mess, says Dr M (June 3, 2015)

\section{Parliament:}

- Parliament rejects qns on TRX and calls by Tun M for Najib to resign (May 18, 2015)

- Speaker must allow debates to redeem Dewan Rakyat's honour, say lawyers (May 25, 2015)

- Pandikar: Rejected 1MDB questions did not comply with Standing Orders (July 27, 2017)

- Parliament shoots down Rafizi's bill for new law (November 4, 2015)

\section{MACC personalities:}

- MACC denies reports that ex anti-graft adviser leaked 1MDB info (July 21, 2015) 
- Dr Mahathir questions fate of MACC chief (January 15, 2016)

To get to know in some details the efforts by the authorities to obstruct justice, there is a need to go through remarks coming from a number of parties from inside and outside the country. And in doing so too, it should be a good reminder to all that such obstruction should have never taken place and must never ever be allowed to recur - in case Malaysia continue to want to be in one piece to march forward into the world like many other countries with the confidence that they have not just the vision but also the right and strong foundation in doing so. Hence, the concerned parties need to suffer sufficient punishment so that it would be good lessons to all and particularly the future generations. (Unfortunately from the look of things since GE14, the new government formed with its New Malaysia motto has not shown the slightest interest in doing the necessary! Why? Is it because part of the so called Malaysian Story is that whoever is in power is forever interfering with the government machinery? Perhaps this subject matter shall be touched on in another case study...)

\subsubsection{Tony Pua (July 2017)}

The first crystal clear remark came from Tony Pua who in July 2017 media statement (in response to the then prime minister's opening speech at Invest Malaysia 2017 described later in Part II of the case study) had said ("Why has Najib refused", 2017):

What's more, while the Prime Minister wants to take credit to initiating investigations into the 1MDB fiasco, he failed to highlight the fact that he replaced the Public Accounts Committee Chairman with Dato' Hassan Ariffin who refused to summon the Prime Minister for questioning because he had to "cari makan". The Prime Minister also 'retired' an Attorney-General who was about to prosecute him and he refused to instruct 1MDB to comply fully with the Auditor-General after the company failed to provide any of its overseas bank records and statements for audit.

\subsubsection{Lim Kit Siang (January 2016)}

Compared to Tony Pua in July 2017, Lim Kit Siang had said so much more in his rebuff of the remark made by the then attorney general during the launching of Legal Year 2016 in January 2016. In a piece published in Malaysiakini, he mentioned (Kit Siang, 2016):

Apandi's continued pretence that there had been no interference in the investigations into $1 \mathrm{MDB}$ flies in the face of reality and does not sit well with his appointment as AG, which came about as a result of the sudden and shocking sacking of his predecessor, Abdul Gani Patail, on 'the Day of the Long Knives' on July 28 last year. From that day, PM Najib had launched his "purge" of the government - which involved the sacking of Abdul Gani as AG, Muhyiddin Yassin as deputy prime minister, Mohd Shafie Apdal as rural and regional development minister, and the subsequent purges and punitive actions against recalcitrant key officers in various government investigating/enforcement agencies.

Next, Lim had delineated the various efforts to obstruct justice in crystal clear manner. As he put it:

How can Apandi glibly claim that there had been no interference in the investigations into $1 \mathrm{MDB}$ when he could not explain the following events: 
- The sudden sacking of Abdul Gani as AG when he was some three months before his compulsory retirement, while the "health" excuse given was a most spurious one which no one believed;

- The dissolution of the multi-agency $1 M D B$ special task force headed by Abdul Gani as AG and comprising the Bank Negara governor, the inspector-general of police and the Malaysian Anti-Corruption Commission (MACC) chief commissioner;

- The sabotage for over three months of the investigation by the parliamentary Public Accounts Committee (PAC) into the 1 MDB by the removal of its chairperson and three other members by the expedient of appointing them as minister and deputy ministers; and

- The sudden transfer or arrest of key officers in AG's Chambers, the police, Bank Negara and the MACC involved in 1 MDB investigations which, as Thiru described correctly, were "a subversion of the administration of justice."

\subsubsection{Rash Bhattasharjee (January 2016)}

In The Edge Malaysia Weekly, the associate editor to The Edge Malaysia had this to say in his review of political developments in Malaysia for 2015 (Bhattasharjee, 2016):

With damaging allegations of financial improprieties swirling around the fund, multiple investigations involving key government institutions were initiated. In March, a special task force involving the Inspector General of Police, Malaysian Anti-Corruption Commission (MACC), Attorney-General's Chambers and the police force began its probe into the fund's workings and its RM42 billion debt. As public scrutiny of the affair intensified, Parliament's Public Accounts Committee launched its own enquiry. Then in June, Bank Negara Malaysia made a separate move to investigate whether the fund had violated the central bank's rules.

Not long later he revealed:

The 1MDB controversy fuelled a political storm within the government fold, led by former prime minister Tun Dr Mahathir Mohamad, who turned from being Najib's mentor to his implacable opponent. Among Cabinet members, criticism from Najib's deputy Tan Sri Muhyiddin Yassin, Rural and Regional Development Minister Datuk Seri Shafie Apdal and others boiled over into a Cabinet reshuffle in July. Home Minister Datuk Seri Ahmad Zahid Hamidi rose to become Najib's new deputy... At the same time, Attorney-General Tan Sri Abdul Gani Patail was replaced just two months short of his official retirement... The special task force investigating $1 \mathrm{MDB}$ was renamed in early August, and the Attorney-General's Chambers, now headed by former Federal Court judge Tan Sri Mohamad Apandi Ali, issued a statement that it would not be investigating the fund, but looking at tax evasion and illegal fund flows.

\subsubsection{Datuk Tuan Ibrahim Tuan Man (October 2015)}

The Islamist party's deputy president had lambasted the then attorney general for what he believed to be his inaction towards the call by the Council of Malay Rulers on 1MDB's investigation to be done swiftly. Related to this he was quoted to say in The Malaysian Insider ("A-G not as sensitive as Malay Rulers", 2015): "With many whose fates have been changed 
because of $1 \mathrm{MDB}$, however, $1 \mathrm{MDB}$ and Najib still stand strong because the A-G cannot smell any problems with $1 \mathrm{MDB}$. It is clear that the Attorney-General's nose is not as sensitive as the nose of the Malay Rulers who are also urging for the 1MDB crisis to be resolved quickly." Regarding "many whose fates have been changed", the same news report had this to say:

Tuan Ibrahim said those whose lives had changed includes that of former deputy prime minister Tan Sri Muhyiddin Yassin and minister Datuk Seri Shafie Apdal, who were sacked from Cabinet after publicly criticising Najib and 1 MDB. He noted that even the former A-G Tan Sri Abdul Gani Patail was removed from his post and replaced with Apandi, during the investigation into $1 M D B$ by the special task force headed by the former. The special task force consisted of the A-G's Chambers, the Malaysian Anti-Corruption Commission (MACC), Bank Negara Malaysia and also the police.

And there were still more cases of those "whose fates have changed" as seen in the following quotation coming from Tuan Ibrahim:

No only that, there was also the strange transfers of the deputy director of Bukit Aman's special branch Datuk Abdul Hamid Bador and MACC investigating officers to the Prime Minister's Department, the appointment appointing four members of the Public Accounts Committee (PAC) to the Cabinet, the sacking of law officer Jessica Gurmeet Kaur and the dissolution of the 1MDB special task force. The matter did not stop there. Now 1MDB critics Datuk Khairuddin Abu Hassan and Matthias Chang have been detained under Sosma and were charged with attempts to sabotage the country's economy.

Akin to a big slap in the face and a kick on the butt for the attorney general, Tuan Ibrahim had further pointed out the "mystifying" case of the former claiming that Bank Negara had been reckless in making certain accusations against $1 \mathrm{MDB}$ while failing to blame the company $1 \mathrm{MDB}$ on borrowing lots of money leading to the occurrence of substantial debts. And as if his rage against the injustice of it all had spilled over, he was quoted to say: "The 'fantastic' thing is that up till now, 1MDB has yet to face the PAC and the prime minister has yet to be questioned by the police or MACC. If these incidents are used as a benchmark of $1 \mathrm{MDB}$, it can be counted as the nation's biggest crisis."

It is notable just a few weeks later in early November 2015 in another devastating attack against the authorities, Tuan Ibrahim was said to have raised the matter of how the "1MDB's troubles" had affected national institutions and caused damage to the economy and ringgit ("Don't use 1MDB debate", 2015). Related to this he was quoted to say in The Malaysian Insider: "The integrity of Bank Negara is questioned. The disrupted probe into 1MDB has caused the MACC, police and Attorney-General's Chambers to continue to be seen as controlled and not free. This causes the collapse of the check and balance system on those given the mandate to govern the country." As if all this was not bad enough, there was something else happening too. As mentioned in the same news report: "Tuan Ibrahim said while those who reported and questioned 1MDB were "hunted" by the authorities, those allegedly involved with or had links to the firm debt-ridden have yet to be interrogated." He in relation to this was quoted to say: 
Among them are Najib, Jho Low (businessman Low Taek Jho), (SRC International managing director) Nik Faisal Arif Kamil and (SRC director) Datuk Suboh Md Yasin. On October 22, Najib said Nik Faisal and Suboh are making plans to be interviewed by MACC. But until today, there is nothing. The same is with Jho Low. It seems like there is no authority that has the courage to call him up to give statements, including the new PAC chairman Datuk Hasan Arifin.

\subsubsection{Datuk Seri Mohamed Azmin Ali (August 2015)}

In August 2015 the following was stated out early on in a news report by The Malaysian Insider ("Revelations by BN spokeman", 2015):

Datuk Seri Najib Razak "deliberately interfered" with the 1Malaysia Development Bhd (1MDB) investigations, going by revelations from Barisan Nasional's (BN) communications director, PKR deputy president Mohamed Azmin Ali said today. He said BN strategic communications director Datuk Abdul Rahman Dahlan's interview in The Sunday Star yesterday showed Najib had resorted to the "drastic action" to "save his own skin".

And the PKR deputy president who was also Selangor Menteri Besar Mohamed Azmin was next quoted to say:

From Rahman's account, the prime minister unleashed 'a flurry of action' in order to prevent himself from being prosecuted. We take it that this 'flurry of action' refers to the PM sacking Tan Sri Muhyiddin Yassin and four ministers, replacing at lightning speed the attorney-general Tan Sri Gani Patail, disbanding the 1MDB task force and presumably ordering the IGP to unleash his own 'flurry of action' - raiding, arresting and transfer of Malaysian AntiCorruption Commission (MACC) officers and interrogating Bank Negara personnel... To my mind, such an interference may amount to criminal acts both under the Penal Code and the MACC Act (Section 186 and Section 48 respectively).

Perhaps it would be worth noting that in the last few lines of the same news report, there were some details provided on the so called 1MDB task force that Azmin had actually mentioned and also on some other acts of subverting investigation which he had failed to account for. In regard to the latter, there was one involving the parliamentary Public Accounts Committee headed then by the parliamentarian Nur Jazlan Mohamed. As stated in the news report:

The task force was announced soon after The Wall Street Journal reported that RM2.6 billion had been put into Najib's personal bank accounts. Its disbandment followed a string of events which critics say showed Najib's attempt to cover up the 1MDB scandal, as well as the probe into the funds in his accounts which he said was a political donation. Among these moves were changing the A-G in the midst of the probe, and a Cabinet reshuffle which ejected ministers critical of $1 \mathrm{MDB}$. The reshuffle also resulted in the suspension of the Public Accounts Committee which was conducting its own hearings on 1MDB. This was followed by the questioning of anti-graft officers for allegedly leaking official information on the 1MDB probe. 
And in the interest of making it clear as to how did the so called task force mentioned by Lim Kit Siang, Rash Bhattasharjee, Tuan Ibrahim and Azmin above get to be disbanded, what was raised by Tony Pua later in March 2017 in his open letter to the second finance minister Johari Abdul Ghani would be worth looking into. As reported in theedgemarkets.com (Murugiah, 2017):

Pua said the biggest farce must be the "Super-Taskforce" investigating 1MDB comprising of the Attorney-General, the Inspector-General of Police, the MACC Chief Commissioner and the Bank Negara Governor set up by the Prime Minister himself. "Did you forget that just as the then Attorney-General discovered shenanigans relating to the Prime Minister, he was promptly "retired" on spurious 'health' reasons? "As if on queue (sic), the new AttorneyGeneral effectively dissolved the "Super-Taskforce" and even went to the extent of instructing the MACC to stop any further investigations on the matter," wrote Pua.

And perhaps to make the sad, sad saga to be more revolting than it already was check out what Tony Pua mentioned just before he said all that above revealing more problems with the 1MDB investigations:

"You supported your claim by saying the Auditor-General and the PAC could not point to anything specifically wrong with $1 \mathrm{MDB}$. "Again, I pointed to specific sections of the PAC Report which clearly concluded that the $1 \mathrm{MDB}$ top management has on dozens of occasions - lied and misled the Board of Directors, defied the decisions of the Board or worse, acted without the Board's authority, all of which are legal offences. "The PAC even asked the authorities to investigate the CEO, Datuk Shahrol Halmi and other officers involved for the above wrongdoings. However, a year later, Datuk Shahrol Halmi remains comfortably as of today, a Director of PEMANDU agency in the Prime Minister's Department," said Pua. He said that Johari in an open letter to him had written that "as far as the government is concerned, there is nothing to hide and nothing to cover up." "Then, I ask you, if so, why do you not propose for the Cabinet refusing to declassify the 'harmless' Auditor-General's Report?

It appears that this remark coming from Pua gives information on additional two issues in regard to the $1 \mathrm{MDB}$ investigations. And one of these two is concerned with the audit report on 1MDB issued by the Auditor General which had been placed under Official Secrets Act (OSA). Really what the authorities did was just outright disgusting. And what they did is a topic which could have been discussed under the heading PAC report at the end of the penultimate section of this case study. But instead it shall be covered in another case study that is concerned with the various matters of national or overall governance whereupon the case of corporate governance failure of government linked entities such as $1 \mathrm{MDB}$ may be connected to. By doing so in that other case study it is hoped that the detailing out of what happened under that very topic could assist in crystallizing the goal of that particular case study - as opposed to the present one focusing on issues that are related to corporate governance in $1 \mathrm{MDB}$ - which is related to the goings on in Malaysia's governance as a whole within which the corporate governance in 1MDB may be located.

In the world that we live today where many things local and global are hard to separate, all that mentioned by the various personalities above had found their resonance in a piece by Randeep Ramesh published in late July 2016 in the British newspaper The Guardian. But first note the time 
line prior to the onset of the numerous efforts by the Malaysian authorities to obstruct justice as revealed in the superb write up (Ramesh, 2016):

In January 2015, Tong, Rewcastle Brown and Justo met in a five-star Bangkok hotel, the Fullerton. Tong booked a conference room, and brought a number of IT experts, as well as the editor of The Edge, Kay Tat. At the meeting, Justo laid out the 1MDB joint venture, making the same claims that the US Department of Justice would set out 18 months later: namely that hundreds of millions of dollars that were intended for economic development in Malaysia had instead been diverted into a Seychelles-based company. The man at the centre of the transaction was alleged to be Najib's adviser and family friend, Jho Low. It was a potentially huge scoop. Tong agreed to pay Justo US\$2m. Tong and Rewcastle Brown were immediately handed disk drives with the data... Rewcastle Brown finally had the documents she had been chasing for 18 months. On 28 February 2015, Rewcastle Brown posted the first big story online - under a typically unrestrained headline: "HEIST OF THE CENTURY!" ... The impact of the article was felt around the world... While researching the story, Rewcastle Brown had teamed up with the Sunday Times... The paper ran an interview with Mahathir, the former Malaysian prime minister, who called for an immediate investigation and a full audit... In Malaysia, the response was immediate... Najib bowed to the inevitable and ordered investigations by the country's auditor general and the parliamentary accounts committee. Soon, the country's central bank and anti-corruption agency were also looking at 1MDB... Then, on 2 July, Rewcastle Brown and the Wall Street Journal reported that Malaysian government investigators had discovered that US\$681m from banks, agencies and companies with ties to 1 MDB had been deposited in Najib's private accounts in 2013... Najib was now at the centre of a corruption probe relating to allegations that billions of dollars had disappeared from a Malaysian investment fund he controlled. Deputy Prime Minister Muhyiddin Yassin, once a supporter of Najib, publicly called on him to answer questions about the fund. It seemed that Najib was cornered.

And next came the detailing out of efforts by the authorities to obstruct justice:

On the morning of Monday 28 July, the attorney general, Abdul Gani Patail - a party loyalist who had previously gone after the prime minister's opponents - arrived at his office expecting to finalise corruption charges against Najib. The indictment, which Rewcastle Brown later obtained and published, would have charged the prime minister with corruption resulting from the investigations into $1 \mathrm{MDB}$. The attorney general never got to press those charges. On reaching his office, he was summarily dismissed by a civil servant. In a public statement, Najib said the country's top legal officer was too ill to continue in the role. Also relieved of their posts were the head of special branch and the deputy prime minister. Meanwhile, four members of the investigating parliamentary accounts committee were promoted, without any choice, to cabinet positions, which left them with no power to continue investigating, and the committee's work was declared suspended. The next day, a mysterious fire swept through police headquarters, where records of white-collar crimes were kept. It seemed that Najib was in control again. 
While efforts to obstruct justice went full scale within Malaysia there was nothing to worry about as far as the investigation and the related actions taking place overseas were concerned. And this was well noted in the very same The Guardian piece:

The DoJ filing was released at a critical moment for democracy in Malaysia. On 1 August, a draconian national security act introduced by Najib comes into force - allowing the Malaysian government to establish martial law in any designated geographic area. The law will dramatically expand the powers of Malaysia's security forces - allowing for arrests, searches and seizures without warrants and the bulldozing of buildings. But in the rest of the world, investigations into the sprawling corruption scandal are continuing to expand. In Switzerland, the US justice department identified RBS Coutts and Rothschild Bank as conduits for transactions in the corruption complaint. The Swiss attorney general is probing the billiondollar fraud. The banks declined to comment when contacted by the Guardian. Singapore found "lapses and weaknesses" in anti-money-laundering controls at major banks. For the first time in the island state's history, the authorities shut down a merchant bank. In April the United Arab Emirates froze hundreds of millions of dollars in accounts held by alleged conspirators in the $1 \mathrm{MDB}$ fraud and banned the account holders from travelling abroad.

The contrasting situations inside Malaysia versus what took place in the United States were depicted well in a write up by Ahmad Naqib Idris which was published in The Edge Financial Daily just a week prior to the publication of The Guardian piece and it concerned a press conference given the day before at the DAP's headquarters in Kuala Lumpur. Note what appeared in the first few lines of Ahmad Naqib's write up (Ahmad Naqib, 2016):

Opposition lawmakers are calling for a special parliament meeting before National Day to establish a Royal Commission of Inquiry $(\mathrm{RCl})$ to investigate 1Malaysia Development Bhd (1MDB) and Prime Minister Datuk Seri Najib Razak, following news that the US government had initiated civil suits to seize assets linked to 1MDB. DAP parliamentary leader Lim Kit Siang said the announcement made on the invocation of the Kleptocracy Asset Recovery Initiative in Washington on Wednesday had brought "shame and sorrow" to Malaysia's name.

Also note that in the same news report Lim Kit Siang was quoted to say at the press conference: "Yesterday (Wednesday) morning, when it was reported that the US authorities were set to seize assets linked to $1 \mathrm{MDB}$ 'in the largest asset seizure in US history' in the war against global corruption, I asked whether yesterday's cabinet meeting had discussed the breaking news in the US." And Tony Pua who was there in his capacity as the then DAP's publicity secretary was also quoted to say: "We have a situation where the US has already filed charges of massive theft and misappropriation against 1MDB. But in Malaysia, they say there's no misappropriation. It is a ridiculous situation. The Malaysian government must admit that the money is missing and stolen." Next, Tony Pua was reported to say that the then prime minister Najib "... must instruct the police and the Malaysian Anti-Corruption Commission to follow the leads provided by the US Department of Justice to charge all the relevant parties "who have stolen billions from Malaysians"." Related to this, he was quoted to say: "We call upon Datuk Seri Najib to chastise our local regulatory authorities for their ineptitude in getting to the bottom of the scandal, which isn't only the largest in the history of Malaysia, but also has set the ignominious record of being the largest seizure in the history of US." 


\subsection{Intimidation Anyone?}

On the face of persistent questioning (and other related efforts) regarding the 1MDB and related matters by a number of parties from both inside and outside the country, the authorities had come down hard on a number of them comprising of both individuals and organizations. This may easily be detected from the samples of headings of news reports for three prominent sides which/who had to undergo much attacks:

\section{Media:}

- The Edge owner attacked because he criticised 1MDB, says Dr M (February 4, 2015)

- Demonising critics shows 'all is not well with $1 \mathrm{MDB}^{\prime}$ ', says Dr M (February 5, 2015)

- The Edge boss serves Jho Low notice over attacks (February 6, 2015)

- Tong defaming me, Jho Low hits back (February 8, 2015)

- Shadow of 1 MDB lurks behind TMI arrests? (March 31, 2015)

- More flowers and a protest at The Edge, TMI (April 3, 2015)

- Authorities zoom in on Edge group owner? (April 17, 2015)

- Action against journalists a form of intimidation, says Dr M (May 11, 2015)

- The Edge warned over reporting 'tampered' information on 1MDB (June 24, 2015)

- Zahid's threats against The Edge, TMI reek of intimidation, says group (June 25, 2015)

- Suspension of The Edge will undermine work of 1MDB task force, says PKR lawmaker (July 24, 2015)

- Najib sues PAS publication for linking stepson to 1 MDB (March 20, 2015)

- KiniTV, two directors to be charged (November 18, 2016)

Tun Dr. Mahathir:

- Cops cut off Dr M after mentioning Jho Low (June 5, 2015)

- My 'friend' warned me to stop attacking Najib, says Dr M (June 5, 2015)

- Expect more victims of $1 M D B$, including Dr Mahathir, says Kit Siang (October 23, 2015)

- I will continue to ask Najib to resign, it is my right, says Dr Mahathir (November 13, 2015)

- Najib ticked me off over 1MDB, RM2.6 bil, Mukhriz tells supporters (February 11, 2016)

\section{Tony Pua:}

- DAP backs Pua's post in PAC from critics (June 30, 2015)

- $1 M D B$ to Tony Pua: Practise what you preach, quit from PAC (September 10, 2015)

- PAC to discuss Tony Pua's future at first meeting, says new chairman (October 19, 2015)

- It's Najib, not me, who should resign over 1 MDB conflict of interest, says Tony Pua (October 30, 2015) 
- DAP's Pua stands by video comments, will not retract statement (April 12, 2017)

Also note that in one single paragraph in the late July 2016 piece published in the newspaper The Guardian mentioned earlier the tactics of the concerned parties in intimidating The Edge from pursuing the truth concerning the $1 \mathrm{MDB}$ was depicted quite well - and all that described took place in the first half of 2015 following the revelations by Sarawak Report in late February 2015 on how US\$700m had disappeared from the 1MDB joint venture and found its way into various offshore companies and Swiss bank accounts. As noted in The Guardian (Ramesh, 2016):

Najib tightened his grip on power. As prime minister and finance minister, he wielded enormous authority: in April, the government pushed through harsh penalties and restrictions on free speech, particularly on social media. Five executives of Tong's The Edge Media Group - which had also published details of the PetroSaudi deal - were arrested for sedition. The government also introduced a new law, ostensibly aimed at terrorists, which allowed suspects to be detained indefinitely. In July 2015, The Edge Weekly was banned from publishing.

In early January 2016 which was six months prior to the Guardian piece, Rash Bhattasharjee in The Edge Malaysia Weekly gave a review of the 2015 political developments as mentioned above. Regarding all that had happened concerning the $1 \mathrm{MDB}$, he mentioned among others the following on how the media had been impacted (Bhattasharjee, 2016):

To contain the fallout from a stream of damaging exposés about the fund's management, the government restricted access to information about it, in particular the Sarawak Report website... The same month, two publications of the Edge Media Group - The Edge Weekly and The Edge Financial Daily - that had diligently pursued the 1MDB story were suspended for three months by the Home Ministry. The High Court however ruled that the order was defective. The government is appealing the decision.

And in addition to media organization The Edge, a number of politicians had to undergo one form of intimidation or another. Noted Rash Bhattasharjee in the very same early January 2016 write up:

In Parliament, debate on the fund's operations raged as opposition leaders demanded a full accounting of the affair. DAP parliamentary leader Lim Kit Siang was among the casualties, and was suspended from Parliament for six months in late October. His offence was to criticise what he called the lack of seriousness shown in the investigation into the affairs of the investment fund, which the Speaker and his deputy took offence to. Former MCA president Tun Dr Ling Liong Sik joined the fray by supporting Mahathir's call for Najib to quit the prime minister's post. Ling reportedly said, "I agree with Mahathir. Because he (Najib) has taken people's money and put it in his own personal accounts." After weeks of exchanges between Ling and Najib's lawyer, he finally sued Ling for defamation... Langkawi Wanita Umno leader Anina Saadudin was sacked from the party when she filed a suit to reclaim a portion of the RM2.6 billion donation that was deposited into Najib's personal accounts. Gopeng Umno Wanita chief Datuk Hamidah Osman was similarly sacked for calling for Najib's resignation. A more dramatic case involved former Umno division chief Datuk Khairuddin Abu Hassan who was sacked, then arrested with his lawyer Matthias Chang under the 
INTERNATIONAL JOURNAL OF ACADEMIC RESEARCH IN BUSINESS AND SOCIAL SCIENCES Vol. 8, No. 12, Dec, 2018, E-ISSN: $2222-6990$ @ 2018 HRMARS

Security Offences (Special Measures) Act, for allegedly attempting to overthrow the government. (Emphasis added.)

Note that around the same time that Rash Bhattasharjee had written these words, Lim Kit Siang had demanded accountability from the then attorney general on a number of his "major lapses and misjudgments" - which for many may be nothing more than efforts by the attorney general office to intimidate the people. And Lim Kit Siang had listed these out to include the following (Kit Siang, 2016):

- The slew of prosecutions of MPs, opposition leaders and social activists under a variety of draconian laws - including invoking the Security Offences (Special Measures) Act (Sosma) when Parliament had been given an assurance that such draconian measures were aimed only against terrorists; and

- The most pernicious and iniquitous legislation in the form of the National Security Council Bill which usurps the constitutional powers of the Yang di-Pertuan Agong, the cabinet, the Sarawak and Sabah state governments - as promised in the Malaysia Agreement 1963 and the 11 state governments in the peninsula, thus paving way for a prime ministerial dictatorship.

On that second bullet point raised by Lim Kit Siang there seem to be much to be worried about. Note the following coming from Rash Bhattasharjee in the last few lines of his fine The Edge Malaysia Weekly piece mentioned earlier (Bhattasharjee, 2016):

What the direction of events on the national stage in the year ahead can be will depend on many factors. But some indication of the seriousness of the current situation can be gleaned from the passing of the National Security Council Bill at midnight on the last day of the parliamentary sitting for the year. The proposed law, which is now before the Senate, allows the prime minister as the chairman of the council to declare any area a security area, where "emergency-like" conditions can be imposed. That could prove to be a powerful card to hold in a tight spot.

As for the NGO Suara Rakyat Malaysia (Suaram) director Kua Kia Soong in a news report in The Malaysian Insider on the occasion of the release of the NGO's 2015 report in Kuala Lumpur, he was quoted to say ("Malaysia turning into police state", 2015): "We are undergoing a political transformation into a police state in this country. We are turning into a degraded society where important and valued concepts like national harmony and parliamentary democracy have been degraded according to the way the government wants to interpret it." And on the National Security Council Bill in particular, he was quoted to say:

A former anti-corruption activist turned minister said we should have trust in the government that it will not be abused. But we know that in passing the Internal Security Act, the country's second prime minister also said it will never be abused. But we know what happened in 1987 with Ops Lalang, where I was also a victim. So I don't think the value of his words stand very high.

And from rights activist and lawyer Datuk Ambiga Sreenevasan who was among those who attended the launch of the Suaram 2015 report, she was quoted to say in the same news report: "We don't treat people very well in Malaysia, we don't value basic fundamental rights of liberty 
and life. And they dropped a nuclear bomb on us by introducing the National Security Council Bill. How did our ministers allow this legislation to go through?"

All in all, the National Security Council Bill is just the latest tool among the paraphernalia used over so many decades to bring fear to the Malaysian people. Notwithstanding its potential to be quite bestial against many parties what has always been around and is just as bad if not worse from the public perspective is that which a former senator S. Ramakrishnan had mentioned in a letter published in the Malaysiakini in late July 2015 (Ramakrishnan, 2015):

The silence and apparent collusion of law enforcement agencies like Bank Negara Malaysia, the Attorney-General's Chambers, the police and the Malaysian Anti-Corruption Commission in the increasing number of criminal breach of trust episodes, while whistleblowers get reprimanded, shows the lack of governance and a culture of blind obedience prevalent in the civil service. ... When billions of ringgit vanished, there was no red flag raised by any of the law enforcement agencies. If not for the independent business newspaper, The Edge, opposition lawmakers and civil rights groups who acted as whistleblowers, the RM42 billion debts incurred by 1 MDB would not have been detected and publicly exposed... Instead of responding to the issues raised, the law enforcement agencies are arresting and shutting the whistleblowers down. (Emphasis added.)

But really all that and more had failed to intimidate some - and among these people were the two brave souls: a former Umno division leader Khairuddin Abu Hassan and his lawyer Matthias Chang. In all probability the trials and tribulations of the two started in December 2014 with Khairuddin filing a police report against $1 \mathrm{MDB}$.

\subsubsection{Khairuddin and Matthias}

In a news report filed in the Free Malaysia Today on the very same day that Khairuddin had lodged his police report which was December 12, 2014, the following was mentioned early on (Amin, 2014): "Batu Kawan Umno deputy chief Khairuddin Abu Hassan, in a report made at the Dang Wangi police station, gave a list of what he said were "questionable" business, investment and fund raising transactions and decisions." And later at the end of the news report, the following heading in bold plus the rest appeared:

\section{The report urges the authorities to look into the following, among other things:}

- The procedures $1 M D B$ follows in raising funds from overseas and in disbursing its funds

- The question of $1 \mathrm{MDB}$ paying interest at rates higher than the market rate

- The question of $1 \mathrm{MDB}$ paying fees to Goldman Sachs International that are considered exorbitant

- The less-than-transparent parking of funds overseas, specifically in the Cayman Islands

- Petaling Jaya Utara MP Tony Pua's statement that the Finance Ministry had issued a letter of support to guarantee 1MDB's loans and Deputy Finance Minister Ahmad Maslan's subsequent assertion that no such letter had been issued

- The workings of 1MDB subsidiaries, 1MDB Global Investments Ltd and 1MDB Energy Ltd 
- The purchase of energy assets from Powertek Energy and Sanyen Power Sdn Bhd at prices higher than the market price

- The purchase of 234 acres of land in Air Itam at RM1.38 billion, which will be hard to recover from the proposed housing projects

- The US\$1.2 billion investment in PetroSaudi International Ltd, which was done without transparency

- The purchase of land from Tadman Resources Bhd in Pulau Indah for RM317 million

- The purchase, at a premium price, of the site for the Tun Razak Exchange project.

The next day in a news report by The Malaysian Insider, the following was mentioned ("1MDB says welcome any probe", 2014):

Penang's Batu Kawan Umno division leader Khairuddin Abu Hassan lodged the police report at the Dang Wangi district police headquarters in Kuala Lumpur, saying he was "suspicious" and doubted the financial management of $1 \mathrm{MDB}$, which he noted was not transparent. Calling for a "detailed and comprehensive" investigation, Khairuddin urged authorities to interrogate $1 \mathrm{MDB}^{\prime}$ 's directors, and representatives of any company that might be implicated. He said he lodged the report against the company and its board of directors after studying various reports in national and international print media and online media that "clearly proved" that there were weaknesses in 1MDB's management of taxpayers' funds. 1MDB also failed to be convincing in countering these allegations of impropriety, he said.

In the same news report Khairuddin was quoted to say: "As a responsible citizen, I am anxious and worried over the very opaque manner of 1MDB's management of its funds. As of March $2014,1 M D B$ is burdened with debts to the tune of RM41.9 billion, bearing the risk of bankruptcy and the loss of public funds. This will burden the Malaysian government as 1MDB's guarantor." And the response from $1 \mathrm{MDB}$ came swiftly in the form of press statement issued on the very night following the filing of Khairuddin's police report some hours earlier. The very same The Malaysian Insider news report which quoted Khairuddin above had this stated out coming from the 1MDB's press statement:

We are aware that a police report concerning $1 \mathrm{MDB}$ was filed earlier today by a politician in Penang. We have not seen any documentation related to this, so are unaware of the nature of the complaint. However, we are confident that it will have no legal basis. We welcome any investigation into our affairs and the opportunity to rebut malicious allegations.

Two days later in another news report in The Edge Financial Daily Khairuddin had denied that he was involved in a conspiracy in Umno to topple the then prime minister (Sue-Chern, 2014b). Related to this, he was quoted to say:

I have spelt out very clearly [before]. I acted alone based on my own principles... I stand alone in this... The public outcry has gone on for too long. There have been many queries from the public, the opposition and even three former finance ministers. Reports in business newspaper The Edge had also pointed out these issues. But 1MDB just kept mum. It denied nothing. Just imagine the RM41.9 billion debt recorded by the company. It is a public issue. If anything goes wrong with the board, it will affect the government and in turn, affect the people. Unfortunately, we don't have leaders who would ... question the matter. We have leaders who ... refuse to hear what the people are saying... But my stand is clear. I fight for 
the people. My conscience is clear. We need good governance in government-linked companies.

In February in the following year 2015 Khairuddin's 1MDB trials and tribulations appeared to have begun. Note the following appearing in late March in The Malaysian Insider (Ng, 2015):

In December last year, Khairuddin had lodged a police report against the firm... A month later, he lodged a similar report with MACC, urging the anti-corruption body to look into reports of alleged mismanagement in the sovereign wealth fund. Khairuddin, however, was subsequently sacked from his division post in February, after being declared a bankrupt in May last year by the Malaysian Insolvency Department. It is learnt that his party received a report on his bankruptcy in December.

And in late May 2015, a news report had disclosed the following ("Dr. Mahathir warns BNM", 2015):

Dr Mahathir yesterday also hit out at the authorities' "refusal" to take action on the police reports lodged over 1MDB's "vanished funds". "Instead, the person who lodges the police report is made a bankrupt, his house is seized and he is investigated for allegedly funding terrorism," said Dr Mahathir, referring to sacked Umno leader Datuk Seri Khairuddin Abu Hassan.

Later in September 2015 things got much worse for Khairuddin following a series of two events taking place in the first half of the month: one took place on the $3^{\text {rd }}$ and the other on the $11^{\text {th }}$ of September. First, on September $3^{\text {rd }}$, The Malaysian Insider reported that he had made scathing remarks against the police following the statement made by the then Inspector-General of Police Tan Sri Khalid Abu Bakar that Tun Mahathir would be called for questioning for attending and making statements to the press at the Bersih 4 rally - when all along to Khairuddin's infuriation there had been no action taken on the police report he lodged over 1MDB filed in December the year before ("Ex-Umno leader demands", 2015). The news report had quoted Khairuddin's remarks in his Facebook account:

If Tan Sri Khalid Abu Bakar can make a statement about wanting to call Tun Dr Mahathir Mohamad for attending Bersih 4, why haven't Najib Razak, Rosmah Mansor, Riza Aziz and Jho Low been called up? What is so special about them? Why is PDRM practicing double standards in their investigations? ... What is supposed to be given priority is not investigated. In the end PDRM will have to bear the shame."

The same news report had also mentioned the following:

Khairuddin today took jibes at the police, saying that the stories "created" about how former PetroSaudi International executive Xavier Andre Justo had forged or tampered with documents he stole about 1MDB had been denied by Thai police. The former Umno leader also scoffed at the Malaysian police's request to Interpol to place UK-based Sarawak Report editor Clare Rewcastle-Brown, on its red notice, now that Interpol had rejected the request. Later on September $11^{\text {th }}$, The Malaysian Insider had this mentioned within the first few lines of its news report ("Hong Kong police launch probe", 2015):

Police in Hong Kong have begun investigations into a series of deposits linked to Datuk Seri Najib Razak, after news that RM2.6 billion had been channelled into the prime minister's personal accounts. The Financial Times reported today that Hong Kong police had begun 
probing into bank deposits of over US\$250 million purportedly made at a Credit Suisse branch there... Investigations by Hong Kong authorities were launched after former Umno leader Datuk Seri Khairuddin Abu Hassan lodged a report with Hong Kong police on August 30 regarding troubled state investment firm 1Malaysia Development Berhad (1MDB). Khairuddin, who had been a senior member of Umno until he was sacked this year, said in his report that the deposits had been made through four companies linked to Najib: Alliance Assets International, Cityfield Enterprises, Bartingale International and Wonder Quest Investment.

The same news report had also quoted Khairuddin on what he wrote in his Facebook account:

These companies are highly questionable. I have asked the police in Hong Kong to make a detailed and comprehensive investigation of the companies' financial resources and transactions... I wanted police from another country to investigate comprehensively and transparently and without any influence from the prime minister of Malaysia. Honestly and sincerely, I no longer have trust or confidence in the police, the [central bank] and the Office of the Attorney-General.

And so a week later on September $18^{\text {th }}$ three quite important news report came out in The Malaysian Insider. The first two came out in the late afternoon while the third at night. For the former, one came out just after $4 \mathrm{pm}$ and the other a few minutes before $6 \mathrm{pm}$. In the former, The Malaysian Insider mentioned that Khairuddin had been barred from leaving Malaysia (Md Izwan and KC, 2015). In this regard, he was quoted to say in his Whatsapp: "That's right, I've been barred from leaving the country by the Immigration Department on the orders of Bukit Aman." The same news report has also mentioned several other interesting facts: first that Khairuddin's lawyer, Matthias Chang, a former aide of Tun Dr Mahathir Mohamad, had also been barred from leaving the country and second that in the previous two months of July and August Khairuddin had in fact lodged lodged reports with Hong Kong, British, and French police over 1MDB and finally third that he had submitted evidence related to $1 \mathrm{MDB}$ to the Swiss attorney-general in Switzerland with the request for investigation conducted over the company's activities involving both Swiss and several international banks.

As for the other news report that came out just a few minutes before $6 \mathrm{pm}$ on September $18^{\text {th }}$, it is mentioned that Khairuddin had stated in his Facebook account that he was under investigation for submitting evidence related to 1Malaysia Development Berhad (1MDB) to the Swiss attorney-general in Switzerland and that the police had summoned him for questioning at its headquarters in Bukit Aman, Kuala Lumpur, on the coming Monday ("I'm probed for handing", 2015). And next Khairuddin raised the question in what way that his Swiss's evidence submission had made him to be considered to have gone against the laws. He was quoted to say: "I have the right to lodge reports in any country in this world, on the condition that it is in accordance with international laws." As for the rest of the news report there was the mentioning of among others the following:

He insisted that he had only acted in the country's best interests, and that he had the locus standi to lodge a report with Swiss authorities... He said the investigation against him proved the country's legal system had gone "upside down". But he pledged to cooperate with the police and said he would appear at Bukit Aman on Monday as requested. 
And finally just four hours later and it was already night time by then there was a bomb shell of a news report in The Malaysian Insider that said ("Cops arrest former Umno man", 2015): "Former Umno leader Khairuddin Abu Hassan was arrested by police this evening... Khairuddin, the ex-Batu Kawan Umno division vice-chief, was picked up from his home this evening and was taken to the Dang Wangi district police headquarters. Lawyer Matthias Chang confirmed the arrest." As for what had happened in the next few days, note the following mentioned in a news report by The Malaysian Insider (Nabihah Hamid, 2015a):

Datuk Seri Khairuddin Abu Hassan, who was detained by police under the Security Offences (Special Measures) Act (Sosma), was rushed to the Kuala Lumpur Hospital this evening. Khairuddin... was first arrested by police at his home in Mont Kiara last Friday. Earlier on the same day, he and Chang were barred from leaving the country by Immigration officers at the Kuala Lumpur International Airport. Inspector-General of Police Tan Sri Khalid Abu Bakar had said Khairuddin was detained as his move to use foreign enforcement agencies to put pressure on Malaysia over the 1Malaysia Development Berhad issue could be deemed as an act of sabotage against the country... It was reported that he was on his way to meet Federal Bureau of Investigations (FBI) officials in the United States when he was barred from leaving the country. He was remanded for six days after his arrest on Friday, and on Wednesday, was re-arrested under Sosma just as he walked out of a courtroom at the Jalan Duta court complex where a magistrate had released him. Under Sosma, a suspect can be detained without trial for up to 30 days.

And in the following two weeks until $12^{\text {th }}$ October 2015 when both Khairuddin and Chang were charged in court with attempted sabotage of the Malaysian economy and in particular the financial and banking system it appears as if all hell was let loose! See the following for the headings of a sample of news reports found in theedgemarkets.com during that the two week period:

- $1 M D B$ critic files suit to challenge detention under Sosma (September 28, 2015)

- Cops record Matthias Chang's statement over former Umno leader and 1MDB critic (September 28, 2015)

- Axed Umno leader files suit to challenge detention (September 29, 2015)

- Questioning Matthias Chang is harassment, lawyers group tells cops (September 29, 2015

- Khairuddin objects to one-month request on Sosma hearing (September 30, 2015)

- Sosma worse than ISA, Dr Mahathir says after Khairuddin's arrest (September 30, 2015)

- October 13 court hearing for 1 MDB critic's challenge against anti-terror law (October 2, 2015)

- Khairuddin cleared of dengue, back to Dang Wangi lock-up (October 6, 2015)

- Putrajaya has killed democracy, says Dr Mahathir (October 7, 2015)

- Lawyer Matthias Chang arrested under Sosma (October 8, 2015)

- Malaysian Bar urged to make strong stand against lawyer's detention (October 8, 2015)

- Bar appalled at Chang's detention (October 8, 2015)

- Arrest of Khairuddin's lawyer undermines rule of law, says DAP (October 9, 2015)

- Lawyer Matthias Chang to challenge Sosma detention (October 9, 2015) 
- Clampdown on dissent counter-productive, says Rafidah (October 12, 2015)

- Khairuddin, Chang charged with sabotaging Malaysian economy (October 12, 2015)

- Dr Mahathir, BN leaders criticise Sosma, say used against critics (October 12, 2015)

- Court declines to hear Khairuddin, Chang's application to review charge (October 12, 2015)

- $\quad B N$ veterans join Dr Mahathir in 1 MDB battle (October 12, 2015)

- Haul up opposition if seeking Najib's ouster is a crime, says ex-minister (October 12, 2015)

- Kit Siang urges Umno trio to table motion to condemn Sosma arrests (October 12, 2015)

Why was there much brouhaha against Sosma being used in detaining Khairuddin and his lawyer Matthias? Note the following statement signed by Dato' Akhbar Satar who was and still is the president of Transparency International Malaysia which is an independent, non-governmental and non-partisan organization fighting against corruption (Akhbar, 2015):

Transparency International - Malaysia (TI-M) viewed with grave concern the recent arrest of former UMNO Batu Kawan Division Deputy Chief, Datuk Seri Khairuddin Abu Hassan and his lawyer Matthias Chang... Both Khairuddin and Matthias are now arrested under the Security Offences (Special Measures) Act 2012 (SOSMA). TI-M strongly condemns the use of this law to detain Whistle Blowers without trial. If the police have strong reasons to believe the duo are a threat to national security they should be charged and tried accordingly. Detaining them for 28 days without trial is an abuse of power by the authorities. What has happened to all the government's promises of non-abuse when SOSMA was first introduced? SOSMA was enacted to provide for special measures relating to security offences for the purpose of maintaining public order and security, and for connected matters where action had been taken and further action was threatened by a substantial body of persons. TI-M does not see the nexus between the objectives of the Act and with the detention of Khairuddin and Matthias. (Emphasis was already around.)

In case all that coming from Akhbar Satar on Sosma is not all that clear cut, note what was mentioned in a couple of news reports as to what happened in two different courts on $12^{\text {th }}$ October 2015. In the Sessions Court coming from The Malaysian Insider the following was mentioned (Anbalagan, 2015a):

Former Umno branch leader Datuk Seri Khairuddin Abu Hassan and his lawyer Matthias Chang were charged today with attempting to sabotage the Malaysian economy and the country's financial and banking system. They are accused of committing the offence in France, United Kingdom, Switzerland, Hong Kong and Singapore, between June 28 and August 26 this year. No plea was taken when both were brought before magistrate Siti Radziah Kamarudin, as she has no authority to hear the case since it is a security offence under the Security Offences (Special Measures) Act 2012, or Sosma. Khairuddin and Chang were charged under Section 124L of the Penal Code, which upon conviction carries a jail term of up to 15 years. However, procedures under Sosma will be used instead of the Evidence Act, as this is not considered a normal criminal proceeding... The anti-terrorism law allows for a suspect to be held for up to 28 days after arrest. 
And in the High Court coming from The Edge Financial Daily (V. Anbalagan, 2015b):

The High Court declined yesterday to hear former Umno Batu Kawan division vice-chief Datuk Seri Khairuddin Abu Hassan and his lawyer Matthias Chang's application to review the charge against them for attempted sabotage of the economy. Lawyer Mohamed Haniff Khatri Abdullah said judge Datuk Azman Husin wanted the two accused to file formal applications before the matter was adjudicated. Mohamed Haniff said they would file a notice of motion and affidavits in support of the review application and certificate of urgency on why the matter must be heard without delay... Lawyers appearing for the two are of the view that their clients should not be tried under antiterrorism law procedures... Bernama reported that Khairuddin and Chang were charged in the magistrate's court here yesterday with an attempt to sabotage Malaysia's banking and financial services. Khairuddin, 53, and Chang, 65, allegedly committed the offence at five locations between June 28 and Aug 26 this year. The alleged locations are the office of the French Economic and Financial Crimes Division chief in Paris; Charing Cross Police Station in London; office of the Swiss Attorney-General in Bern; WaiChan Police Station in Hong Kong; and Cantonment Police Headquarters in Singapore.

Having noted all that, do take note too on what was raised in a news report related to a press conference given by the then Attorney General on October 13, 2015 the very next day (Gomez, 2015):

Use of the Security Offences (Special Measures) Act 2012 (Sosma) is not limited to terrorism or terrorists alone, the attorney-general said today in a press conference to address criticism against the use of the law on Putrajaya's critics... Apandi said today when Sosma was first enacted, it listed as security offences those in Chapter VI of the Penal Code (offences against the state) and Chapter VIA of the Penal Code (offences relating to terrorism). In Chapter VI, Section 124L of the Penal Code - the charge against Khairuddin and Chang - is listed as an offence, and was one of seven new offences introduced in the Penal Code in 2012 through the Penal Code (Amendment) Act 2012. The seven are activities detrimental to parliamentary democracy, attempt to commit activity detrimental to parliamentary democracy, dissemination of information, sabotage, attempt to commit sabotage, espionage and attempt to commit espionage... He also said that Section 130A of the Penal Code defined the term sabotage to mean an act or omission intending to cause harm, among others, to the maintenance of "essential services", while the term "essential services" was defined to include banking and financial services.

Anyway, more brouhaha took place during the period between the filing of charge in Sessions Court in October $12^{\text {th }}$ and when the High Court allowed bail for both Khairuddin and Chang on November $18^{\text {th }}$ on grounds the charge was not a security offence. Check out the headings of a sample of news reports found in theedgemarkets.com during that period:

- High Court declines to hear application to review charge (October 13, 2015)

- Sosma not for terrorists alone, says A-G (October 13, 2015) 
INTERNATIONAL JOURNAL OF ACADEMIC RESEARCH IN BUSINESS AND SOCIAL SCIENCES

Vol. 8, No. 12, Dec, 2018, E-ISSN: 2222-6990 @ 2018 HRMARS

- Khairuddin, Chang's review hearing on Sosma on Monday (October 13, 2015)

- Don't drag us into politics, says IGP on Dr Mahathir's statement (October 13, 2015)

- Top cop denies Sosma used against government critics (October 15, 2015)

- Draconian laws the wrong way to fight terrorism, says former Umno man (October 16, 2015)

- Matthias Chang ends hunger strike, vows to continue fight against Najb regime (October 16, 2015)

- Lawyers for duo accused of sabotage to cite A-G for contempt (October 19, 2015)

- How's helping client sabotage of economy, asks lawyer in Sosma case (October 19, 2015)

- Decision on sabotage charge against 1MDB critics goes to Federal Court (October 19, 2015)

- Federal Court to hear constitutionality of charge against Khairuddin next month (October 23, 2015)

- $1 \mathrm{MDB}$ critics refused bail pending Federal Court hearing (October 27, 2015)

- Najib should be charged with sabotage, not 1MDB critic, says Dr Mahathir (November 2, 2015)

- High Court to decide if charge against 1 MDB critic a security offence (November 3, 2015)

- Putrajaya mum on use of Sosma against ex-Umno man, lawyer (November 4, 2015)

As for what exactly happened in court on November $18^{\text {th }}$, note the following mentioned in a news report by The Malaysian Insider (Anbalagan, 2015c): "The High Court today allowed bail for former Umno leader Datuk Seri Khairuddin Abu Hassan and lawyer Matthias Chang who were charged with sabotaging the Malaysian economy, and ruled that it was not a security offence... He released them on RM10,000 bail, and ordered the trial to commence in the Sessions Court." In the same news report, the judge Datuk Mohd Azman Husin was also quoted to say: "They cannot be denied bail and Sosma procedures cannot be used in their trial."

Apparently, the judge had the view that the Parliament had never intended for the charge under section $124 \mathrm{~L}$ of the Penal Code which carries a jail term of up to 15 years upon conviction to be a security offence. Hence, as far as the judge was concerned, the procedures under Security Offences (Special Measures) Act 2012 were not applicable to them. Related to this, and in the same news report, Tun Mahathir who was in court was quoted to say: "I am very glad as I thought there is no case. I always thought there is no case under that law (Sosma). Justice has been done." Nonetheless, as mentioned in another news report by The Malaysian Insider, on that very day the court made a ruling in favour of the duo, the prosecution had filed a notice of appeal (V. Anbalagan, 2015d). In this regard, the deputy public prosecutor Masri Mohd Daud was quoted to say: "The petition will outline the error committed by the High Court for the consideration of the Court of Appeal." What happened next is to be covered in perhaps another case study because as far as the present case study is concerned it would be more relevant to find out what happened when Khairuddin and Chang were released from detention.

First take a note on what came out in a news report by The Malaysian Insider on the very day that Khairuddin was released (V. Anbalagan, 2015e): 
Former Batu Kawan Umno deputy chief Datuk Seri Khairuddin Abu Hassan vowed to continue his "fight" despite his detention since September 8, allegedly for making police reports overseas against the state-owned investment firm 1Malaysia Development Berhad (1MDB). Speaking to the media following his release on bail today, Khairuddin said that "the fight to establish the truth will go on till the end". "The mission will be accomplished " he said soon after he emerged from the Kuala Lumpur lower court register after family members posted bail. Khairuddin, however, declined to elaborate on his "misssion". He said justice had been served...

Later in early December 2015 in another news report in The Malaysian Insider Khairuddin explained the reason behind his lodging reports with (five) foreign authories (Nabihah Hamid, 2015b): "I made seven police reports at the Dang Wangi police station but no action was taken by the police. I made them beginning December 12, 2014 to July this year." And in the same news report there was the revelation that he had gone to the MACC too for the same reason. But not only that no actions had apparently been taken on all the reports he lodged, there were other things happening which had made him decided to go to foreign authorities. As mentioned in the same news report:

Khairuddin, a father of four, said he felt compelled to go to foreign agencies after Putrajaya made changes to its $1 \mathrm{MDB}$ probe as well as the Public Accounts Committee's (PAC) investigation. This followed the removal of Attorney-General Tan Sri Abdul Gani Patail, while heading a special task force investigating 1MDB and the RM2.6 billion channelled into the prime minister's personal accounts. Putrajaya also promoted three PAC members to the Cabinet in a reshuffle, temporarily halting the investigations.

It is notable that when it concerns the cabinet promotion of the PAC members in particular, Khairuddin was quoted to say:

I was perplexed why three PAC members, including Datuk Nur Jazlan, were appointed deputy ministers. Why did Najib appoint them when they were in the midst of their investigation of 1MDB? They should have finished the probe first and then they could accept those posts. They accepted the posts and the PAC investigation stopped, what was the motive? So when there was no action, I was confident that money was being laundered overseas. That is why I went to London, Switzerland, France and all these places to lodge police reports.

After claiming that what he did was to fulfill his responsibility to the country and that it was allowed under the law, he mentioned what appeared to be still another reason behind his move to lodge reports overseas: "I did it to urge the police to investigate the current situation like what the Sarawak Report and The Wall Street Journal reported." And finally to end this writing regarding his one year trial and tribulations due to the 1MDB in a much satisfying note, note the good that he mentioned to have come with his spending two months in prison: "Imprisonment is a process that is part of the struggle. This is the risk that we have to take. I thank God that while I was in jail I did not become weaker but stronger and tougher."

To put in a nutshell the seriousness of the situation brought up by the 1MDB sickening saga by late 2015 and early 2016, check out what was mentioned in The Malaysian Insider in early January 2016 regarding the High Court judge Datuk Mohd Azman Husin who as mentioned above had 
released Khairuddin and his lawyer and who ruled that what they did was not a security offense ("Khairuddin has no problem", 2016):

Last week, Chief Justice Tun Arifin Zakaria clarified that Azman Husin's transfer to Shah Alam High Court was not a punishment for deciding in favour of the duo. Instead, Arifin said Azman was transferred to expedite the disposal of criminal cases. He said there were almost 400 criminal cases pending in Shah Alam and needed the experience of Azman to clear the backlog. Azman, along with 12 other High Court judges or judicial commissioners, were transferred effective Jan 1.

And the seriousness of the 1MDB's troubles that went beyond ringgit and sen impacting people's lives had not only revolved upon Malaysians living in Malaysia for if truth be told the 1MDB's troubles had also impacted certain parties overseas - which by the way is a good reminder to the concerned entities overseas and supranational bodies that they should do all that they can to ensure $1 \mathrm{MDB}$ and the like are to be dealt with much zeal, ingenuity, astuteness and last but certainly not the least smart and long term collaborations to ensure the world does not have to confront such cases as much as possible again. As for those overseas whose lives had been impacted by $1 \mathrm{MDB}^{\prime}$ s troubles, certainly Malaysians and for the matter the rest of the world can never forget one Justo?

What Justo and his love ones had to endure was well depicted in an excellent write up published in the newspaper Guardian in late July 2015 mentioned earlier (Ramesh, 2016):

On 22 June 2015, Xavier Justo, a 48-year-old retired Swiss banker, walked towards the front door of his brand new boutique hotel on Koh Samui, a tropical Thai island... That June afternoon, he was expecting a visit from the tourism authorities to sign off on the paperwork. Instead, a squad of armed Thai police burst through the unlocked door, bundling Justo to the ground. The officers tied their plastic cuffs so tightly around Justo's wrists that he bled on the dark tiled floor. The police quickly moved into his office, ripping out the computers and emptying the filing cabinets. After two days in a ramshackle local jail, Justo was flown to Bangkok and paraded before the media, in a press conference befitting a mafia kingpin... Justo was charged with an attempt to blackmail his former employer...

And in case there are readers who are still in the dark as to why all that and more had happened to him, Justo in just a few words was the person who in 2015 started the unraveling of the 1MDB's mysteries over the previous few years. As to how that did get to happen, note the following coming from the same Guardian piece:

Six months earlier, Justo had handed a British journalist named Clare Rewcastle Brown thousands of documents, including 227,000 emails, from the servers of his former employer, PetroSaudi, which appeared to shed light on the alleged theft of hundreds of millions of dollars from a state-owned Malaysian investment fund known as 1MDB. The documents that Justo leaked have set off a chain reaction of investigations in at least half a dozen countries, and led to what Loretta Lynch, the US attorney general, described last week as "the largest 
kleptocracy case" in US history. According to lawsuits filed last week by the United States Department of Justice (DoJ), at least US\$3.5bn has been stolen from 1MDB.

In the final analysis there is really no difference between victims - local or overseas. We all suffer in one manner or another when terrible things are thrown at us... And in the case of the 1MDB sickening saga it appeared that suffering was all that the tyrants wanted us all to experience - it did not matter who or where we were. We in their eyes were just vermins that had brought them troubles and therefore had to be quieted down no matter what! In relation to this it should be worth pointing out what the Bloomberg Business had mentioned to have taken place over a period of a few months in 2015 ("Malaysia's Najib feels the heat", 2015):

Then on July 19, the Malaysian Communications and Multimedia Commission said it had blocked the Sarawak Report's website in Malaysia for publishing content that could "destabilize the country." Rewcastle Brown said she won't be impeded by the government's action, describing it as the "latest blow to media freedom." In an unprecedented crackdown, Malaysian authorities this year have arrested more than 150 journalists, activists, opposition politicians, and lawyers on sedition charges or under a peaceful assembly act that strictly regulates public protests. One of Malaysia's best-known political cartoonists, who goes by the name Zunar, has been charged with nine counts of sedition and faces up to 43 years in prison. On June 22, Thai police arrested a tattooed Swiss national named Xavier Justo, a former executive at 1 MDB investment partner PetroSaudi International, on the resort island of Koh Samui. Police said they suspected Justo of trying to extort money from PetroSaudi and leaking e-mails about the oil company's dealings with $1 \mathrm{MDB}$. Justo denied the allegations, the Bangkok Post reported. Adding to a climate of fear and tension, the Malaysian police launched an investigation into whether government officials, including central bank personnel, were behind the leaking of documents that allegedly showed 1MDB money turning up in Najib's accounts. The central bank on July 12 denied any impropriety.

By and large, the longer the 1MDB questions were to linger on with no acceptable answers in sight the greater the damages that Malaysia and its people had had to bear with. Examples of such damages may be detected in the headings of a sample of news reports found in theedgemarkets.com as follows:

- Najib secure but Malaysia bruised after global anti-graft group rebuke, say analysts (September 3, 2015)

- DAP wants minister to explain advice to Najib to skip graft conference (September 4, 2015)

- Another two years of Najib, Malaysia will be failed state, says Kit Siang (February 29, 2016)

- Najib critics roll out 'Save Malaysia' campaign against him (March 28, 2016)

- 1MDB drags down Malaysia's corporate governance ranking (September 30, 2016)

- Malaysia slides again in corruption survey (January 26, 2017)

- Penang CM says $1 \mathrm{MDB}$ and Jho Low topics waylay investment missions overseas (July 21, 2015)

- Penang CM: 1 MDB and Jho Low topics do not help investments (July 22, 2015) 
INTERNATIONAL JOURNAL OF ACADEMIC RESEARCH IN BUSINESS AND SOCIAL SCIENCES

Vol. 8, No. 12, Dec, 2018, E-ISSN: $2222-6990$ C 2018 HRMARS

- Tong's Value Investing Portfolio: 1MDB problems spill over to equity market (June 25, 2015)

All in all, with the next lengthiest section attempting to lay out two main possible answers to the question of why the 1MDB goings on happened (forming one of two sections for the Part II of the case study), it is important that what has been delineated in this section on the authorities' intimidation tactics is kept in mind and that the previous two sections are understood for what they are: the idealized corporate governance theory (the first section) and the sickening realities or practices of corporate governance in $1 \mathrm{MDB}$ as represented by myriads of questions over the years (the second section). In other words, to be able to answer the questions that are raised in the very last section of this case study, it is crucial that all of the case study's separate parts are considered together and not separately. In short, the truth or perhaps what could be closer to the truth for the $1 \mathrm{MDB}$ comes in interrelated parts to be considered together instead of disconnected pieces left as they are.

\section{References}

1 Malaysia Development Berhad. (2014, October 30). 1MDB replies to criticism. Retrieved from https://www.theedgemarkets.com/article/1mdb-replies-criticisms

1MDB replies to criticism. (2014, October 31). The Edge Financial Daily. Retrieved from http://www.theedgemarkets.com/article/1mdb-replies-criticisms-0

1MDB says welcome any probe, will rebut 'malicious allegations'. (2014, December 13). The Malaysian Insider. Retrieved from http://www.theedgemarkets.com/article/1mdb-sayswelcome-any-probe-will-rebut-\%E2\%80\%98malicious-allegations\%E2\%80\%99

1MDB. (2015, September 20). 1MDB slams Pua for 'sensationalist' modus operandi. Malaysiakini. Retrieved from https://www.malaysiakini.com/letters/312939

Adam, S. (2018, May 30). Malaysia Asks \$8.3 Billion Question on 1MDB. Here's What We Know. Retrieved from https://www.bloomberg.com/news/articles/2018-05-29/malaysia-asks-8-3billion-question-on-1mdb-here-s-what-we-know

A-G not as sensitive as Malay rulers in smelling 1MDB's wrongdoing, says PAS. (2015, October 16). The Malaysian Insider. Retrieved from http://www.theedgemarkets.com/article/g-notsensitive-malay-rulers-smelling-1mdb\%E2\%80\%99s-wrongdoing-says-pas

Ahmad Naqib, I. (2016, July 22). Opposition lawmakers call for RCl to investigate 1MDB. The Edge Financial Daily. Retrieved from http://www.theedgemarkets.com/article/opposition-lawmakerscall-rci-investigate-1mdb 
INTERNATIONAL JOURNAL OF ACADEMIC RESEARCH IN BUSINESS AND SOCIAL SCIENCES Vol. 8, No. 12, Dec, 2018, E-ISSN: $2222-6990$ C 2018 HRMARS

Akhbar, S. (2015, October 12). Transparency Int 'urges 1MDB officials to immediately comply with Bank Negara's instruction'. Retrieved from http://www.theedgemarkets.com/article/transparency-int-\%E2\%80\%98urges-1mdb-officialsimmediately-comply-bank-negara\%E2\%80\%99s-instruction\%E2\%80\%99

Amin, K. (2014, December 12). Umno leader makes police report against 1MDB. Free Malaysia Today. Retrieved from http://www.freemalaysiatoday.com/category/nation/2014/12/12/umno-leader-makes-policereport-against-1mdb/

Anbalagan, V. (2015a, October 12). Khairuddin, Chang charged with sabotaging Malaysian economy. The Malaysian Insider. Retrieved from http://www.theedgemarkets.com/article/khairuddin-chang-charged-sabotaging-malaysianeconomy

Anbalagan, V. (2015b, October 13). High Court declines to hear application to review charge. The Edge Financial Daily. Retrieved from http://www.theedgemarkets.com/article/high-courtdeclines-hear-application-review-charge

Anbalagan, V. (2015c, November 18). Khairuddin, Matthias out on bail, court rules Sosma not applicable. The Malaysian Insider. Retrieved from http://www.theedgemarkets.com/article/khairuddin-matthias-out-bail-court-rules-sosma-notapplicable

Anbalagan, V. (2015d, December 2). Putrajaya appeals against granting bail to 1MDB critics. The Malaysian Insider. Retrieved from http://www.theedgemarkets.com/article/putrajaya-appealsagainst-granting-bail-1mdb-critics

Anbalagan, V. (2015e, November 18). The fight goes on, says Khairuddin on finding the 'truth' behind $1 \mathrm{MDB}$. The Malaysian Insider. Retrieved from http://www.theedgemarkets.com/article/fight-goes-says-khairuddin-finding\%E2\%80\%98truth\%E2\%80\%99-behind-1mdb

Azam, A. (2015, March 4). My say: Lessons Unlearned. The Edge Malaysia Weekly. Retrieved from http://www.theedgemarkets.com/article/my-say-lessons-unlearned

Barrock, J. (2013a, April 1). Will 1MDB's power acquisitions pay off? Kinibiz. Retrieved from http://www.kinibiz.com/story/issues/12168/will-1mdbs-power-acquisitions-pay-off.html

Barrock, J. (2013b, March 26). 1MDB: Giant ponzi scheme or strategic investment fund? Kinibiz. Retrieved from http://www.kinibiz.com/story/issues/11166/1mdb-giant-ponzi-scheme-orstrategic-investment-fund.html 
INTERNATIONAL JOURNAL OF ACADEMIC RESEARCH IN BUSINESS AND SOCIAL SCIENCES Vol. 8, No. 12, Dec, 2018, E-ISSN: $2222-6990$ C 2018 HRMARS

Barrock, J. (2013c, April 3). Khazanah Nasional vs 1MDB. Kinibiz. Retrieved from http://www.kinibiz.com/story/issues/12594/khazanah-nasional-vs-1mdb.html

Bhattasharjee, R. (2016, January 8). Political turmoil shakes nation. The Edge Malaysia Weekly. Retrieved from http://www.theedgemarkets.com/article/political-turmoil-shakes-nation

Blemin, C. (2014a, October 28). Pua: Disclose recipients of fees for 1MDB paper. The Edge Financial Daily. Retrieved from http://www.theedgemarkets.com/article/pua-discloserecipients-fees-1mdb-paper

Blemin, C. (2014b, November 7). 'Govt did not issue letter of support to 1MDB for its loans'. The Edge Financial Daily. Retrieved from http://www.theedgemarkets.com/article/\%E2\%80\%98govt-did-not-issue-letter-support-1mdbits-loans\%E2\%80\%99

Blemin, C. (2014c, October 30). Finance Ministry to address concerns on 1MDB's debts in Parliament next week. Retrieved from http://www.theedgemarkets.com/article/financeministry-address-concerns-1mdbs-debts-parliament-next-week

Blemin, C. (2014d, November 18). Maslan says sorry for misleading Parliament. Retrieved from http://www.theedgemarkets.com/article/maslan-says-sorry-misleading-parliament

Blemin, C. (2014e, November 12). Opposition lawmakers to cite Maslan for contempt over 1MDB issue at Parliament. Retrieved from http://www.theedgemarkets.com/article/oppositionlawmakers-cite-maslan-contempt-over-1mdb-issue-parliament

Blemin, C. (2014f, November 21). 1MDB to be profitable in FY15, says Ahmad Maslan. The Edge Financial Daily. Retrieved from

http://www.theedgemarkets.com/article/1mdb-be-profitable-fy15-says-ahmad-maslan

Blemin, C. (2014g, December 19). Ahmad Maslan should testify to PAC, A-G over 1MDB's shenanigans, says DAP's Pua. Retrieved from http://www.theedgemarkets.com/article/ahmadmaslan-should-testify-pac-g-over-1mdb\%E2\%80\%99s-shenanigans-says-dap\%E2\%80\%99s-pua

Blemin, C. (2015a, March 17). Enquiry on PetroSaudi deal by previous PAC never disclosed to parliament, says chairman. Retrieved from http://www.theedgemarkets.com/article/enquirypetrosaudi-deal-previous-pac-never-disclosed-parliament-says-chairman

Business Portal of India. (2019). Corporate governance: Concepts and objectives. Retrieved from https://archive.india.gov.in/business/corporate_governance/concept_objectivess.php 
INTERNATIONAL JOURNAL OF ACADEMIC RESEARCH IN BUSINESS AND SOCIAL SCIENCES

Vol. 8, No. 12, Dec, 2018, E-ISSN: $2222-6990$ C 2018 HRMARS

Chee Yuan, C. (2015, August 14). 1MDB: Pua's recycled allegations that have been answered. Retrieved from http://www.theedgemarkets.com/article/1mdb-puas-recycled-allegations-havebeen-answered

Chen, J. (2018, March 1). Corporate governance. Investopedia. Retrieved from https://www.investopedia.com/terms/c/corporategovernance.asp

Chong, C. and Ganesh, V. S. (2014, December 19). 1MDB top brass should clear the air, says Ahmad Maslan. The Edge Financial Daily. Retrieved from http://www.theedgemarkets.com/article/1mdb-top-brass-should-clear-air-says-ahmad-maslan

Chua, T. K. (2015a, February 17). Could someone at 1MDB please answer my questions? Free Malaysia Today. Retrieved from http://www.freemalaysiatoday.com/category/opinion/comment/2015/02/17/could-someoneat-1mdb-please-answer-my-questions/

Chua, T. K. (2015b, April 14). Why wait for auditor report or asking for an independent inquiry? The Malaysian Insider. Retrieved from http://www.themalaysianinsider.com/sideviews/article/why-wait-for-auditor-report-or-askingfor-an-independent-inquiry-t.-k.-chua

Commentary by The Malaysian Insider. (2015a, February 13). Kudos to Dr M and Daim for speaking out about 1MDB. The Edge Financial Daily. Retrieved from http://www.theedgemarkets.com/article/kudos-dr-m-and-daim-speaking-out-about-1mdb

Commentary by The Malaysian Insider. (2015b, April 10). Beyond Dr M's questions lies the issue of trust. Retrieved from http://www.themalaysianinsider.com/malaysia/article/beyond-dr-msquestions-lies-the-issue-of-trust

Cops arrest former Umno man after barring him from leaving country. (2015, September 18). The Malaysian Insider. Retrieved from http://www.theedgemarkets.com/article/cops-arrest-formerumno-man-after-barring-him-leaving-country

Don't use 1MDB debate as excuse to brush off problems, PAS tells Najib. (2015, November 3). The Malaysian Insider. Retrieved from http://www.theedgemarkets.com/article/don\%E2\%80\%99t-use-1mdb-debate-excuse-brushproblems-pas-tells-najib

Douglas, A. (2010, July 1). Opinion: Good governance is good business. Company Director Magazine. Retrieved from http://www.companydirectors.com.au/director-resourcecentre/publications/company-director-magazine/2010-back-editions/july-2010/july/opiniongood-governance-is-good-business 
INTERNATIONAL JOURNAL OF ACADEMIC RESEARCH IN BUSINESS AND SOCIAL SCIENCES Vol. 8, No. 12, Dec, 2018, E-ISSN: $2222-6990$ C 2018 HRMARS

Dr M warns BNM against concealing 'lies'. (2015, May 29). The Edge Financial Daily. Retrieved from http://www.theedgemarkets.com/article/dr-m-warns-bnm-against-concealing\%E2\%80\%98lies\%E2\%80\%99

Ex-Umno leader demands status of police probe into 1MDB, says world laughing at cops. (2015, September 3). The Malaysian Insider. Retrieved from http://www.theedgemarkets.com/article/ex-umno-leader-demands-status-police-probe-1mdbsays-world-laughing-cops

Financial Reporting Council. (2016, April). The UK Corporate Governance Code. Retrieved from https://www.frc.org.uk/getattachment/ca7e94c4-b9a9-49e2-a824-ad76a322873c/UK-

Corporate-Governance-Code-April-2016.pdf

FMT Reporters. (2014, December 14). Pua doubts 1MDB's 'openness' to be investigated. Free Malaysia Today. Retrieved from http://www.freemalaysiatoday.com/category/nation/2014/12/14/pua-doubts-openness-of1mdb-to-be-investigated/

Gomez, J. (2015, October 13). Sosma not for terrorists alone, says A-G. The Malaysian Insider. Retrieved from http://www.theedgemarkets.com/article/sosma-not-terrorists-alone-says-g

Guan Eng: Najib must be held responsible for 1MDB scandal. (2018, May 28). The Edge Financial Daily. Retrieved from http://www.theedgemarkets.com/article/guan-eng-najib-must-be-heldresponsible-1mdb-scandal

Gunasegaram. P. (2013a, April 3). 10 pressing questions for 1MDB. Kinibiz. Retrieved from http://www.kinibiz.com/story/issues/12824/10-pressing-questions-for-1mdb.html

Gunasegaram, P. (2013b, March 28). 1MDB loans to PetroSaudi put nearly RM6 billion at risk. Kinibiz. Retrieved from http://www.kinibiz.com/story/quotes/11725/1mdb-loans-to-petrosaudiputs-nearly-rm6-billion-at-risk.html

Gunasegaram, P. (2013c, April 26). More questions for 1MDB. Kinibiz. Retrieved from http://www.kinibiz.com/story/issues/17502/more-questions-for-1mdb.html

Gunasegaram, P. (2013d, April 24). 1MDB revisited: A new enigmatic name emerges - SRC. Kinibiz. Retrieved from http://www.kinibiz.com/story/issues/16932/1mdb-revisited-a-newenigmatic-name-emerges-src.html

Gunasegaram, P. (2014a, November 5). 1MDB: A renegade that has to be brought under control. Kinibiz. Retrieved from http://www.kinibiz.com/story/tigertalk/118690/1mdb-a-renegade-thathas-to-be-brought-under-control.html 
INTERNATIONAL JOURNAL OF ACADEMIC RESEARCH IN BUSINESS AND SOCIAL SCIENCES Vol. 8, No. 12, Dec, 2018, E-ISSN: $2222-6990$ C 2018 HRMARS

Gunasegaram, P. (2014b, December 29). 1MDB's Lodin answers nothing. Kinibiz. Retrieved from http://www.kinibiz.com/story/tigertalk/131400/1mdb\%E2\%80\%99s-lodin-answersnothing.html

Gunasegaram, P. (2015a, March 5). Too early to clear RM50 bil 1MDB of wrongdoing. Kinibiz. Retrieved from http://www.kinibiz.com/story/tigertalk/150994/too-early-to-clear-rm50-bil$1 \mathrm{mdb}$-of-

wrongdoing.html?utm_source=applet_mkinicom\&utm_medium=web\&utm_campaign=mkinico m

Gunasegaram, P. (2015b, April 29). 10 things 1 MDB should disclose. Kinibiz. Retrieved from http://www.malaysiakini.com/columns/296794

Hazlan, Z. (2012, June 27). PAC fails to obtain 1MDB investment documents. Malaysiakini. Retrieved from https://www.malaysiakini.com/news/202038

Hong Kong police launch probe into US\$250m linked to Najib. (2015, September 11). The Malaysian Insider. Retrieved from http://www.theedgemarkets.com/article/hong-kong-policelaunch-probe-us250m-linked-najib

Husni Hanadzlah appointed 1MDB spokesperson. (2015, May 29). Bernama. Retrieved from https://www.malaysiakini.com/news/300128

I'm probed for handing 1MDB evidence to Swiss prosecutors, says Umno man. (2015, September 18). The Malaysian Insider. Retrieved from http://www.theedgemarkets.com/article/i\%E2\%80\%99m-probed-handing-1mdb-evidenceswiss-prosecutors-says-umno-man

Kaplan Financial. (2013, April 26). Kaplan Financial Knowledge Bank: Theory of corporate governance. $\quad$ Retrieved from http://kfknowledgebank.kaplan.co.uk/KFKB/Wiki\%20Pages/Theory\%20of\%20corporate\%20gov ernance.aspx

Kay Tat, H. (2015a, June 9). The Edge rebuts Arul Kanda. The Edge Financial Daily. Retrieved from http://www.theedgemarkets.com/article/edge-rebuts-arul-kanda

Khairie, H. (2014, December 19). For 1MDB, half-truths can't mask numbers. Kinibiz. Retrieved from http://www.kinibiz.com/story/tigertalk/129491/for-1mdb-half-truths-can\%E2\%80\%99tmask-numbers.html

Khairie, H. (2015, April 13). If 1MDB was public listed... Kinibiz. Retrieved from http://www.kinibiz.com/story/tigertalk/160113/if-1mdb-was-public- 
INTERNATIONAL JOURNAL OF ACADEMIC RESEARCH IN BUSINESS AND SOCIAL SCIENCES

Vol. 8, No. 12, Dec, 2018, E-ISSN: 2222-6990 @ 2018 HRMARS

listed\%E2\%80\%A6.html?utm_source=applet_mkinicom\&utm_medium=web\&utm_campaign= mkinicom

Khairuddin has no problem with new judge hearing case, says lawyer. (2016, January 11$)$. The Malaysian Insider. Retrieved from http://www.theedgemarkets.com/article/khairuddin-has-noproblem-new-judge-hearing-case-says-lawyer

Kinibiz. (2013, March 26). Multi-billion ringgit unanswered questions over 1MDB. Retrieved from http://www.kinibiz.com/story/issues/13474/multi-billion-ringgit-unanswered-question-over$1 \mathrm{mdb} . \mathrm{html}$

Kit Siang, L. (2014a, November 22). Najib should not set bad example to other Ministers by using threat of legal suit against Tony Pua to evade accountability and should make Ministerial statement to answer teeming questions on 11 aspects of the multi-billion ringgit

1MDB scandal in Parliament on Monday. Retrieved from https://blog.limkitsiang.com/2014/11/22/najib-should-not-set-bad-example-to-otherministers-by-using-threat-of-legal-suit-against-tony-pua-to-evade-accountability-and-shouldmake-ministerial-statement-to-answer-teeming-questions-on-11-aspec/

Kit Siang, L. (2015a, June 3). 10 Questions on 1MDB for dummies for Cabinet Ministers at their meeting today. Retrieved from https://blog.limkitsiang.com/2015/06/03/10-questions-on$1 \mathrm{mdb}$-for-dummies-for-cabinet-ministers-at-their-meeting-today/

Kit Siang, L. (2016, January 9). Who are you bluffing, Apandi? Malaysiakini. Retrieved from https://www.malaysiakini.com/news/326090

Mahathir, M. (2015a, April 23). 1MDB. Retrieved from http://chedet.cc/?p=1672

Mahathir, M. (2015b, June 18). The 1MDB reply. Retrieved from http://chedet.cc/?p=1765

Mahathir, M. (2015c, December 3). 1MDB clarifies. Retrieved from http://chedet.cc/?p=1931

Malaysia turning into police state according to Putrajaya's script, says Suaram. (2015, December 9). The Malaysian Insider. Retrieved from http://www.theedgemarkets.com/article/malaysiaturning-police-state-according-putrajaya\%E2\%80\%99s-script-says-suaram

Malaysia's Najib feels the heat as state-owned 1MDB melts down. (2015, July 22). Bloomberg Business. Retrieved from http://www.theedgemarkets.com/article/malaysias-najib-feels-heatstate-owned-1mdb-melts-down

markets 
INTERNATIONAL JOURNAL OF ACADEMIC RESEARCH IN BUSINESS AND SOCIAL SCIENCES

Vol. 8, No. 12, Dec, 2018, E-ISSN: $2222-6990$ C 2018 HRMARS

McRitchie, J. (2010, October 24). Corporate governance defined: Not so easily. CorpGov.net: improving accountability through democratic corporate governance since 1995.

Retrieved from https://www.corpgov.net/library/corporate-governance-defined/

Md Izwan and KC, N. (2015, September 18). After lodging reports on 1MDB, duo barred from leaving Malaysia. The Malaysian Insider. Retrieved from http://www.theedgemarkets.com/article/after-lodging-reports-1mdb-duo-barred-leavingmalaysia

Murugiah, S. (2017, March 21). Why has Putrajaya not claimed the US\$1 billion 1MDB's stolen assets seized by US DOJ?, asks DAP's Pua. Retrieved from http://www.theedgemarkets.com/article/why-has-putrajaya-not-claimed-us1-billion1mdb\%E2\%80\%99s-stolen-assets-seized-us-doj-asks-dap\%E2\%80\%99s-pua

Nabihah, H. (2015a, September 25). Khairuddin rushed to hospital, no visitors allowed, says lawyer. The Malaysian Insider. Retrieved from http://www.theedgemarkets.com/article/khairuddin-rushed-hospital-no-visitors-allowed-sayslawyer

Nabihah, H. (2015b, December 2). They ignored my 1MDB reports, so I turned to foreign agencies, says Khairuddin. The Malaysian Insider. Retrieved from http://www.theedgemarkets.com/article/they-ignored-my-1mdb-reports-so-i-turned-foreignagencies-says-khairuddin

$\mathrm{Ng}$, E. (2015, March 25). Police reach out to MACC over Umno man's reports on 1MDB. The Malaysian Insider. Retrieved from http://www.theedgemarkets.com/article/police-reach-outmacc-over-umno-man\%E2\%80\%99s-reports-1mdb

$\mathrm{Ng}$, S. (2016, November 1). If 1 MDB debts not part of federal debts, whose debts are they? Malaysiakini. Retrieved from https://www.malaysiakini.com/news/361169

Ong, A. (2015, May 19). Will PAC probe into 1MDB yield results this time? Malaysiakini. Retrieved from https://www.malaysiakini.com/news/298801

PAC to quiz those linked to 1MDB. (2015, May 4). Retrieved from http://www.themalaysianinsider.com/malaysia/article/pac-to-quiz-those-linked-to-1mdb

Pathmawathy, S. (2011a, November 21). PAC to probe 1MDB-PetroSaudi deal. Malaysiakini. Retrieved from https://www.malaysiakini.com/news/181998

Pathmawathy, S. (2011b, November 21). 1MDB quizzed on Ioan to PetroSaudi. Malaysiakini. Retrieved from https://www.malaysiakini.com/news/182111

Pathmawathy, S. (2012, June 28). Pakatan: 1MDB account 'manipulated' to show profit. Malaysiakini. Retrieved from https://www.malaysiakini.com/news/202186

Pua, T. (2015a, February 8). 1MDB keeps funds abroad when debts overdue? Malaysiakini. Retrieved from https://www.malaysiakini.com/news/288633 
INTERNATIONAL JOURNAL OF ACADEMIC RESEARCH IN BUSINESS AND SOCIAL SCIENCES

Vol. 8, No. 12, Dec, 2018, E-ISSN: $2222-6990$ C 2018 HRMARS

Putrajaya goes to campuses with propaganda book on 1MDB. (2016, February 26). The Malaysian Insider. Retrieved from http://www.theedgemarkets.com/article/putrajaya-goes-campusespropaganda-book-1mdb

Ramakrishnan, S. (2015, July 30). Blind loyalty takes the edge out of 1MDB probe. Malaysiakini. Retrieved from https://www.malaysiakini.com/letters/306693

Ramesh, R. (2016, July 29). 1MDB: The inside story of the world's biggest financial scandal. The Guardian. Retrieved from http://www.theedgemarkets.com/article/1mdb-inside-storyworld\%E2\%80\%99s-biggest-financial-scandal

Revelations by BN spokesman show Najib meddled in 1MDB probe, says Azmin. (2015, August 17). The Malaysian Insider. Retrieved from http://www.theedgemarkets.com/article/revelations-bn-spokesman-show-najib-meddled$1 \mathrm{mdb}$-probe-says-azmin

Sharmila, G. (2015, February 13). Halt the silence, 1MDB. Kinibiz. Retrieved from http://www.kinibiz.com/story/tigertalk/145127/halt-the-silence1mdb.html?utm_source=applet_mkinicom\&utm_medium=web\&utm_campaign=mkinicom

Sue-Chern, L. (2014a, September 25). Guan Eng: Explain 1MDB land deals in Penang. The Edge Financial Daily. Retrieved from http://www.theedgemarkets.com/article/guan-eng-explain$1 \mathrm{mdb}$-land-deals-penang

Sue-Chern, L. (2014b, December 15). Khairuddin: No plot, I acted alone. The Edge Financial Daily. Retrieved from http://www.theedgemarkets.com/article/khairuddin-no-plot-i-acted-alone

Sun, L. (2019). Why is corporate governance important? WebFinance Inc. Retrived from http://www.businessdictionary.com/article/618/why-is-corporate-governance-important/

Tay, C. (2016a, October 24). Former 1MDB spokesman Ahmad Husni now queries Putrajaya on fund's deals. Retrieved from http://www.theedgemarkets.com/article/former-1mdbspokesman-ahmad-husni-now-queries-putrajaya-funds-deals

Tay, C. (2016b, October 25). Ex-1MDB spokesman queries govt on fund's deals. The Edge Financial Daily. Retrieved from http://www.theedgemarkets.com/article/ex-1mdb-spokesmanqueries-govt-fund\%E2\%80\%99s-deals

Tay, C. (2016c, October 25). Shafie Apdal backs Ahmad Husni's query. Retrieved from http://www.theedgemarkets.com/article/shafie-apdal-backs-ahmad-husnis-query 
INTERNATIONAL JOURNAL OF ACADEMIC RESEARCH IN BUSINESS AND SOCIAL SCIENCES

Vol. 8, No. 12, Dec, 2018, E-ISSN: $2222-6990$ C 2018 HRMARS

Tay, C. (2016d, October 31). Finance Minister II: Not wrong to question 1MDB in Parliament. Retrieved from http://www.theedgemarkets.com/article/finance-minister-ii-not-wrongquestion-1mdb-parliament

Tay, C. (2016e, November 4). Mention of 'oath of secrecy' was a mere reminder, says Speaker. The Edge Financial Daily. Retrieved from http://www.theedgemarkets.com/article/mention\%E2\%80\%98oath-secrecy\%E2\%80\%99-was-mere-reminder-says-speaker

Tay, C. (2016f, October 26). Rahman Dahlan slams Husni, Shafie over 1MDB criticism. Retrieved from http://www.theedgemarkets.com/article/rahman-dahlan-slams-husni-shafie-over-1mdbcriticism

Ten questions for 1 MDB chief, Tony Pua says ahead of live debate. (2015, November 3 ). The Malaysian Insider. Retrieved from http://www.theedgemarkets.com/article/ten-questions$1 \mathrm{mdb}$-chief-tony-pua-says-ahead-live-debate

The Edge Malaysia. (2015a, April 3). Cover Story: Shahrol, please explain Good Star, the money $1 \mathrm{MDB}$ paid the company and why you took instructions from Jho Low. The Edge Malaysia Weekly. Retrieved from http://www.theedgemarkets.com/article/cover-story-shahrol-please-explaingood-star-money-1mdb-paid-company-and-why-you-took

The Edge Malaysia. (2015b, June 18). The Potential 1MDB Blowout: Why auditors cannot guarantee there was no fraud at 1MDB. The Edge Malaysia Weekly. Retrieved from http://www.theedgemarkets.com/article/potential-1mdb-blowout-why-auditors-cannotguarantee-there-was-no-fraud-1mdb

United States seeks to recover more than $\$ 1$ billion obtained from corruption involving malaysian sovereign wealth fund. (2016, July 20). Press Release Number 16-839 by the United States Department of Justice. Retrieved from https://www.justice.gov/opa/pr/united-states-seeksrecover-more-1-billion-obtained-corruption-involving-malaysian-sovereign

Why has Najib refused to address Parliament on 1MDB? asks DAP's Pua. (2017, July 26). theedgemarkets.com. Retrieved from http://www.theedgemarkets.com/article/why-has-najibrefused-address-parliament-1mdb-asks-daps-pua

Yeap, C. (2015a, June 4). Thanks 1MDB, now tell us if the RM15.4b is cash or 'units'. The Edge Financial Daily. Retrieved from http://www.theedgemarkets.com/article/thanks-1mdb-now-tellus-if-rm154b-cash-or-\%E2\%80\%98units\%E2\%80\%99

Zachariah, E. (2015a, June 4). Stop giving half-baked answers on RM42 billion debt, Pua tells 1MDB. themalaysianinsider.com. Retrieved from http://www.theedgemarkets.com/article/stopgiving-half-baked-answers-rm42-billion-debt-pua-tells-1mdb 
INTERNATIONAL JOURNAL OF ACADEMIC RESEARCH IN BUSINESS AND SOCIAL SCIENCES

Vol. 8, No. 12, Dec, 2018, E-ISSN: $2222-6990$ C 2018 HRMARS

Zachariah, E. (2015b, June 4). Stop Another Umno lawmaker says Najib must answer Dr Mahathir. The Malaysian Insider. Retrieved from http://www.theedgemarkets.com/article/another-umnolawmaker-says-najib-must-answer-dr-mahathir

Zikri, K. (2016, October 24). 1MDB may haunt BN in future, warns ex-minister Husni. Malaysiakini. Retrieved from https://www.malaysiakini.com/news/360298

\section{Appendix 1}

\section{Various Kinds of Answers from the 1MDB Side}

\section{When the Answers to the Questions Bring in More Questions!}

In April 2013, in the fifth and final part of a series of writing on 1MDB, Gunasegaram had early on noted the following (Gunasegaram, 2013c): So far, strategic development company, 1Malaysia Development Bhd or $1 \mathrm{MDB}$ has released two statements to attempt to answer questions raised in two series of articles in KiniBiz and reports in other publications, as well as statements by opposition politicians." Next, he pointed out the following: "But instead of throwing further light on the activities of 1MDB, which has borrowed some RM20 billion at unfavourable terms and so far has just some RM10.8 billion in energy assets bought at high prices, they raise even more questions." (Emphasis is already on.)

For example, in regard to the US\$3 billion bonds issuance used for investments in strategic and important high-impact projects like energy and strategic real estate and where the then 1MDB chief executive officer Mohd Hazem Abd Rahman in relation to this claiming "[t]his success underlines investor appetite and confidence in the Malaysia-Abu Dhabi partnership as well as in Malaysia as a sustainable growth centre enjoying peace, stability and good governance", Gunasegaram wrote:

The bonds are guaranteed by the government and has the same rating as government bonds, so the question of investor appetite and confidence does not arise. Why were the bond terms not disclosed? Were they issued at such an attractive yield? Why was Goldman Sachs the sole lead for the issue? Besides the energy investments, $1 M D B$ is invested in property where it holds government land for development. What urgency is there to get funding for this when bridging financing can be so easily obtained?

As for what happened next to the proceeds made by the company with the dissolution of the so called 1MDB-PetroSaudi joint venture, Gunasegaram mentioned: "The investments in the 1MDBPetroSaudi venture were redeemed but instead of getting cash, 1MDB extended loans. Why finance PetroSaudi? Why make a convoluted deal before the RM7 billion is realised and who is the party who bought the stake? Again, why the secrecy. 
And when the then 1 MDB CEO boasted that the company had been "... transparent and open about the placement of its funds" since "[t]his was reported in the company's annual return lodged with the Companies Commission of Malaysia", Gunasegaram replied:

The annual return to the Companies Commission is required under law. 1MDB has kept its disclosure to the bare minimum and never made any announcements of the deals as and when they were made. If $1 M D B$ is open and transparent, why did it not announce the deals as and when they were made? And why did it not reveal the terms of its various lendings and borrowings? (Emphasis is already on.)

Related to this and where the then 1 MDB CEO had claimed that the investments in various classes of participating shares in a Segregated Portfolio Company registered in the Cayman Islands were safe and had been "... clearly reported in the company's audited account...", Gunasegaram had this to say:

If it is safe, why can't 1MDB state precisely what are these assets that the US\$2.318 billion or some RM7 billion is invested. Could it not have been brought back so that there will be no need to take yet another US\$3 billion loan under dubious conditions, dubious terms and dubious pricing? Can $1 M D B$ expect any confidence from the public when it is such a closed book and throws no light on its various dealings? (Emphasis is already on.)

On 1MDB's being regretful “... that certain quarters with political agendas have hidden facts to persistently make baseless allegations" on the Cayman Islands' investments, Gunasegaram had shot back the following:

Is it becoming part of a political agenda to ask legitimate and relevant questions about the funding and investments of our very own strategic development company operated and funded with money guaranteed by the federal government?

Is is unreasonable to expect that anyone will be suspicious of money parked in Cayman Islands or Saudi Arabia when it should be contributing to the strategic development of Malaysia? How would keeping money in Cayman Islands be strategic? Destinations such as Cayman Islands and British Virgin Islands are used by many international private funds to hide their operations, obtain tax advantages and operate in jurisdictions which ask few questions.

What business does a sovereign strategic development company have putting a huge part of its assets and operating in such places? Wouldn't anybody be suspicious? (Emphasis is already on.)

And as for the location of the billions of ringgit of investments in Cayman Island and nowhere else, Gunasegaram argued: "Surely $1 M D B$ is not saying that there is no other way to invest in reputable funds. They operate all over the world. Is it because it makes it much more difficult to track its activities? As a sovereign fund, there are no tax advantages for operating in Cayman Islands because 1MDB pays no tax. Something does not compute."

Finally, as for the remark that the company was "... government-owned and supported but driven by private sector thinking and practices", that "[i]t strives to fulfill the aspiration of the government with the agility of the private sector" whereby "[b]onds raised are part of capital for the strategic initiatives it undertakes" and that "[a]s a prudent government owned entity, 1MDB considered all of its options (pricing, structure, investment bank, and others) in the recent financing and chose the optimal path in light of the various considerations" which was specifically 
"... a private placement to ensure the timely completion of this economic initiative", Gunasegaram without mincing his words had this to say:

Really? If it was the private sector and if $1 M D B$ had mispriced its bonds the way it has, its entire management and board would have been sacked and taken to task. If it is prudent, why have a sole manager? If it is prudent, why not get the best price from the market via bidding? If it was prudent, why did not $1 M D B$ release a list of those who obtained the bonds? Why was there a hurry via private placement when bridging finance was always an option for property development and even the energy acquisition? All of 1MDB's financing requirements could have been done locally where there is much liquidity. Why was it not?

Over one and a half years later, in late December 2014, P. Gunasegaram did another demolition work - this time when it concerns the press statement which the 1MDB chairman Lodin Wok Kamaruddin had issued on December 23, 2014. Calling himself "Tiger", note the following that come early on in P. Gunasegaram's devastating piece (Gunasegaram, 2014b): "Tiger is appalled at the misinformation that 1Malaysia Development Bhd (1MDB) chairman Lodin Wok Kamaruddin has dished out, claiming he is answering questions posed by the press. It's just a masquerade... he answers nothing... It was a crafty piece of work, using half-truths to mask the shenanigans taking place at 1MDB..." Next, two examples of P. Gunasegaram's demolition work are provided.

First, check out his response regarding Lodin's remark that all of the company's debts were backed by solid assets:

Solid assets? Initially some RM 7 billion were put into Petro Saudi for some Caspian Sea investment and then taken out, and then put into vague investments in Cayman Islands. Most of the money is overseas in indeterminate investments. What kind of strategic investing is that? And then it used over RM11 billion to buy power assets, all of them from Malaysian companies with some of the power asset concessions to expire not long from the time of purchase. It overpaid for these assets giving the sellers massive extraordinary gains. And out of total debt of some RM37 billion, some RM23 billion are in cash or near cash items. Why borrow and then keep over half of your assets in cash? Most are in liquid assets. Why? These are just some of the questions Lodin has yet to answer. (Emphasis is already on earlier.)

As for the second example, it concerns Lodin's remark that in order to ensure that 1MDB maintained a strong liquidity position with a truly diversified global portfolio, some RM7 billion 1MDB funds were invested in a 1 MDB subsidiary that was registered in the Cayman Islands, P. Gunasegaram blasted:

Come, come now, are you taking us for fools? You can invest your portfolio funds from anywhere and you can hedge these funds (at a price of course) to avoid foreign exchange risks. You don't have to be in Cayman Islands to have a truly diversified global portfolio of funds. You can be in Kuala Lumpur. More questions: What benefit comes to Malaysia from making portfolio investments overseas with borrowed funds for which you are already paying $6.71 \%$ in interest costs? Should this not be done by sovereign funds? At your 
INTERNATIONAL JOURNAL OF ACADEMIC RESEARCH IN BUSINESS AND SOCIAL SCIENCES

Vol. 8, No. 12, Dec, 2018, E-ISSN: 2222-6990 @ 2018 HRMARS

admission you are not a sovereign fund, you are a strategic company. So why are you doing this? (Emphasis is already on earlier.)

2. When the Answers had to be Retracted with an Apology Ensued Next...

As Blemin (2014b) mentioned:

The Edge weekly revealed in its cover story dated Oct 24 to Nov 2 that the government had provided a "letter of support" for 1MDB's unit 1MDB Global Investments Ltd to borrow US\$3 billion in March 2013. The letter, dated March 14, 2013, stated that "the government of Malaysia hereby confirms and undertakes to provide the necessary financial assistance to the issuer" in the event the issuer is unable to meet its payments. The guarantee is valid through March 19, 2023.

But guess what had happened next? In late October 2014, the then deputy finance minister Datuk Ahmad Maslan claimed that the finance ministry would be addressing the issues that had been raised by the opposition on 1 MDB's debts early the following month when the ministry did the rounding up of the budget debate (Blemin, 2014c). And so on November 6, 2014 he mentioned in the parliament that the government did not issue any letter of support to 1Malaysia Development Bhd (1MDB) for its loans. Specifically, he was quoted to say (Blemin, 2014b):

I want to stress that the government had only given an explicit guarantee for a 1MDB sukuk for a sum of RM5.8 billion compared to 1MDB's total debt of RM36.25 billion. There is no such thing as mentioned by the MP (Tony Pua) of a letter of support. That is all that has been guaranteed by the government. $1 \mathrm{MDB}$ did not get any [other] guarantee from the government for any other loans

And it appeared that Ahmad's stance came about from the discussion that he had with 1MDB's chief executive officer and chief financial officer. Nonetheless, two days later in a statement dated Nov 8, 2014, Ahmad Maslan had admitted that the government had issued a letter of support to 1 MDB for its loans (Blemin, 2014d)!

In consequence, a few days later, it was reported that the opposition lawmakers had come out with a plan to table a motion in parliament to cite Ahmad Maslan for contempt over the 1MDB issue. Specifically, the following was mentioned in that very report (Blemin, 2014e): "PKR Member of Parliament for Pandan, Rafizi Ramli, said the party felt that Ahmad should be held responsible to the house and people for his statement in Parliament last Thursday that there was no letter of support for 1MDB as earlier stated by Petaling Jaya Utara MP Tony Pua."

At the end, a week after the plan for the contempt motion was mentioned, the following was disclosed in a news report (Blemin, 2014d): “Deputy Finance Minister Datuk Ahmad Maslan today apologised for misleading Parliament in his statements made last week that the government did not issue a letter of support to 1Malaysia Development Bhd (1MDB) for the sovereign fund to raise US\$3 billion (RM9.6 billion) in bonds." Specifically, he was quoted to say: "I admit to the error of the ommission of six words that had led to the confusion. I had no intention to confuse the Dewan. What is good comes from Allah and the weak from his servants. Sorry and thank you."

\section{When the Answers were Proven to be Shamefully False...}

It was again the deputy finance minister Datuk Ahmad Maslan whose remarks in November 2014 had led to much resentment from others. Specifically, in November 2014, he was reported to 
have said that the $1 \mathrm{MDB}$ would continue to spend on its corporate social responsibility (CSR) projects (which had amounted to close to RM400 million since it started operation in 2009) as the sovereign fund was expected to be profitable in its current financial year ending March 31, 2015 (in comparison to the incurrence of net loss amounted to over RM650 million in the year before) (Blemin, 2014f). Believing that the company was being managed by responsible and credible directors, he urged the media to give fair coverage to the company which "lately" was facing too much negative publicity.

About a month later, in response to the Umno division deputy chief Datuk Seri Khairuddin Abu Hassan's move to lodge a police report against the company and its board of directors as noted earlier, Ahmad Maslan was reported to have mentioned that there was nothing to be worried about the 1MDB (Khairie, 2014). In the same write up, he was also quoted to have said: "They only recorded losses last year. I am sure the company has no big problems except for the negative perception made by the police report... Based on my scrutiny and meetings with the CEO, there is nothing worrying about the company."

And with such mind boggling remarks, it is not surprising that there emerged devastating responses from those who were in the know. Two are mentioned here: Khirie Hisyam from KiniBiz and the parliamentarian Tony Pua. From Khairie Hisyam the following was mentioned early on in his quite damaging reposte (Khairie, 2014):

But here's the issue with the deputy minister's statement: there are real problems at 1MDB and they are not, by any measure, simple perception. On the face of it, yes, 1MDB had posted profit for four consecutive years before sinking into red for the latest financial year ended March 2014 (FY14) on the weight of higher borrowing costs. However, here's a couple of questions for Ahmad Maslan: What sort of profit were there in the four financial years spanning FY09-FY13 - paper profit or real profit? Would there had been 'profit' at all had paper gains from annual property revaluation, an unusually high frequency of assets revaluation at that, not offset real losses year after year? Bear in mind that these come from $1 \mathrm{MDB}^{\prime}$ s own accounts filed to the Companies Commission of Malaysia (CCM). In other words, the information does not get any more correct that that.

Right after noting all that, Khairie pointed out the various debilitating deals which 1MDB had got itself entangled with in its few years of existence:

Paper gains aside, continuously posting real losses year after year would rank as a big issue at any company, let alone a state investment fund such as 1MDB. Not to mention other issues such as $1 \mathrm{MDB}^{\prime}$ s huge debts amounting to RM41.9 billion in FY14, according to its accounts, rising $15.7 \%$ from FY13. The debt figure is worrying because 1MDB had proved to be facing difficulties in servicing its debt obligations, restructuring its RM5.5 billion bridging loan from Maybank Investment Bank in 2012 multiple times. This had in turn delayed the fund's proposed listing of its power assets. While we are on the subject, recall that 1MDB grossly overpaid for said power assets while giving Middle-East investment entity Aabar Investments PJS an option to take up as much as $49 \%$ in 1MDB's power holding company Powertek Investment Holdings. 1MDB later paid RM833 million to cancel said option.

As if he could not help himself from giving out some more angry reply, Khairie continued: 
As for investments, 1MDB made a sad 3.26\% return on investments worth RM13.4 billion in FY14 in various places worldwide, a figure which include RM7.7 billion parked in a structured investment company called a Segregated Portfolio Company (SPC) based in the Cayman Islands, managed by Hong Kong-based Bridge Partners. Recall that 1 MDB previously disclosed that it has little control over the Cayman Islands investment, funds of which it intends to bring back into the country by year-end. For returns similar to fixed deposit earnings 1MDB might as well have not bothered with going overseas. Worse, $1 \mathrm{MDB}$ is sitting on a cashpile of RM4 billion that is earning it an even sadder interest of $0.7 \%$ compared to borrowing costs ranging from $5 \%$ to as high as $18 \%$ per year. These issues and more had been raised by KiniBiz and various other observers multiple times, backed by data and numbers from 1MDB's own accounts.

And finally in the last few lines of his retort, Khairie mentioned:

Behind these figures of course, are questionable decision-making on the part of 1MDB itself, a strange thing to consider given Ahmad Maslan's claim today that $1 \mathrm{MDB}$ has a responsible board advised by renowned advisers. Why then did 1 MDB decide to get short-term loan for long-term investments, for one, resulting in trouble meeting loan obligations? As another example why then did 1MDB decide to spend RM382 million in charity when it is still bleeding money, apparently getting priorities mixed up? The biggest concern is that despite all these figures from 1MDB's own accounts, Ahmad Maslan again stated today that $1 \mathrm{MDB}$ is doing fine.

On the very same day that that very piece by Khairie Hisyam appeared in KiniBiz, the parliamentarian Tony Pua as reported in another publication had responded to Ahmad Maslan's remarks noted above with the statement that Ahmad Maslan should testify to the Parliamentary Public Accounts Committee (PAC) and an audit by the Auditor-General (AG) to dispel all accusations of alleged financial shenanigans and impropriety of the 1MDB (Blemin, 2014g). Next, he was quoted to say: "If not, then clearly the Deputy Finance Minister is just putting up a fake front to hide the real truths behind the RM42 billion 1MDB scandal." Note too the following two lines appearing among so many lines in the news report right after that very quotation:

Pua had accused Ahmad for being "the worst possible candidate with the least credibility" to be assigned to defend the besieged $1 \mathrm{MDB}$ and for believing in 1MDB's innocence, as Ahmad had recently asked $1 \mathrm{MDB}$ to clear the air with the public over the various controversies... Ahmad's reputation is already in tatters, after being forced to apologise and retract his answer in Parliament where he denied the existence of a US\$3 billion "letter of support" issued to secure a loan for $1 \mathrm{MDB}$, he added.

In regard to the 1MDB's profits over the years used by Ahmad Maslan to support the argument that the $1 M D B$ was doing just fine, Tony Pua was reported to have mentioned in the same news report that the 1MDB from 2010 to 2013 was in actuality posting consecutive losses of RM236 million, RM273 million, RM526 million and RM1,964 million - but these were hidden from the income statements because of some repeated revaluations of the company's assets in the balance sheets. As mentioned in the news report:

In 2010, 1MDB made a "profit" of RM424 million on the back of a revaluation of its unlisted shares in joint venture investment of US\$200 million (RM660 million)... Subsequently, 1MDB 
recorded paper profits of RM544 million, RM44 million and RM778 million on the back of revaluation of its properties of RM827 million, RM570 million and 2,736 million respectively in 2011, 2012 and 2013... these properties were [earlier] acquired at rock-bottom prices from the federal government.

As for what happened for the financial year 2014, Tony Pua had this to say: "Even in 2014 when it reported losses of RM665 million, that was despite recording a property revaluation of RM897 million. This means that without the revaluation, 1 MDB would have lost another RM1,562 million." To sum it all up, Tony Pua had this to say: "In total over the five years, 1MDB which has taken more than RM42 billion to date, has incurred a staggering cumulative loss of RM4.56 billion."

Note that in the very same piece of writing, it was mentioned that Pua had pointed out that back in November 2014, Ahmad had attempted to assure the Parliament that 1MDB was in good financial health by claiming that the company had "never missed a debt repayment deadline" and was "financially strong". But the truth was that the company on November 30, 2014 had not for the first time missed the deadline to repay a RM2 billion outstanding debt and had in consequence asked for a further extension from the financiers - this was because that very sum "... was part of a debt which was due in November 2013 which has already been restructured and extended multiple times."

Next, Pua claimed that "... despite being awarded a RM11 billion coal-fired power plant project located at Negeri Sembilan in February 2014, 1MDB has failed to kick-off the project because it doesn't have any funds to do so." Related to this, Pua was quoted to say: "Worse, the "financially strong" $1 \mathrm{MDB}$ is practically insolvent without the injection of new funds because it is now unable to execute the multi-billion ringgit projects it has secured from the government." And finally in the very last line of the write up there was the revelation coming from Tony Pua that the attempt by the 1MDB in November 2014 to raise RM8.4 billion had failed and needed to be postponed most probably due to the reluctance of investors and financial institutions to lend more money to the company.

\section{When Even the Former 1MDB Spokesperson Himself Later on When he was no longer part of the Federal Cabinet had to ask Some Quite Basic Questions!}

It was in late May 2015 that the federal cabinet had appointed the second finance minister Datuk Seri Ahmad Husni Hanadzlah as the government's spokesman on matters pertaining to the 1MDB ("Husni Hanadzlah appointed", 2015). In the same report, it was also stated that the appointment of a spokesman was made to avoid contradictions in statements issued on the issue. But what happened one a half years later? Following his quitting the job as the minister in late June the same year (after finding out that he would be transferred to a different ministry in a cabinet reshuffle), within the last week of October 2016 in the parliament, he raised multiple questions relating to $1 \mathrm{MDB}$. As reported in the Malaysiakini (Zikri, 2016):

... he asked why $1 \mathrm{MDB}$ was formed, and if any action would be taken against 1MDB's management for channeling the investment firm's funds to the "wrong places". He also wants to know why the government is only getting full payment for the 60 percent sale of Bandar 
Malaysia by 2020 , instead of immediately. He warned that the government should take the $1 \mathrm{MDB}$ problem seriously instead of pointing fingers and blaming others.

In two other publications one can find more revealing reports. In theedgemarkets.com, it was reported that Husni "urged the government to explain some of 1MDB's more substantial transactions" (Tay, 2016a). For example, in regard to the deal with Abu Dhabi state-owned fund, International Petroleum Investment Co (Ipic), and the latter's subsidiary Aabar Investments PJS, Husni was quoted to say:

What happened to the binding term sheet with Ipic? Why didn't 1MDB fulfil the agreement until Ipic had to file for arbitration to seek US\$6.5 billion, equivalent to RM26 billion, from $1 \mathrm{MDB}$ ? Imagine the financial consequences to the country if we lose (the arbitration) ... If we lose the case, I believe our ratings will fall. When that happens, there will be a systemic effect to our economy. Foreign investment will leave and our economy will slide. Our economy is already deteriorating in terms of business and job opportunity. A lot of companies are closing down, staff are being laid off. This is the reality.

In another publication The Edge Financial Daily on the day after, Tay had also reported the following questions raised by Husni on this matter (Tay, 2016b): "Why did we transfer nearly US\$4 billion into Aabar BVI, which is not owned by Ipic? Why was there no legal action taken against $1 \mathrm{MDB}^{\prime}$ 's management for transferring the money to the wrong firm? Why wasn't any legal action taken against the owners of this firm [Aabar BVI] for this misappropriation of funds?"

And when it concerns the RM4 billion loan provided to former 1MDB subsidiary, SRC International Sdn Bhd, Husni in the very same publication had pointed out the following:

Why did Kumpulan Wang Amanah Persaraan (KWAP) provide a loan of RM4 billion [to SRC], which was allowed a one-off drawdown? Usually, when a loan is provided, drawdown is done progressively, with permission. Further, SRC's principal business is in mining, but only RM400 million was spent on mining, while the rest was used for investments. So another issue here is why didn't KWAP take action since the loan was not used for its intended purpose?

Now, note the following as to why he had to raise all those questions: "I'm not raising these issues for political [mileage]. I just feel that I have the right to know because it will determine my future and our rakyat's future. The prime minister said perceptions determine our survival. These are serious issues; we need to know." Finally, it should be worth noting that right after that very quotation Tay had this mentioned regarding Husni: "He also said it is imperative to have a government with dignity and integrity, one that will apply good governance standards and stay away from political patronage, to ensure that every single sen spent is for the good of the country and its people."

In another write up by Tay appearing in theedgemarkets.com on the very same day, there was quite interesting development taking place. Wrote Tay (2016c):

Sacked former Minister of Rural and Regional Development Datuk Seri Mohd Shafie Apdal lauded the query raised by his ex-colleague, former second Finance Minister Datuk Seri Ahmad Husni Hanadzlah, on transactions by 1Malaysia Development Bhd (1MDB). At Parliament's lobby today, Mohd Shafie told pressmen that it is "disheartening" for the Malaysian government to sell its land to foreigners while only requiring the purchaser to pay 
the full sum of consideration years later... Mohd Shafie, who is also the member of Parliament (MP) for Semporna, Sabah, said he had raised these same issues in Cabinet during his tenure as Minister as well, but some of them went unanswered.

Next, Shafie was quoted to say: "He (Ahmad Husni) was one of the men who knows a lot about 1MDB. We questioned him too in Cabinet, I remember; but some of the questions I asked were not answered. But I am so glad that he came out with that sort of statement. I hope there will be further clarification."

Note that subsequent to Husni's raising his 1 MDB questions in the parliament, Shafie and former deputy prime minister Tan Sri Muhyiddin Yassin had also posted their respective queries on $1 \mathrm{MDB}$ in Parliament. And the outcome was perhaps to be expected! Note the following appearing in Tay (2016d):

Dewan Rakyat's Speaker Tan Sri Pandikar Amin Mulia said these ex-members of Cabinet had breached their oath of secrecy by speaking on issues they had knowledge of during their tenure as ministers. The inspector-general of police Tan Sri Khalid Abu Bakar, on the other hand, also reportedly said the police department has opened investigation papers over the matter and will record statements from three of these former cabinet members for allegedly leaking government secrets.

With such strong reaction coming from the police force, perhaps not surprisingly the then Dewan Rakyat speaker had to make clarification next. And as Tay had reported a few days later (Tay, 2016e): “Dewan Rakyat Speaker Tan Sri Pandikar Amin Mulia has clarified that his comments on former ministers breaching their oath of secrecy was merely a reminder to three leaders who had raised questions about 1Malaysia Development Bhd (1MDB), and not a call to the police to initiate investigations." Next, while saying that in his view the former second finance minister Husni was "not gentlemanly" in expressing disagreement with the government's conduct in parliament after his resignation, he had this to say too:

I am the Speaker, my job is to guard parliament's integrity, not on that (investigation). If the IGP (Inspector General of Police) [has] received reports, then the police have to investigate. Ultimately it will be the court that has to make a judgement, not me... During the press conference last week, a reporter asked me whether three of the former ministers had broken any house rules. I responded that it may not [have been] appropriate for them to do so because they might have broken the oath of secrecy; that was my opinion...

If all this was not bizarre enough, note that a number of interesting disclosures had finally come to public attention when minister in the prime minister's department Datuk Abdul Rahman Dahlan issued statements in reaction to Husni's remarks in the parliament (Tay, 2016f). In particular in regard to the latter's query on why 1 MDB allowed full payment for the sale of a $60 \%$ stake in Bandar Malaysia to a Malaysia-China consortium to be delayed until 2022, Abdul Rahman pointed out that such had been agreed as a result of negotiations taking place under the jurisdiction of none other than Husni himself when he was acting as the second finance minister. Related to this, he was quoted to say: "It is very unbecoming of a finance minister, who led the ministry to negotiate these terms, (to now say) that "I was stupid when I did it... You were the minister in charge, you cannot run away from the responsibility. Don't shoot your own foot..." And when it concerns another former minister Shafie's claim as mentioned above that certain 
questions on $1 \mathrm{MDB}$ that he had posted to the cabinet had been left unanswered during his tenure, Abdul Rahman was quoted to say:

No, 1MDB has given many briefings to the cabinet, where he (Mohd Shafie) was a member of it, and also he was given the Q\&A on the frequently-asked questions... Every single question we asked, were answered. In fact, the one that prepared the booklet on 1MDB was the ministry of finance, and we were given the booklet by Datuk Seri Husni...

Next, as mentioned in the very same news report, Abdul Rahman had pointed out that the back cover of the booklet contained a note by Husni to ministers "whose questions were not answered in this booklet". And it says: "Please feel free to fill up this form, write your questions and deliver it to me, so that I can answer them directly."

Now before another perplexing aspect of the answers provided by the 1MDB side is delineated next there is perhaps a need to find out what members of the general public thought about Husni's query in the parliament. Stephen $\mathrm{Ng}$ whose description mentioned next to his name found below his writing piece as "an ordinary citizen with an avid interest in following political developments in the country since 2008" had this quite devastating thing to say $(\mathrm{Ng}, 2016)$ :

It is nice... to read the prime minister's response to DAP parliamentarian Teresa Kok that 1Malaysia Development Berhad's (1MDB) debts are not part of the federal debts. However, as an ordinary person looking at the $1 \mathrm{MDB}$ scandal, I have many questions to ask Najib Abdul Razak... Some of these questions have also been raised by former second finance minister, Ahmad Husni Hanadzlah. He was trying to work within the system, to help resolve one of the worst financial black holes this country has seen, but he too is frustrated. It is not only the opposition or former prime minister Dr Mahathir Mohamad who are asking these questions, but a member of the ruling party himself has raised these questions that I believe as the man behind the creation of $1 \mathrm{MDB}$ and prime minister of this nation, you had better answer Ahmad Husni. There are no two ways about it. Yet, what was asked in Parliament has also become a case under police investigation, and after listening to Ahmad Husni's speech in Parliament yesterday evening, I do not see any reason for the police to investigate him. He was merely carrying out his duty as an elected representative of the people, and if even he cannot ask questions in the August House, who else can? Najib, this is a parliamentary democracy, not a police state. In my opinion, it is better for you to bow out, than to see the country burn with the debts that 1MDB has created.

After saying all this in a piece replete with various questions involving the $1 \mathrm{MDB}$ and some other relevant matters and which were interspersed with some pointed remarks over one thing or another, Stephen Ng apparently had not had his fill on all that he wanted to say regarding Husni's speech for he had two more things to say. First, not long after saying those quoted above, he mentioned:

If Ahmad Husni's questions cannot be asked, it clearly shows that the government has something to hide. My question is, therefore, is the government working in cahoots with $1 M D B$ in causing billions of ringgit to disappear into a black hole? My apologies if I have to be so blatant, but to know the truth, I have to ask a straight question, instead of beating around the bush. 
And later, at the very end of the piece, he wrote: "If a former minister like Husni who has a Key Performance Index (KPI) exceeding 100 percent has already asked all the right questions in parliament, how can we even trust that you will bring about reform in the country, if you cannot respond to his questions yourself?

Now that what is needed to be said regarding a former minister Husni raising some quite basic questions on $1 \mathrm{MDB}$ has actually been said, it should be interesting to find out the things that he mentioned while he was a cabinet minister acting as the government spokesperson for the 1MDB. By doing so could make the whole thing disclosed above to be more understandable - or perhaps be seen as being much weirder than it already is! When it concerns the former the picture to emerge could be that he was already such a conflicted person while holding the position of the 1MDB spokesperson... Whatever the case may be, it is for the readers to decide for themselves by perusing the news reports with the following headings available at theedgemarkets.com:

- Ahmad Husni: MoF to restructure 1 MDB to avoid systemic risks to M'sia (May 21, 2015)

- Stick with me on $1 M D B$ or resign, Najib tells ministers (June 1, 2015)

- On live TV, Husni avoids giving answers on Jho Low, 1MDB (June 3, 2015)

- Dr Mahathir slams Utusan, minister for misleading public over support for Najib (July 20, 2015)

Note that except for the news report dated June 3, 2015 whose heading gives some interesting picture of what may be found inside, the rest has clearly failed to show the same. But be rest assured that what would be found inside involving Husni among others would be just as interesting as the news report dated June 3, 2015.

\section{When the Answers had Promptly Arrived but the one Answering Came not from the 1MDB or one of the Insiders but Instead an Outsider - from Overseas!}

It was in late May 2018 just a few weeks after the momentous event of the defeat of Umno-BN in the general election of 2014 to be replaced with the new government of Pakatan Harapan that the newly appointed finance minister Lim Guan Eng mentioning in a press release that former prime minister and finance minister Datuk Seri Najib Razak - who was the chairman of 1MDB's board of advisers until it was dissolved in May 2016 and the ministry of finance (MoF) took over its remaining assets - be held responsible and accountable for the 1MDB corruption scandal ("Guan Eng: Najib must be held responsible", 2018).

Apparently the press release had come about to reject the facebook posting by Najib earlier that the payment by the MoF to various parties on behalf of the 1MDB since April 2017 amounted to close to RM7 billion was nothing more than a compensation following the 1MDB's action of transferring all of its real estate assets including TRX and Bandar Malaysia to the MoF as recommended by the Public Accounts Committee (PAC). Instead, as far as Guan Eng was concerned, that very amount plus another amounted to close to RM1 billion that needed to be paid by MoF before the end of 2018 was down right "a major bailout" of the 1MDB. And there is logic behind Guan Eng's argument as seen in the following question which he raised: "Why should the MoF compensate $1 \mathrm{MDB}$ to the tune of tens of billions of ringgit as asserted by Datuk Seri 
Najib Razak, when 1MDB has hardly carried out any development on the land?" And what more was the fact that the issue of compensation by the MoF to the company was irrelevant since "... the transfer of these assets back to the MoF in April 2017 was not a sale and purchase transaction..." As Guan Eng was quoted to have said:

MoF officials have confirmed that no such sale and purchase agreement was executed to the effect. This was consistent with [the] PAC recommendation. The PAC found that 1MDB had neither the financial means, nor the ability to develop, or even to sell these parcels of land. Hence, the MoF needed to take over these projects in order to ensure their continued viability.

In the rest of the news report there were various pointed remarks from him on the unfairness of the various transactions involving the two parcels of land that the federal government and related entities had to face over the years. And all this was concluded with quite a horrifying act at the end! As he put it:

Perhaps most importantly, the RM6.98 billion paid by MoF on behalf of 1MDB was in relation to borrowings completely unrelated to the above real estate projects. The payments were instead made for servicing the coupon interest of RM5 billion 30-year bond issued in 2009. This was mainly used for 1MDB's failed investment with PetroSaudi International Ltd... [The payments were also used for] servicing the coupon interest for US\$3.5 billion worth of 10year bonds issued in May and October 2012. These were intended for the acquisition of power plant assets. These assets have since been disposed of and their proceeds have been completely utilised. However, the bonds remain outstanding in $1 \mathrm{MDB} .$.

Next, Guan Eng had also mentioned that aside from paying for coupon interests for bonds issued in 2009 and 2012, part of the RM6.98 billion was utilised to service the coupon interest for US\$3 billion of 10-year bond issued in March 2013. Related to this he was quoted to say: "The bond was intended to fund the development of [the] TRX. However, the funds raised were never utilised to develop [the] TRX, as reported by the Auditor-General." And as if all this was not horrifying enough Guan Eng had also at the end revealed that out of the RM6.98 billion paid by MoF on behalf of 1 MDB there was a certain amount "... used to repay in full the US\$1.2 billion of advance from Abu Dhabi's International Petroleum Investment Corp. The advance was taken in April 2015 to repay US\$975 million of borrowings from a Deutsche Bank-led consortium."

With all this to be the undeniable facts in regard to the various payments made out by the MoF on behalf of the $1 \mathrm{MDB}$, Guan Eng raised a most penetrating question next: "... why should any returns from the real estate projects - land [parcels] which were originally acquired cheap from the government - be used to cover up the financial holes created by all of 1MDB's other financial misadventures and shenanigans?" He had also claimed the following: "Given all of the above facts and figures, there could be no other description for the RM6.98 billion worth of payments by MoF on behalf of $1 \mathrm{MDB}$ to date, other than to describe it as the single largest bailout in history carried out by the government of Malaysia."

And finally, while saying that the MoF will work with the 1 MDB Special Committee to "recover as much of the lost and stolen funds as possible to plug the debts and deficits created by the Najib administration, and punish those responsible for the worst corruption scandal ever in Malaysian history", Guan Eng had made the proposal to Najib to stop arguing that the close to RM7 billion 
payment was not a bailout by the MoF and instead to give answers to the following three questions:

i. Where has the US\$1.83 billion invested with Petrosaudi International Ltd between 2009 and 2011 gone to?

ii. Where has the US\$3.5 billion raised in 2012 for the purposes of acquiring power plants in Malaysia gone to?

iii. Where has the US\$3 billion raised in 2013 for the purposes of investing in TRX gone to? And believe it or not, the answers had actually come just two days later and were hands down crystal clear. All by the courtesy of financial news and media company Bloomberg headquartered in New York, United States! In its opening, the following was mentioned (Adam, 2018):

Malaysia's new government has wasted no time training its sights on 1MDB, the scandalridden state investment company that's spurred criminal and regulatory probes around the world. Less than a day after taking office, new Finance Minister Lim Guan Eng had ousted premier Najib Razak in his cross-hairs as he spoke of a cover-up of 1MDB's finances. In his latest salvo, Lim asked Najib to explain where $\$ 8.3$ billion raised and planned for certain ventures had "gone to," implying funds may have been misused when the former leader was chairman of $1 \mathrm{MDB}^{\prime}$ 's advisory board.

Next, the Bloomberg piece had this to say: "But answers to Lim's queries can be found in documentation assembled by investigators from Switzerland to the U.S. and Singapore as they probe $1 \mathrm{MDB}^{\prime}$ s links to cases of embezzlement and money laundering." And so in relation to the very first question regarding close to US2 billion invested with PetroSaudi International Limited between 2009 and 2011 had gone to, the following was among others mentioned:

In September 2009, 1MDB agreed to invest \$1 billion in a joint venture with a private oil exploration company, PetroSaudi... investigations showed $\$ 700$ million instead went to one controlled by Malaysian financier Low Taek Jho, who U.S. prosecutors portray as the puppet master behind some of the schemes involving missing funds at 1MDB... When 1MDB decided to exit the venture in June 2010 ... it provided the venture with 830 million in loans over the next year. That brought 1MDB's investment to $\$ 1.83$ billion. Of the additional borrowings, a probe showed $\$ 330$ million went to Low's account. After multiple restructuring agreements on 1MDB's investment in what the U.S. described as "a series of complicated and commercially unnecessary transactions," it ended up with about $\$ 2.32$ billion of units in a Cayman-registered fund which investigators said was a "fraudulent valuation." ... 1MDB later said it redeemed about $\$ 1.4$ billion of fund units, while the U.S. alleges some of it was money from a bank loan which was made to appear like a redemption. On the remaining $\$ 940$ million, a 1MDB director last week told Lim that the company's management failed to supply proof of such holdings over the past two years, and called it a "scam."

As for the amount of $\$ 3.5$ billion raised in 2012 for the purposes of acquiring power plants in Malaysia had gone to, the following was mentioned:

The U.S. Department of Justice alleges Low and 1MDB officials diverted more than 40 percent of the net amount raised, or $\$ 1.4$ billion, to a Swiss bank account belonging to a British Virgin Islands entity known as Aabar Investments PJS Limited or Aabar BVI. The BVI entity bore a 
similar name to Aabar Investments PJS, a unit of an Abu Dhabi wealth fund IPIC which coguaranteed the bonds... Separately, a bipartisan Malaysian parliamentary committee said in 2016 it couldn't verify separate payments totaling $\$ 2.1$ billion to Aabar BVI. 1MDB had said it could be a victim of fraud if payments of $\$ 3.5$ billion intended for IPIC via its unit never made it there.

And finally when it concerns the amount of $\$ 3$ billion raised in 2013 for the purposes of investing in TRX had gone to, the following was noted:

U.S. investigators allege about $\$ 1.3$ billion from the offering was diverted to accounts whose beneficial owner was an associate of Low's... Probes showed that within days of the closure of the bond offering, $\$ 681$ million of the diverted funds were transferred to an account belonging to a Malaysian government official whose description matched Najib's. The former premier has acknowledged receipt of $\$ 681$ million while denying wrongdoing... About $\$ 620$ million was returned to the account belonging to Low's associate in August 2013. Investigators say some of the embezzled funds were used to buy artworks which ended up with Low. The Malaysia-Abu Dhabi joint venture, "which was the stated basis for the 2013 bond sale, was ultimately never funded," the U.S. said. 